MARIA CLAUDETE AFONSO ONOFRE FIORAVANTI

\title{
A APLICAÇÃO DA TECNOLOGIA DA INFORMAÇÃO NO DESENVOLVIMENTO DE PRODUTOS EM PROJETOS AUTOMOTIVOS
}

\author{
Trabalho de Conclusão de Curso \\ apresentada à Escola Politécnica da \\ Universidade de São Paulo, para \\ obtenção do Título de Mestre em \\ Engenharia Automotiva.
}

São Paulo 
MARIA CLAUDETE AFONSO ONOFRE FIORAVANTI

\title{
A APLICAÇÃO DA TECNOLOGIA DA INFORMAÇÃO NO DESENVOLVIMENTO DE PRODUTOS EM PROJETOS AUTOMOTIVOS
}

\author{
Trabalho de Conclusão de Curso \\ apresentada à Escola Politécnica da \\ Universidade de São Paulo, para \\ obtenção do Título de Mestre em \\ Engenharia Automotiva.
}

Área de concentração:

Engenharia Automotiva

Orientador:

Prof. Dr.

Fernando José Barbin Laurindo

São Paulo 
FICHA CATALOGRÁFICA

Fioravanti, Maria Claudete Afonso Onofre

A aplicação da tecnologia da informação no desenvolvimento de produtos em projetos automotivos I M. C. A. O. Fioravanti. -São Paulo, 2005.

$129 \mathrm{p}$.

Trabalho de curso (Mestrado Profissionalizante em Engenharia Automotiva). Escola Politécnica da Universidade de São Paulo.

1.Tecnologia da informação 2.Desenvolvimento de produtos 3.Projeto automotivo I.Universidade de São Paulo. Escola Politécnica. II.t. 

Ao meu marido, amigo e companheiro Alexandre, que têm sido a grande razão do meu crescimento como pessoa e como profissional. 


\section{AGRADECIMENTOS}

Agradeço acima de tudo a Deus pela garra e força de vontade principalmente nos momentos mais difíceis.

Ao meu orientador Prof. Dr. Fernando José Barbin Laurindo pelas importantes recomendações, oportunidades, orientação e apoio, que muito engrandeceram na elaboração deste trabalho.

À Alexandre Fioravanti, meu marido e colega de graduação e mestrado, pelo companheirismo, total incentivo e inestimáveis comentários e sugestões de grande valia para a execução do trabalho.

Aos meus pais Lurdes e Manuel, aos meus segundos pais Darcy e Hilário, as minhas irmãs Carmen e Fernanda e restante família por tudo que me proporcionaram e por saber entender e apoiar ao longo desta jornada.

Aos profissionais da GMB, que colaboraram com experiência, material e paciência, bem como pela ajuda e amizade ao longo do desenvolvimento deste mestrado.

Finalmente a todos, de maneira geral, que, direta ou indiretamente, colaboraram para que esta oportunidade se realizasse. 


\section{RESUMO}

Este trabalho visa analisar a importância da Tecnologia da Informação (TI) no processo de desenvolvimento de produtos em uma indústria automobilística, vislumbrando a melhoria de qualidade, a redução de custo e a otimização do tempo de desenvolvimento em novos projetos, fatores estes considerados de extrema importância para uma indústria automobilística poder competir no mercado nos dias de hoje. O trabalho é iniciado com uma descrição teórica de modelos que analisam o papel da TI, relatando o processo de avaliação de seus benefícios. Também se procura abordar a questão de como a TI influencia a estratégia da empresa, bem como aponta como a informação pode proporcionar vantagem competitiva mediante a este atual mercado. O trabalho é complementado com uma breve descrição dedicada ao processo de desenvolvimento de novos produtos (NPD - New Product Development), focando na responsabilidade deste proporcionar o desenvolvimento de produtos que atendam às expectativas do mercado e que sejam economicamente viáveis para a empresa. Um dos pontos mais importantes deste trabalho é a apresentação, em forma de estudo de caso, da aplicação da teoria abordada sobre a TI no processo de desenvolvimento de veículos na General Motors do Brasil (GMB), expondo seus pontos relevantes e críticos do ponto de vista estratégico. Em seqüência, cabe a descrição da análise do estudo de caso com a finalidade de se avaliar a classificação da GMB sob alguns dos prismas da teoria da TI, a fim de constatar a eficiência e eficácia alcançadas. Por fim, as conclusões encerram este trabalho com colocações importantes do ponto de vista da autora sobre todo o desenvolvimento deste trabalho. 


\begin{abstract}
This work aims to analyze the importance of the Information Technology (IT) in the product development process in an automobile industry, glimpsing the quality improvement, the cost reduction and the optimization of the development time in new projects, which these factors are considered of extreme importance for an automobile industry to compete in the market nowadays. The work starts with a theoretical description of models that analyzes the paper of IT, explaining the process of evaluation of their benefits. Also it tries to approach the question of how the IT can influence the strategy of the company, as well as it shows how the information can provide competitive advantage face to this current market. The work is complemented with a brief description dedicated to the New Product Development (NPD) process, focusing in the responsibility of providing the products development that assist to the market expectations and that are economically viable for the company. One of the most important points of this work is the presentation, through case study format, of the theory application related to the IT in the vehicles development process at General Motors of Brazil, exposing their relevant and critical points under the strategic point of view. In sequence, it fits the description of the case study analysis with the purpose of evaluating GMB classification under some prisms of the IT theory in order to verify the efficiency and effectiveness reached. Finally, the conclusions end this work with important statements under the author's point of view about the whole development of this work.
\end{abstract}




\section{SUMÁRIO}

RESUMO

ABSTRACT

LISTA DE FIGURAS

LISTA DE TABELAS

LISTA DE ABREVIATURAS E SIGLAS

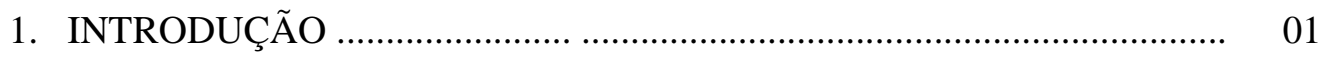

1.1. Relevância do tema ............................................................................ 01

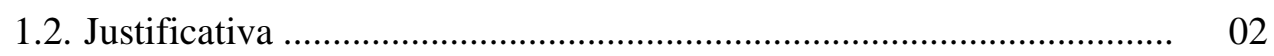

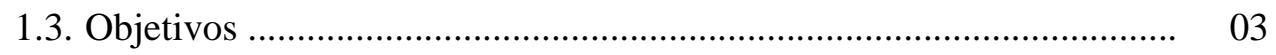

1.4. Estrutura do trabalho ....................................................................... 05

2. O PAPEL DA TI NAS ORGANIZAÇÕES ................................................ 07

2.1. Eficiência e eficácia aplicadas a TI .................................................... 07

2.2. O impacto estratégico da TI .............................................................. 08

2.3. Método fatores críticos de sucesso ................................................... 10

2.3.1. O desenvolvimento e aplicação do método FCS ........................ 14

2.3.2. Comentários sobre o método FCS ............................................ 15

2.4. Análise de como a TI influencia a estratégia ....................................... 18

2.5. Análise de como a informação proporciona vantagem competitiva .... 22

2.6. A cadeia de valor ................................................................................ 23

2.6.1 Transformando a cadeia de valor ........................................... 26

2.7. Matriz de intensidade de informação ................................................. 28

2.8. Modelo do alinhamento estratégico ................................................. 30

2.8.1. Descrição da terminologia do alinhamento estratégico ........... 31

2.9. Escada de avaliação ........................................................................... 45

3. O PROCESSO DE DESENVOLVIMENTO DE NOVOS PRODUTOS DE UMA INDÚSTRIA AUTOMOBILÍSTICA $\ldots$ 
3.1. Conceituação do desenvolvimento de novos produtos ...................... 57

3.2. O NPD ......................................................... 58

3.3. Características específicas do NPD …................................................. 62

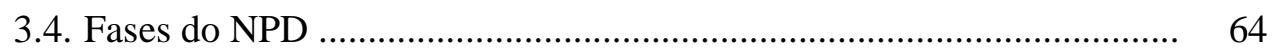

3.5. Dimensões básicas da estrutura referencial para o NPD ..................... 72

3.6. O uso da TI no NPD ......................................................................... 77

4. ASPECTOS METODOLÓGICOS …..................................................... 81

4.1. A “Pesquisa Qualitativa” ................................................................... 81

4.1.1. Características da pesquisa qualitativa .................................... 82

4.1.2. Comparação entre pesquisa qualitativa e quantitativa ............... 83

4.2. O método do "Estudo de Caso" ......................................................... 85

4.2.1. Características do método do estudo de caso ............................. 86

4.2.2. Críticas em relação ao método do estudo de caso ...................... 87

4.3. Proposições do trabalho ..................................................................... 88

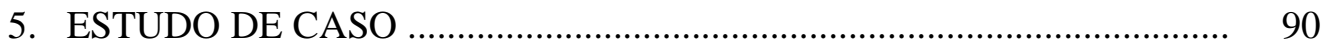

5.1. Otimização do parâmetro “Tempo” ..................................................... 92

5.2. Otimização do parâmetro “Custo” e “Qualidade” ................................ 95

6. ANÁLISE DO ESTUDO DE CASO ……......................................... 110

6.1. Análise quanto ao “Grid Estratégico” e a "Matriz de Intensidade de Informação”

6.2. Análise dos "Fatores Críticos de Sucesso” .......................................... 112

6.3. Análise quanto ao “Alinhamento Estratégico” .................................... 114

6.4. Análise da "Escada de Avaliação” ....................................................... 115

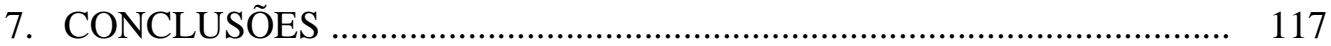

REFERÊNCIAS BIBLIOGRÁFICAS .................................................... 123 


\section{LISTA DE FIGURAS}

Figura 2.1 - Grid estratégico: impactos da aplicação da TI ................................ 09

Figura 2.2 - A cadeia de valor .......................................................................... 24

Figura 2.3 - O sistema de valor .................................................................. 25

Figura 2.4 - A evolução da cadeia de valor com a TI ....................................... 26

Figura 2.5 - Matriz de intensidade de informações ........................................... 29

Figura 2.6 - Modelo do alinhamento estratégico ............................................... 31

Figura 2.7 - Perspectivas da transformação tecnológica e da execução de estratégia

Figura 2.8 - Perspectivas do potencial competitivo e do nível de serviço ......... 37

Figura 2.9 - Perspectiva da execução estratégica ............................................... 39

Figura 2.10 - Perspectiva da transformação tecnológica ................................... 41

Figura 2.11 - Perspectiva do potencial competitivo ......................................... 42

Figura 2.12 - Perspectiva do nível de serviço ..................................................... 43

Figura 2.13 - Perspectivas do alinhamento estratégico ..................................... 44

Figura 2.14 - Escada de avaliação ................................................................ 56

Figura 3.1 - Fatores de influência no projeto ................................................ 58

Figura 3.2 - Modelo de empresa com base no fluxo de informações .................. 60

Figura 3.3 - Interação dos fornecedores no processo de NPD ........................... 62

Figura 3.4 - Ciclo de resolução de problemas ....................................................... 63

Figura 3.5 - Modelo Total Design ................................................................... 66

Figura 3.6 - Setores envolvidos e responsáveis pelas atividades de desenvolvimento

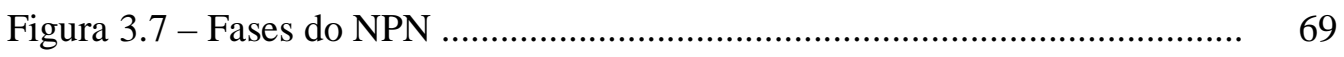

Figura 3.8 - O processo de definição do produto .............................................. 70

Figura 3.9 - Dimensões básicas de uma estrutura referencial para compreensão do NPD

Figura 3.10 - Análise de interferências pelo DMU ........................................... 79

Figura 5.1 - Marcas e alianças da GM ................................................................. 91

Figura 5.2 - Centros de desenvolvimento da GM .......................................... 92

Figura 5.3 - Aplicações paramétricas integradas ............................................... 94 
Figura 5.4 - Redução do tempo do GVDP na GM ......................................... 95

Figura 5.5 - Modelo em "wire frame” ............................................................... 96

Figura 5.6 - Modelo “renderizado” ..................................................................... 97

Figura 5.7 - Sala principal de realidade virtual na GMB ................................ 98

Figura 5.8 - Análise avançada de durabilidade ............................................... 99

Figura 5.9 - Análise avançada estrutural ......................................................... 100

Figura 5.10 - Análise térmica - Fluxo de ar .................................................. 101

Figura 5.11 - Teste de impacto virtual e real ...................................................... 102

Figura 5.12 - Tipos de teste de impacto realizados na GMB ............................ 102

Figura 5.13 - Designação de roteiro para chicote utilizando o DMU ................ 103

Figura 5.14 - Dispositivo construído no DMU ................................................ 103

Figura 5.15 - Análise de formabilidade ........................................................... 104

Figura 5.16 - Análise de ruptura de componentes ............................................ 105

Figura 5.17 - Dispositivo de um ferramental otimizado .................................. 106

Figura 5.18 - Sala de realidade virtual - Engenharia de Manufatura ................. 107

Figura 5.19 - Célula virtual X célula instalada ................................................... 108

Figura 5.20 - Trabalho sem papel na ferramentaria da GMB ........................... 109

Figura 6.1 - Venda de veículos pela “Internet” .................................................. 111

Figura 6.2 - Posição da GMB no “Grid Estratégico” ........................................ 111

Figura 6.3 - Posição da GMB na “Matriz de Intensidade de Informação” ......... 112

Figura 6.4 - Gráfico: “Mão-de-obra X Protótipos Físicos” - GMB ................... 113

Figura 6.5 - Posição da GMB no “Alinhamento Estratégico” .......................... 115 


\section{LISTA DE TABELAS}

Tabela 2.1 - Pontos fortes e fracos do método FCS ............................................ 17

Tabela 2.2 - Características das perspectivas do alinhamento estratégico .......... 44

Tabela 2.3 - Escada de avaliação de benefícios ............................................... 47

Tabela 4.1 - Diferenças entre pesquisa qualitativa e quantitativa ..................... 84 


\section{LISTA DE ABREVIATURAS E SIGLAS}

\begin{tabular}{|c|c|}
\hline ATMs & - Automatic teller machines \\
\hline CAD & - Computer aided design \\
\hline CAE & - Computer aided engineering \\
\hline CAM & - Computer aided manufacturing \\
\hline CAPP & - Computer aided process planning \\
\hline CCB & - Change committee board \\
\hline CNC & - Comando numérico computadorizado \\
\hline DFA & - Design for assembly, projeto conforme requido na montagem \\
\hline DFM & $\begin{array}{l}\text { - Design for manufacturing, projeto conforme requerido pela } \\
\text { manufatura }\end{array}$ \\
\hline DFMEA & $\begin{array}{l}\text { - Design failure mode and effects analysis, análise do projeto (produto) } \\
\text { do modo e efeitos de falha }\end{array}$ \\
\hline DMU & - Digital mock-ups \\
\hline DSS & - Decision support systems \\
\hline ECM & - Engine control module \\
\hline ECM & - Engineering change management \\
\hline EDI & - Electronic data interchange \\
\hline FCS & - Fatores críticos de sucesso \\
\hline GM & - General Motors, utilizando no sentido GM global \\
\hline GMB & - General Motors do Brasil \\
\hline GVDP & - Global vehicle development process \\
\hline IOS & - Interorganizacional systems \\
\hline JIT & - Just in time \\
\hline MEA & - Mestrado em Engenharia Automotiva \\
\hline MIS & - Management information systems \\
\hline NPD & - New product development \\
\hline PDM & - Product data management \\
\hline PFMEA & $\begin{array}{l}\text { - Process failure mode and effects analysis, Análise do processo do } \\
\text { modo e efeitos da falha }\end{array}$ \\
\hline QFD & - Quality function deployment, Desdobramento da função qualidade \\
\hline
\end{tabular}




$\begin{array}{ll}\text { ROI } & \text { - Return on investments } \\ \text { SIG } & \text { - Sistemas de informação gerencial } \\ \text { TcAE } & - \text { Team center Automotive Edition } \\ \text { TI } & - \text { Tecnologia de Informação, IT - Information technology } \\ \text { VOIP } & - \text { Voice Over IP }\end{array}$





\section{INTRODUÇÃO}

\subsection{Relevância do tema}

A forte concorrência no setor automotivo tem levado as empresas a buscar tecnologias que proporcionem o desenvolvimento de produtos com maior rapidez, qualidade e menores custos. Por sua vez, a aplicação estratégica da Tecnologia da Informação (TI) tornou-se um elemento fundamental para o sucesso do processo de Desenvolvimento de Novos Produtos (New Products Development - NPD), conforme entre outros, LAURINDO; CARVALHO (2005).

O NPD encontra-se entre a empresa e o mercado, cabendo a ele proporcionar o desenvolvimento de produtos que atendam às expectativas do cliente, em termos de qualidade, prazos e custos, integrando as áreas da empresa, objetivando produtos economicamente viáveis.

Neste cenário, o papel da TI tem potencial para influenciar a estratégia da empresa, pois contribui tanto para aumentar a sua eficiência como a sua eficácia, proporciona vantagem competitiva no atual mercado, bem como estabelece uma flexibilidade no gerenciamento do projeto, possibilitando virtualmente integrar diversas ferramentas tecnológicas (PORTER, 2001, LEVY; LOEBBECKE; POWELL, 2003 e MAcCORMACK; VERGANTI; IANSITI, 2001).

Por outro lado, a literatura acadêmica de negócios mostra questionamentos acerca dos retornos dos investimentos em TI, o que enseja a importância de estudos que analisem os benefícios da TI em relação aos investimentos estruturais realizados (BRYNJOLFSSON; HITT, 1998).

Sobre a bibliografia pesquisada para a realização deste trabalho, foram encontradas: 
- Alguns livros publicados no Brasil sobre a TI, tanto de caráter acadêmico quanto profissional. Exemplos: LAURINDO, 2002 e TORRES, 1989.

- Muitos artigos internacionais e brasileiros (em anais de eventos e em periódicos) sobre a TI, destacando diferentes métodos de avaliação em diversas aplicações. Exemplos: MENDES, 1987 e LEWIS, P. R.; LUFTMAN, J. N.; OLDACH, S. H., 1993.

- Alguns trabalhos de graduação brasileiros sobre a TI. Exemplo: MARCOVITCH, J., 1996.

口 Vários trabalhos de pós-graduação sobre TI, porém com diversos focos diferenciados. Exemplo: LAURINDO, F. J. B., 2000.

- Muitos livros e artigos, brasileiros e internacionais sobre o processo de NPD, destacando os conceitos e suas características. Exemplos: CLARK, K. B.; FUJIMOTO, T., 1991 e CUSUMANO, M.; NOBEOKA, K., 1992.

\subsection{Justificativa}

A polêmica quanto aos ganhos de produtividade gerados pela TI em detrimento dos significativos investimentos necessários têm levado a alta direção das empresas a questionar sobre a real eficácia da TI na melhoria da qualidade, na otimização do tempo e na redução de custos (CARR, 2003; FARREL, 2003). É o que tem sido chamado de "paradoxo da produtividade" (BRYNJOLFSSON; HITT, 1998).

É sobre a discussão deste paradoxo que este trabalho está estruturado de forma a analisar e verificar que, de fato, existem situações em que as vantagens da aplicação da TI, principalmente no processo do NPD, mostram-se amplamente fundamentais, mas desde que sua aplicação seja feita de forma racional e em alinhamento com as estratégias da empresa. 
A importância do tema deste trabalho pode ser justificada pelos seguintes aspectos:

- Pela carência de trabalhos focados/ concentrados na aplicação da TI no desenvolvimento, manufatura e comercialização de veículos.

• Pela assimilação e análise das melhores práticas e experiências atualmente difundidas e encontradas no dia a dia de uma indústria automobilística;

- Pela necessidade de se avaliar seus pontos fortes fracos quando aplicados em casos reais, bem como o discernimento de análises críticas pertinentes;

Finalmente, por estar diretamente relacionado ao desenvolvimento de produtos, tópico este de grande importância dentro do curso de Mestrado em Engenharia Automotiva (MEA);

\subsection{Objetivos}

O objetivo deste trabalho é analisar a importância da TI no processo de desenvolvimento de produtos na indústria automobilística, através de um estudo de caso em uma montadora brasileira. Para este estudo, foi escolhida a General Motors do Brasil que permitiu a realização deste trabalho, bem como citar seu nome, fornecendo todos os subsídios necessários, no qual se procurou mostrar os ganhos que se possam alcançar em termos de qualidade, redução de custos e otimização de tempo de desenvolvimento, conforme ressaltado acima.

Para este fim, inicialmente é apresentado o papel da TI nas empresas, tendo em vista a eficácia e o aspecto estratégico, através da análise dos diversos modelos apresentados na literatura. Será mostrado também que a TI possui uma natureza altamente dinâmica e evolutiva, interagindo com diversas atividades da empresa e agregando a capacidade de manipulação de expressivos volumes de informações disponíveis aos usuários. 
Também é explanado o processo do desenvolvimento de produtos na indústria automobilística, onde se denota a colaboração de maneira pioneira em relação a outros setores industriais, atuando como impulsionador de novas práticas reduzindo significativamente o tempo de desenvolvimento.

Outro ponto a ser destacado é que o reconhecimento da TI como vital para o processo do NPD é recente e alinhado com a estratégia de se tornar uma fonte de vantagens competitivas, deixando de se caracterizar apenas como um suporte básico ao NPD. Cada vez mais se reconhece a contribuição da TI nas empresas através do lançamento constante de novos produtos caracterizados por serem concebidos em prazos menores, com níveis de qualidade requeridos pelo mercado e com custos reduzidos.

Baseado nos pontos acima, pode-se formular as seguintes perguntas que poderão ser respondidas durante a apresentação do estudo de caso no capítulo 5 deste trabalho, de modo a se poderem comprovar as afirmações anteriores:

- “Como a TI pode apoiar o processo de desenvolvimento de produtos?”

口 "Por que o desenvolvimento de produtos é importante para a indústria automobilística?”

口 Como a TI pode influenciar no parâmetro Tempo no desenvolvimento de um veículo?”

- “Como as variáveis Qualidade e Custo podem ser influenciadas pela TI?”

Visando responder a estas questões, optou-se por uma pesquisa de caráter explanatório, mais especificamente, adotou-se a metodologia do estudo de caso, onde a empresa escolhida apresenta uma combinação de intensificação do processo de lançamento de novos produtos com significativos investimentos em TI para apoiar este processo, sendo ambos os fatores considerados como critérios para selecionar o local da pesquisa de campo. 
Portanto, não é escopo deste trabalho a abordagem pormenorizada de cálculos econômicos/ financeiros que demonstrem matematicamente as vantagens e desvantagens da aplicação da TI, uma vez que, a citação de determinados valores no estudo de caso é restrita e classificada como informação confidencial. Por ética profissional e obedecendo a política da General Motors, de não divulgar ou se tornarem públicas informações confidenciais que possam comprometer os negócios GM. Serão suprimidas tais informações, porém mantendo o escopo da aplicação, a sua situação inicial, trajetória e seus objetivos alcançados, enfocando dentro deste panorama, os objetivos deste trabalho.

\subsection{Estrutura do trabalho}

O presente trabalho está dividido em sete capítulos sendo:

- Capítulo 1: neste capítulo são apresentados os objetivos, a relevância do tema, a justificativa, bem como sua estrutura utilizada no desenvolvimento deste trabalho.

- Capítulo 2: dedicado ao trabalho de pesquisa e revisão bibliográfica, sobre o tópico “O papel da TI nas organizações”, apresentando uma visão geral sobre o impacto estratégico da TI, método e modelos de avaliação da TI nas empresas, bem como a influência da informação na estratégia, proporcionando vantagem competitiva;

- Capítulo 3: também dedicado ao trabalho de pesquisa e revisão bibliográfica, reservado para o processo de desenvolvimento de novos produtos em uma indústria automobilística, procurando demonstrar seu conceito, fases e características;

- Capítulo 4: dedicado aos aspectos metodológicos, abordando o "método estudo de caso", a "pesquisa qualitativa”, bem como o levantamento de proposições;

- Capítulo 5: dedicado especificamente à exposição do estudo de caso, explanando a utilização da TI na GMB, bem como o GVDP é estruturado; 
a Capítulo 6: dedicado exclusivamente à análise do estudo de caso, procurando exemplificar com o método estudo de caso e a pesquisa qualitativa a teoria abordada nos capítulos 2 e 3;

口 Capítulo 7: finalmente um capítulo dedicado às conclusões relevantes e centrais que delineiam o objetivo do trabalho. 


\section{O PAPEL DA TI NAS ORGANIZAÇÕES}

Nos últimos anos, nota-se a rápida evolução e disseminação da TI, isto é, aquela tecnologia que, inclui sistema de informação, processamento de dados, telecomunicações e automação, modificou significativamente as responsabilidades gerenciais. Apareceram novos departamentos, investimentos significativos em hardware e software, treinamentos, etc. Os impactos da TI incidem sobre diferentes áreas funcionais das empresas e também sobre um amplo espectro de indústrias (LAURINDO, 2002; PORTER, 2001; PORTER; MILLAR, 1985).

\subsection{Eficiência e eficácia aplicadas a TI}

Para entender tais impactos da TI é importante distinguir os conceitos de eficiência e eficácia na utilização da TI. Assim entende-se como eficiência no uso da TI a forma de implementar o sistema ao menor custo, desenvolver o sistema de acordo com o levantamento efetuado, usando os recursos da melhor forma possível, no menor tempo e com o melhor desempenho. Assim, se uma empresa, ao adotar uma nova metodologia de desenvolvimento de sistemas, conseguir que haja menos falhas de programação e, portanto melhor qualidade e precisão de resultados, estariam conseguindo aumento de eficiência.

Já a eficácia no uso da TI consiste em implementar ou desenvolver os sistemas que melhor se adaptem às necessidades dos usuários, da área de negócio e da empresa, e que sejam consistentes com a estratégia global da corporação e que melhor contribuam para aperfeiçoar as atividades e as funções desempenhadas pelos usuários e ainda que tragam ganhos em competitividade e produtividade para a empresa.

No âmbito da TI, a eficiência está relacionada com os aspectos internos à realização da atividade, enquanto que a eficácia prende-se ao seu relacionamento com a empresa e os possíveis impactos na sua operação e estrutura (LAURINDO, 2002). 


\subsection{O impacto estratégico da TI}

A obtenção de vantagens requer um amplo gerenciamento dos sistemas de informações, sendo que o processo se torna mais complicado com o fato de que muitos produtos dos sistemas de informações são estratégicos, embora os benefícios potenciais sejam muito subjetivos e não facilmente verificáveis. Freqüentemente, um foco rígido no retorno do investimento (ROI - Return on Investments), por parte da alta gerência, pode voltar a atenção para esses alvos estreitos e bem definidos, em oposição a oportunidades estratégicas mais amplas, que são mais difíceis de analisar (McFARLAN, 1984).

Visualizando a obtenção de vantagens através da TI pode-se utilizar o “Grid Estratégico” com uma das formas de análise do impacto, presente e futuro, da utilização da TI na estratégia e na posição da empresa, no qual tem-se definido quatro quadrantes, cada um representando uma situação para a empresa: suporte, fábrica, transição e estratégico, conforme figura 2.1. McFARLAN (1984). Como critério para identificar impactos estratégicos, o autor considerou eventuais efeitos sobre alguma das cinco forças competitivas: concorrentes existentes, ingressantes potenciais, ameaça de novos produtos, compradores e fornecedores, conforme definição de PORTER (1979). 


\section{MPACTO FUTURO}

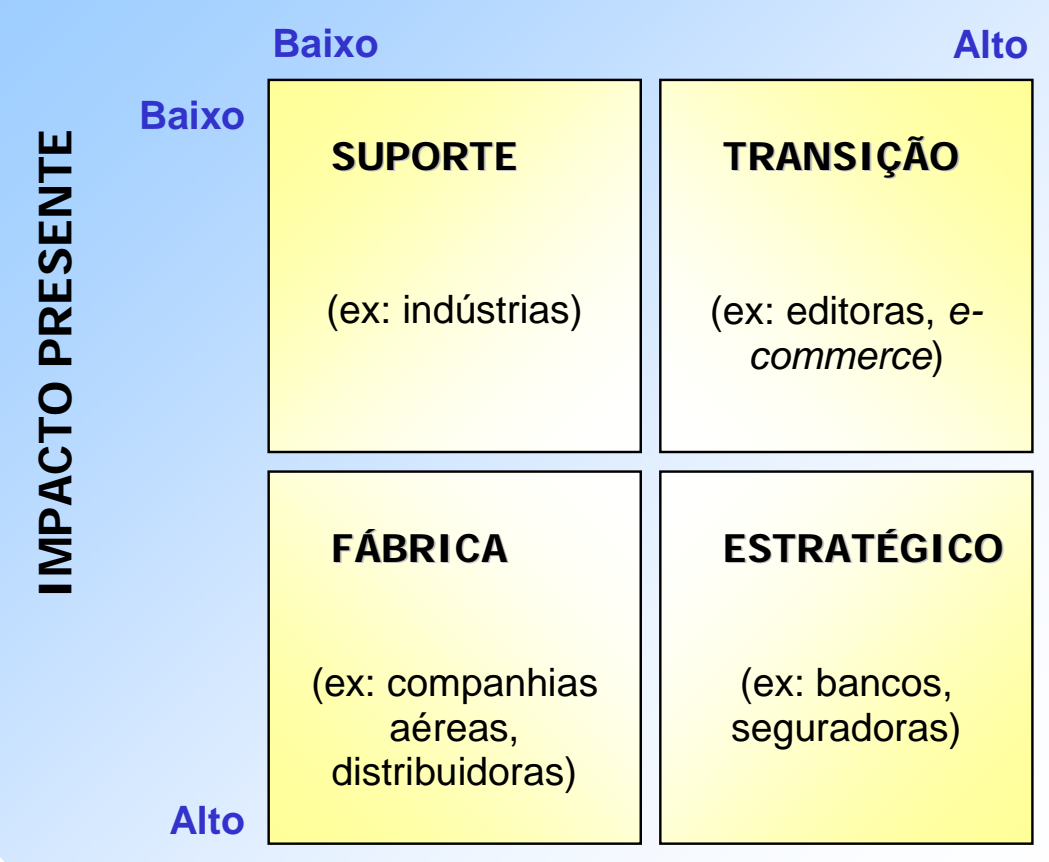

Figura 2.1 - Grid estratégico: impactos da aplicação da TI - Adaptado de McFARLAN (1984)

Segundo MENDES (1987), o bom gerenciamento da informática não tem o mesmo significado para todas as empresas, conforme se pode visualizar abaixo:

1. Quadrante Suporte: Para algumas empresas, a informática possui um papel útil e econômico, porém essencialmente de suporte, possuindo pequena influência na estratégia atual e futura da empresa e alguns ganhos simbólicos de eficiência (ex. indústria, contabilidade).

2. Quadrante Estratégico: Para outras empresas, a informática representa uma área de alta importância estratégica, posicionando-se no alto nível hierárquico. As aplicações atuais e futuramente em processo estão voltadas diretamente para o objetivo final da empresa (ex. banco, seguradora, transportadora). 
3. Quadrante Transição: Para certas empresas, a informática pode não ter impacto estratégico, hoje, no atendimento de seus objetivos, mas se planejam aplicações que terão grande significado no futuro. As aplicações estratégicas existem, mas ainda são planos (ex. editoras, e-commerce, supermercados médio porte).

4. Quadrante Fábrica: O oposto também ocorre, ou seja, existem empresas que aplicam, hoje, sua informática em atividades estratégicas, mas para o futuro, não prevêem aplicações de mesmo impacto. Limita-se à manutenção dos que têm e não visualizam desenvolvimento de outras aplicações de caráter estratégico (ex. companhias aéreas, transportadoras). Obs: O termo "Fábrica" foi utilizado por McFARLAN por analogia com um local da empresa onde se produz algo importante para a mesma, mas onde não se faz desenvolvimento de novos produtos.

Ainda segundo McFARLAN (1984), as mudanças técnicas têm sido tão repentinas, que o papel da função dos sistemas de informações de uma empresa tem que serem revistos esporadicamente, para assegurar que sua localização ainda esteja correta. Vale ressaltar que é muito importante reconhecer a correta localização da empresa dentro do grid estratégico, bem como de seus concorrentes, uma vez que a rápida mudança no desempenho da TI quanto à evolução das condições competitivas alteram-se repentinamente, podendo ocasionar uma estratégia errônea de difícil e oneroso retorno.

MENDES (1987) ressalta a importância das diferenças entre os quadrantes estratégicos, no qual é essencial para o sucesso da organização da informática em qualquer empresa, pois do contrário, muitas organizações podem apresentar problemas por falharem nesta área.

\subsection{Método fatores críticos de sucesso}

Cada vez mais, torna-se crítica a necessidade de respostas rápidas e confiáveis no ambiente profissional. Neste contexto, é necessário que os atuais 
sistemas de informação assegurem o fornecimento das reais informações por parte dos gerentes e altos executivos que, desde a década de 70 até os dias de hoje, ainda expressam preocupação/ dificuldade na obtenção destas informações/ relatórios.

ROCKART (1979), observando este cenário, propôs quatro abordagens principais para definir as informações necessárias a nível gerencial:

- Técnica do Subproduto: nesta abordagem, a organização do processo de informação (baseado em computadores) está centralizado no desenvolvimento de sistemas transacionais que, essencialmente realizam uma rotina de processamento de um trabalho/ relatório geralmente disponível para todos os executivos interessados da empresa, bem como, sumarizados e repassados para a alta gerência. Entretanto, esta abordagem possui o inconveniente de não atuar de forma integrada quando da análise das informações por parte dos executivos, havendo à necessidade de outros métodos auxiliares para uma visão geral gerencial.

- Abordagem Nula: contrariamente a Técnica do Subproduto, esta abordagem é caracterizada por uma comunicação informal, disponibilizada oralmente por estratégicos conselheiros confiáveis, no qual as informações necessárias para a tomada de decisão são dinâmicas e dependem essencialmente da atual situação no momento decisivo. Outro ponto também a ser destacado é, provavelmente existem informações que afetam na decisão por parte da alta gerência que não são apresentadas em relatórios padronizados, porém devem ser comunicadas informalmente, oralmente ou em conversas subjetivas. Vale lembrar que, as informações por meio de relatórios padronizados podem e devem ser disponibilizados regularmente para os altos executivos através de sistemas computadorizados. Outro ponto importante a ser destacado é que esta abordagem evita a possibilidade de desenvolver sistemas de informação inúteis à empresa.

- Sistema do Indicador Chave: esta abordagem basicamente consiste de três conceitos, no qual o primeiro deles é caracterizado pela seleção de indicadores essenciais da saúde do negócio onde as informações são 
coletadas a partir de cada um destes indicadores. Já o segundo conceito consiste em um relatório excepcional, ou seja, a habilidade de disponibilizar para a gerência, caso desejado, apenas aqueles indicadores onde o desempenho está significativamente diferente do resultado esperado. Desta forma, o executivo pode, portanto possuir uma visão geral da empresa e/ou atuar/focar apenas nas áreas divergentes do planejado. O terceiro conceito provê basicamente o glamour dos resultados, também tangível de benefícios, ou seja, disponibiliza as informações melhores, mais acessíveis e de melhor flexibilidade de maneira clara, objetiva e com efeitos visuais, utilizando-se de cores, gráficos e tecnologia para a obtenção dos resultados esperados. Esta abordagem se por um lado apresenta-se de maneira útil, por outro lado possui o grande inconveniente de destacar o aspecto financeiro, de interesse geral, mas deixando de tratar outros aspectos relevantes. Além disso, há o risco das empresas concentrarem-se na gestão dos indicadores como um fim, ao invés de concentrarem-se na gestão dos negócios que os indicadores permitem monitorar (LAURINDO, 2002).

- Processo de Estudo Total: esta quarta abordagem baseia-se no questionamento exaustivo aos executivos sobre suas reais necessidades de informação, sendo os resultados posteriormente comparados com os sistemas de informação existentes. Esta abordagem é um resultado de duas décadas de processamento de dados durante o qual, sistemas simples foram desenvolvidos para um uso em particular com relativa isolação entre eles e não focando as necessárias informações gerenciais. Os objetivos deste processo são desenvolver um entendimento total do negócio, das informações necessárias para o gerenciamento do negócio e dos sistemas de informação existente. A partir deste ponto, deve-se identificar as lacunas existentes entre os atuais sistemas de informação, objetivando no desenvolvimento e implementação um novo sistema que preencha as lacunas observadas e no atendimento das necessidades gerenciais. Este processo de entendimento total, se por um lado mostra-se benéfico, por outro lado despende muitos recursos em termos de mão de obra e tempo para ser realizado, sendo que, ao final, geralmente é difícil determinar o nível correto de agregação das 
informações necessárias que afetam a todos envolvidos, desde gerentes até altos executivos.

Diante das dificuldades no uso destas abordagens, ROCKART (1979) propôs um novo método utilizado para planejar e priorizar os sistemas de informação gerencial denominado "Fatores Críticos de Sucesso" (FCS). Basicamente este método consiste em obter pelos próprios gerentes suas reais necessidades de informação, no qual o sistema de informação sobre o desempenho de uma empresa deve ser baseado nas necessidades correntes da alta gerência. Ainda de acordo com o autor, o método FCS é, entretanto, para qualquer tipo de negócio, o número limitado de áreas nas quais o resultado se satisfatório, garante o desempenho competitivo bem-sucedido para a empresa, onde estas poucas áreas essenciais devem funcionar adequadamente para a prosperidade do negócio.

BOYNTON; ZMUD (1984) apontam que os FCS são atividades que devem obrigatoriamente apresentar um excelente desempenho para o sucesso da gerência e da empresa e, portanto, as áreas responsáveis por tais atividades, devem receber uma atenção especial e contínua pela gerência, assim permitindo elevados índices de desempenho e eficácia, devendo ser continuamente mensurados/ medidos e reavaliados, uma vez que as respectivas necessidades de informação podem mudar ao longo do tempo e também podendo diferenciar de um executivo individual para outro.

BULLEN, C. V.; ROCKART, J. F. (1981) apud BOYNTON; ZMUD (1984) aprofundarem-se na definição dos FCS e propuseram que este método deve ser usado como uma ferramenta de planejamento dos Sistemas de Informação Gerencial (SIG), onde se utilizando desta forma, gerentes de diversos níveis hierárquicos de uma empresa, não só podem como devem ser entrevistados. 


\subsubsection{O desenvolvimento e aplicação do método FCS}

O uso do conceito FCS como uma metodologia para direcionar e priorizar o desenvolvimento de sistemas de informação foi introduzida inicialmente por JOHN ROCKART como um mecanismo para definir as necessidades da alta gerência, onde entrevistas são realizadas entre um analista e um chefe executivo, identificando os reais FCS. ROCKART (1979) descreve o processo de aplicação do método FCS da seguinte maneira:

“As entrevistas voltadas ao FCS são usualmente realizadas em duas ou três sessões separadas. Na primeira, as metas do executivo são inicialmente registradas e os FCS referentes aos objetivos são discutidos. A inter relações dos FCS com as metas são então discutidas para esclarecimentos adicionais e para determinar quais dos FCS registrados devem ser fundidos, eliminados ou escritos de forma diferente. Na primeira entrevista são também delineados os critérios de medição para os FCS. A segunda sessão é usada para revisar os resultados da primeira, depois que o analista teve a chance de pensar sobre eles e de sugerir/ explorar melhor alguns fatores. Além disso, os critérios de medição e possíveis relatórios informativos são discutidos com profundidade. Às vezes, uma terceira sessão pode ser necessária para chegar a um acordo final quanto à seqüência envolvida em medir os FCS e informar as medições”.

Segundo LAURINDO (2002), os quatro principais passos para a aplicação do método FCS são basicamente:

- Análise do ramo de atuação da empresa ou da natureza de atuação da área;

- Identificação dos FCS, conforme processo citado por ROCKART acima descrito;

- Definição de medidas dos FCS, tanto quantitativas quanto qualitativas;

• Definição de sistemas de informação para controle dessas medidas. 
Os resultados obtidos devem ser sintetizados e disponibilizados à toda organização de modo que, os recursos e as atividades necessárias se tornem portanto, objetivos a serem almejados pela empresa, resultando em FCS coletivos.

Na visão de TORRES (1989), em vez de focar processos empresariais ou estruturas de dados, este método procura identificar as possíveis aplicações a partir de uma visão por resultados, como apresentada pela gerência. No entanto, ainda segundo este autor, apesar de sua orientação para resultados ser muito atraente, algumas considerações precisam ser feitas.

Segundo CORNELIUS H. SULLIVAN JR. (1985) apud TORRES (1989), “... embora extremamente útil, a abordagem por FCS nunca foi aclamada como uma metodologia completa de planejamento. Ela assume uma boa dose de conhecimento, por parte dos usuários, a respeito de sistemas de informações, e é mais útil na identificação de sistemas de suporte às decisões para os executivos da alta administração da companhia que na proposição de sistema de informação integrado, envolvendo a companhia como um todo”.

Ainda segundo SULLIVAN, “enquanto essa técnica preenche um nicho, as suas limitações para uma abordagem interdepartamental, no que se refere aos sistemas de informações a tornam não mais do que uma panacéia metodológica”. Em outras palavras, as principais críticas quanto ao método exclusivo por FCS referemse ao fato de que não é possível ter uma visão do conjunto.

\subsubsection{Comentários sobre o método FCS}

Embora o método FCS possua um conceito básico para o desenvolvimento de sistemas de informação, especialmente sistemas a níveis gerenciais, este possui um impacto importante nas práticas de planejamento gerencial e estratégico. Além da utilização em planejamento de sistemas de informação e gerenciamento de projetos de sistemas de informação, é também utilizado largamente em planejamento e 
implementações estratégicas, gerenciamento de modificação e como uma técnica de análise competitiva (POLLALIS; FRIEZE, 1993 apud LAURINDO, 2002).

Retomando ROCKART (1979), pode-se afirmar que o método dos FCS possui significativos benefícios, conforme a seguir:

- O processo ajuda o gerente a determinar os fatores nos quais a atenção de gerenciamento deve ser focalizada. Também ajuda a garantir que os fatores significativos receberão cuidado e análise minuciosa contínua a nível gerencial.

- O processo força o gerente a desenvolver boas medições para esses fatores e procura relatórios dessas medidas.

- A identificação dos FCS permite uma clara definição do real montante de informações que devem ser necessariamente coletadas pela organização e limita o custo de manter mais dados do que é realmente necessário.

- A identificação dos FCS evita a armadilha de construir relatórios e sistemas de informação em torno apenas dos dados que sejam "fáceis de coletar". Portanto, é melhor focar a atenção naqueles dados que podem por um lado não ser coletados, porém são significativos para o sucesso da empresa e em particular dos gerentes envolvidos.

- O processo reconhece que alguns fatores são temporários e que os FCS são específicos para cada gerente. Portanto, o sistema de informação deve ser constantemente ajustado através da criação de novos relatórios conforme necessário, para acomodar modificações na estratégia da organização, no ambiente ou na estrutura organizacional. Melhor que, alterar um sistema de informação é mantê-lo como indicador de adequação ou não do projeto, devendo ser visualizado como uma peça inevitável e produtiva no desenvolvimento de sistemas de informação.

- O conceito FCS por si mesmo é útil para mais do que o simples projeto de sistemas de informação. Basicamente permite melhorar significativamente diversas áreas e/ou funções de importância vital para a empresa. 
BOYNTON; ZMUD (1984) resumiram os Pontos Fortes e Fracos do método FCS através da tabela 2.1.

Tabela 2.1 - Pontos fortes e fracos do método FCS - Adaptado de BOYNTON;

ZMUD (1984)

\section{PONTOS FORTES E FRACOS DO FCS}

\section{PONTOS FORTES / POSITIVOS}

1. Fornece um suporte efetivo para o processo de planejamento;

2. Desenvolve idéias criativas no serviço de informação que pode impactar a posição competitiva da empresa;

3. São recebidos com grande entusiasmo pela gerência sênior, no qual identifica com intimidade o conceito FCS;

4. Serve como um nível elevado de análise estrutural e promove um processo de análise estruturado.

\section{PONTOS FRACOS / NEGATI VOS}

1. Caso o originador seja removido do processo, os gerentes seniores dentro da empresa, possui maior dificuldade em identificar os FCS organizacionais significativos;

2. Os gerentes que não estão envolvidos com o planejamento estratégico e tático podem apresentar dificuldades em lidar com a natureza conceitual dos FCS;

3. Certos gerentes possuem dificuldades em averiguar se apenas os FCS atendem suas necessidades de informação.

Nota-se que o método FCS não pode ser aplicado isoladamente, uma vez que não conduz a uma visão integrada dos processos, sendo necessária no planejamento de sistemas de informações, principalmente para os sistemas básicos relacionados às operações da companhia.

Segundo TORRES (1989), se por um lado o método FCS apresenta a vantagem de uma visão aberta, por parte da alta gerência, em termos de como vêem a 
administração estratégica da empresa, por outro lado pode levar a uma visão por problemas, deixando eventualmente de tratar de questões efetivamente estratégicas. Em outras palavras, o questionamento do posicionamento estratégico da empresa precisa ser conduzido por um processo sistemático para efetivamente tratar de questões realmente estratégicas. Caso contrário, corre o risco de se tornar apenas um instrumento reforçador dos rumos atuais da empresa, que podem obviamente, não ser os melhores.

Finalmente, analisando a bibliografia acima mencionada, pode-se dizer que uma parte das informações necessárias de um processo integrado não é continuamente desejada ano a ano: ou seja, algumas informações são necessárias apenas durante um período de vida de um projeto - "status do projeto”. Portanto, os FCS devem ser periodicamente revistos, descontinuando alguns relatórios e indicando outros. Outro ponto conclusivo é que a metodologia dos FCS deve ser apenas um dos componentes de um processo total, uma vez que é preciso de uma visão integrativa dos sistemas de informação de uma empresa.

\subsection{Análise de como a TI influencia a estratégia}

Com a grande velocidade da evolução dos computadores e a significativa redução no custo destes equipamentos e dos sistemas de informação, torna-se cada vez mais acessível o uso de aplicações de TI, não apenas como suporte às atividades administrativas, mas também, como sistemas que oferecem vantagens competitivas significativas.

Segundo McFARLAN (1984), esta nova tecnologia traz para a empresa a oportunidade de alterar a utilização de seus ativos e repensar sua estratégia. Porém vale salientar que as oportunidades geradas variam muito de uma empresa para outra, assim como, a intensidade e as regras da competição variam de um setor para outro.

Para avaliar o impacto definitivo da TI, McFARLAN (1984) relata que as empresas têm que abordar cinco perguntas estratégicas que, conforme a resposta a 
uma ou mais destas perguntas for “positiva”, a TI representa um recurso estratégico que exige atenção do mais alto nível. Cada uma destas perguntas diz respeito as cinco forças competitivas que determinam a concorrência, na visão de PORTER (1979).

1. A TI pode erguer barreiras para a entrada de outros concorrentes no mercado?

Uma barreira de entrada bem sucedida oferece, não apenas um novo serviço para agradar os clientes, mas também oferece características que mantêm seus clientes cativos. Portanto, quanto mais difícil de copiar for o serviço prestado, mais altas são as barreiras para a competição e mais alto é o retorno advindo do valor agregado gerado, ocasionando ganhos vantajosos no custo do produto, no qual permite pressionar seus concorrentes diretamente.

Por outro lado, não se pode esquecer que são grandes os investimentos de capital exigidos por esses projetos, tendo que conviver com a incerteza de seus benefícios finais. Além disso, tais investimentos nesses sistemas eletrônicos podem criar uma séria rigidez nos custos, assim como barreiras para que a empresa possa se retrair ou se retirar do setor, quando bem o desejar.

2. A TI pode impedir a troca de fornecedor?

O desenvolvimento de sistemas eletrônicos que encorajam os clientes a contarem, cada vez mais, com o suporte do fornecedor, incorporando-o às suas operações, garante significativamente a dependência operacional e uma inércia humana normal, no qual se torna indesejável a mudança de fornecedor. Diante deste cenário, se o cliente optar em mudar de fornecedor, terá que despender muito tempo e capital na reformulação de um novo processo. 


\section{Pode a TI alterar as bases da competição?}

PORTER (1979) discute três tipos de estratégias competitivas tendo, cada uma delas, diferentes regras básicas. Uma delas é baseada em custo, ou seja, quando a empresa pode produzir com um custo muito inferior do que seus concorrentes. As empresas que vendem “commodities” e produtos de alta tecnologia são marcantes exemplos da utilização de tais estratégias. Um segundo tipo de estratégia é baseado na diferenciação do produto, isto é, quando uma empresa oferece uma combinação diferente de características no produto, tais como serviço e qualidade. Já o terceiro tipo é a especialização em apenas um nicho de mercado, distinguindo-se por características raras em termos de custo ou no produto, podendo ser chamadas de estratégias de foco.

Retomando McFARLAN (1984), vêem-se em suas afirmações que em alguns setores dominados pela competição em custo, a TI permitiu o desenvolvimento de características de produto que se tornaram tão diferentes que fazem com que as bases da competição se alterem radicalmente. Simplesmente a empresa utiliza-se da TI para agregar valor ao produto, mudando conseqüentemente às bases da competição, de custo para diferenciação de produto ou vice-versa.

Basicamente os primeiros estágios são de difícil distinção entre uma inovação intrigante e uma inovação estrutural importante, pois se os gerentes não souberem interpretar qualquer uma dessas questões, as conseqüências podem ser desastrosas.

4. A TI pode alterar o equilíbrio de poder nas relações com os fornecedores?

CASH Jr; KONSYNSKI (1985) afirmam que os usos mais avançados e potencialmente poderosos da tecnologia de sistemas de informação envolvem redes que transcendem as fronteiras da própria empresa, tendo alguns desses sistemas interorganizacionais (IOS - Interorganizacional Systems) importantes implicações sociais e políticas. Esses sistemas de informação automatizados, compartilhados por duas ou mais empresas, 
podem contribuir, significativamente, para melhorar a produtividade, a flexibilidade e a competitividade de muitas empresas. Portanto, pode-se constatar que alguns exemplos reais ilustram que alguns IOSs podem mudar o equilíbrio de poder nas relações comprador-fornecedor, prover barreiras à entrada e saída das empresas nos setores industriais e, na maioria das vezes, mudar a posição competitiva entre concorrentes intra-setoriais. Como exemplo desta perspectiva, pode-se citar o sistema de entrega Just-in-time, podendo reduzir drasticamente os níveis de estoque nas indústrias, principalmente automobilísticas, permitindo, portanto, grandes economias de custo.

Tais sistemas interorganizacionais, podem redistribuir o poder entre compradores e fornecedores, ou seja, em alguns casos o fabricante pode aumentar a dependência de um fornecedor individual, tornando mais difícil de ser substituído e deixando a empresa vulnerável a maiores aumentos de preço, mas por outro lado, existem situações em que o fabricante alcança uma posição bem mais forte para ditar os termos de seu relacionamento com os fornecedores. McFARLAN (1984)

\section{A TI pode gerar novos produtos?}

Como descrito anteriormente, a TI pode levar a produtos de melhor qualidade que podem ser entregues mais rapidamente e cuja produção custe menos. Similarmente a um custo ligeiramente maior, os produtos existentes podem ser personalizados para atender as necessidades específicas do cliente. Diante deste cenário, pode-se verificar em algumas organizações a combinação de uma ou mais dessas vantagens, nas quais estas podem se associar a um serviço de suporte eletrônico, em um de seus produtos, a fim de aumentar seu valor aos olhos do consumidor final. Como exemplo, pode-se citar um sistema online de atendimento direto ao consumidor, provendo maior suporte e agregando valor ao produto, mediante a um pequeno custo adicional no sistema disponibilizado. 


\subsection{Análise de como a informação proporciona vantagem competitiva}

Cada vez mais se pode observar a crescente utilização da TI e seus respectivos efeitos, com o intuito fundamental de se obter uma vantagem competitiva. É notável que a revolução da informação está mudando processos e comportamentos, no qual todas as empresas que quiserem sobreviver mediante ao atual mercado competitivo, terá que se atualizar, despendendo tempo e capital de investimentos, a fim de usufruir seus benefícios.

PORTER; MILLAR (1985) relatam que cada vez mais os executivos têm consciência crescente de que a TI não pertence mais exclusivamente ao território do processamento eletrônico de dados ou aos departamentos de sistemas de informação. Para obter vantagem competitiva, tais executivos reconhecem a necessidade de se tornarem diretamente envolvidos no gerenciamento das novas tecnologias.

Segundos os autores “a revolução da informação está afetando a competição de três formas vitais:

Ela muda a estrutura do setor e, ao fazê-lo, altera as regras da competição.

Ela cria vantagens competitivas, proporcionando ás empresas novas formas de superar seus rivais.

Ela dá origem a negócios completamente novos, começando, freqüentemente, dentro das operações já existentes na empresa.”

DAVENPORT; HAMMER; METSISTO (1989) entendem que no passado os gerentes simplesmente delegavam decisões tecnológicas aos especialistas dos computadores da empresa e cuidavam de outros assuntos, porém nos dias de hoje, tais gerentes não podem evitar facilmente o processo de tomada de decisões sobre TI, na qual afeta os negócios como um todo, desde a estrutura organizacional até as estratégias de produto no mercado. Portanto, delegar decisões importantes não assegura que os investimentos em TI melhorarão a estratégia dos negócios da empresa. 


\subsection{A cadeia de valor}

Retomando PORTER; MILLAR (1985), vêm-se em suas afirmações que a TI está mudando a maneira como as empresas operam, afetando todo o processo através do qual elas criam os seus produtos. Além disso, está reformulando o próprio produto, ou seja, todo o pacote de bens físicos, serviços e informação que as empresas provêem para gerar valor à seus clientes. Em meio a este cenário, um conceito importante que faz sobressair o papel da TI na competição é a chamada "Cadeia de Valor", no qual divide as atividades da empresa em atividades tecnológica e economicamente distintas. Pode-se dizer que o valor que uma empresa gera é medido pela quantidade de clientes que se dispõe a pagar pelo produto ou serviço. Já um negócio é lucrativo, se o valor que ele gera excede os custos de execução das atividades de valor, sendo que para obter-se vantagem competitiva sobre seus concorrentes, uma empresa tem que ou executar essas atividades a um preço menor, ou executá-las de uma forma que conduza a uma diferenciação e a um preço especial, ou seja, que agregue mais valor.

PORTER (1985) explica claramente uma relação entre a cadeia de valor e a vantagem competitiva ao conceituar que: “Toda empresa é uma reunião de atividades que são executadas para projetar, produzir, comercializar, entregar e sustentar seu produto. Todas essas atividades podem ser representadas, fazendo-se uso de uma cadeia de valores (...) As diferenças entre cadeias de valores concorrentes são uma forma básica de vantagem competitiva”. O autor acrescenta, afirmando que "a vantagem competitiva surge fundamentalmente do valor que uma empresa consegue criar para seus compradores e que ultrapassa o custo de fabricação pela empresa”.

A cadeia de valor de uma empresa é uma série de atividades independentes que são conectadas por "ligações” que concretiza e entrega um produto ou serviço a um consumidor. Tais ligações existem quando a maneira como cada atividade é executada, afetando o custo ou a eficiência de outras atividades. Vale reforçar que as ligações requerem que as atividades sejam coordenadas, acarretando em uma verdadeira fonte poderosa de vantagens competitivas (PORTER; MILLAR, 1985). 
A figura 2.2 exibe uma cadeia de valor típica, desenvolvida a partir da análise de MICHAEL PORTER, a qual define brevemente o significado das atividades de uma empresa, que se dividem em nove categorias genéricas. As atividades primárias são aquelas envolvidas na criação física do produto, seu marketing e entrega aos compradores e seu suporte e assistência pós-venda. As atividades de suporte provêem os insumos e a infra-estrutura que permitem que as atividades primárias aconteçam, sendo que cada atividade emprega insumos, recursos humanos e uma combinação de tecnologias pelas quais se paga um preço. Dentro de cada categoria genérica, uma empresa executará um número definido de atividades, dependendo da natureza de seus negócios. Os serviços, por exemplo, freqüentemente incluem atividades como instalações, reparo, adaptações, upgrades e gerenciamento de estoque de peças.

\begin{tabular}{|c|c|c|c|c|c|c|c|}
\hline \multirow[t]{6}{*}{ Atividades-meio } & $\begin{array}{l}\text { Infra-estrutura } \\
\text { empresarial }\end{array}$ & & & & & & \\
\hline & $\begin{array}{l}\text { Gerenciamento de } \\
\text { recursos humanos }\end{array}$ & & 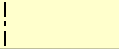 & & & & \\
\hline & $\begin{array}{l}\text { Desenvolvimento de } \\
\text { tecnologias }\end{array}$ & & 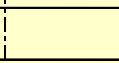 & & & & \\
\hline & $\begin{array}{l}\begin{array}{l}\text { Aquisição de } \\
\text { insumos }\end{array} \\
\end{array}$ & & 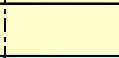 & & & & \\
\hline & & \begin{tabular}{|l|} 
Logística \\
Interna
\end{tabular} & Operações & $\begin{array}{l}\text { Logística } \\
\text { Externa }\end{array}$ & \begin{tabular}{|l} 
Marketing e \\
Vendas
\end{tabular} & $\begin{array}{l}\text { Prestação de } \\
\text { Serviços }\end{array}$ & \multirow[b]{2}{*}{ Margem } \\
\hline & & \multicolumn{5}{|c|}{ Atividades-fim } & \\
\hline
\end{tabular}

Figura 2.2 - A cadeia de valor - Adaptado de PORTER; MILLAR (1985) e PORTER (1985)

Ainda se encontra em PORTER; MILLAR (1985) que a cadeia de valor de uma empresa em um determinado setor está embutida em uma corrente mais ampla de atividades, a que se chama de "sistema de valor", conforme se pode visualizar na figura 2.3. O sistema de valor inclui as cadeias de valor de fornecedores, que provêem insumos, tais como matéria-prima, componentes e serviços adquiridos, para a cadeia de valor da empresa. Os produtos da empresa, freqüentemente passam pelas cadeias de valor de seus canais, a caminho do consumidor final e, finalmente, o produto se torna um insumo acabado, comprado pelas e para as cadeias de valor de seu consumidor, que o usam para executar uma ou mais atividades. 

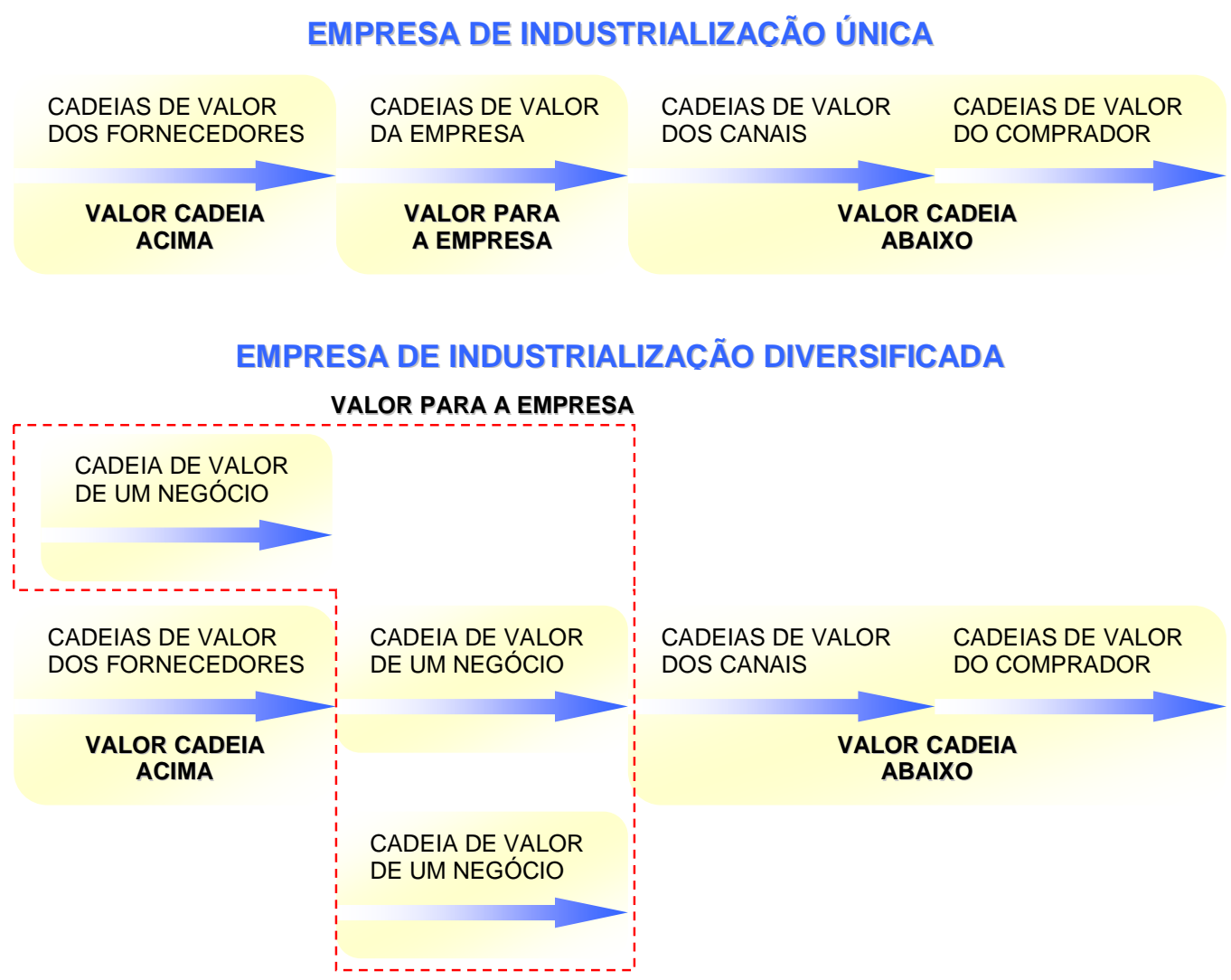

Figura 2.3 - O sistema de valor - Adaptado de PORTER; MILLAR (1985) e PORTER (1985)

CLEMOUNS; McFARLAN (1988) acreditam que uma análise sistemática da cadeia de valor de uma empresa é uma forma eficaz para buscar aplicações eficazes e lucrativas da TI. Essa análise requer uma visão administrativa apurada, consciência da estrutura do setor e familiaridade com as regras da concorrência. As empresas precisam compreender suas cadeias de valor, bem como aquelas de seus principais clientes e fornecedores para descobrir as áreas potenciais para novos serviços. Da mesma forma, a compreensão das cadeias de valor dos concorrentes fornece uma visão sobre a provável fonte de ataque da concorrência. Finalmente, faz-se necessário ponderar com cuidado para identificar os potenciais iniciantes no mercado, no qual costumam ser novos concorrentes cuja cadeia de valor se expande para uma área particularmente atraente. 


\subsubsection{Transformando a cadeia de valor}

A TI está permeando a cadeia de valor, transformando a maneira como as atividades de valor são executadas e a natureza das interligações entre elas, afetando a o escopo competitivo, bem como reformulando a maneira como os produtos atendem às necessidades do comprador. Estes efeitos básicos explicam por que a TI adquiriu um significado estratégico, diferenciando de muitas outras tecnologias utilizadas nos negócios (PORTER; MILLAR, 1985).

Com essa transformação tecnológica, as empresas estão ampliando seus limites daquilo que elas podem fazer em tempo menor do que o requerido para seus gerentes explorarem as oportunidades. Ainda se encontra em PORTER; MILLAR (1985), que a revolução da informação afeta todas as noves categorias de atividades de valor, desde a possibilidade de usar um projeto auxiliado por computador no desenvolvimento tecnológico, muito presente em indústrias automobilísticas, até a incorporação da automação nos depósitos, conforme se pode visualizar na figura 2.4.

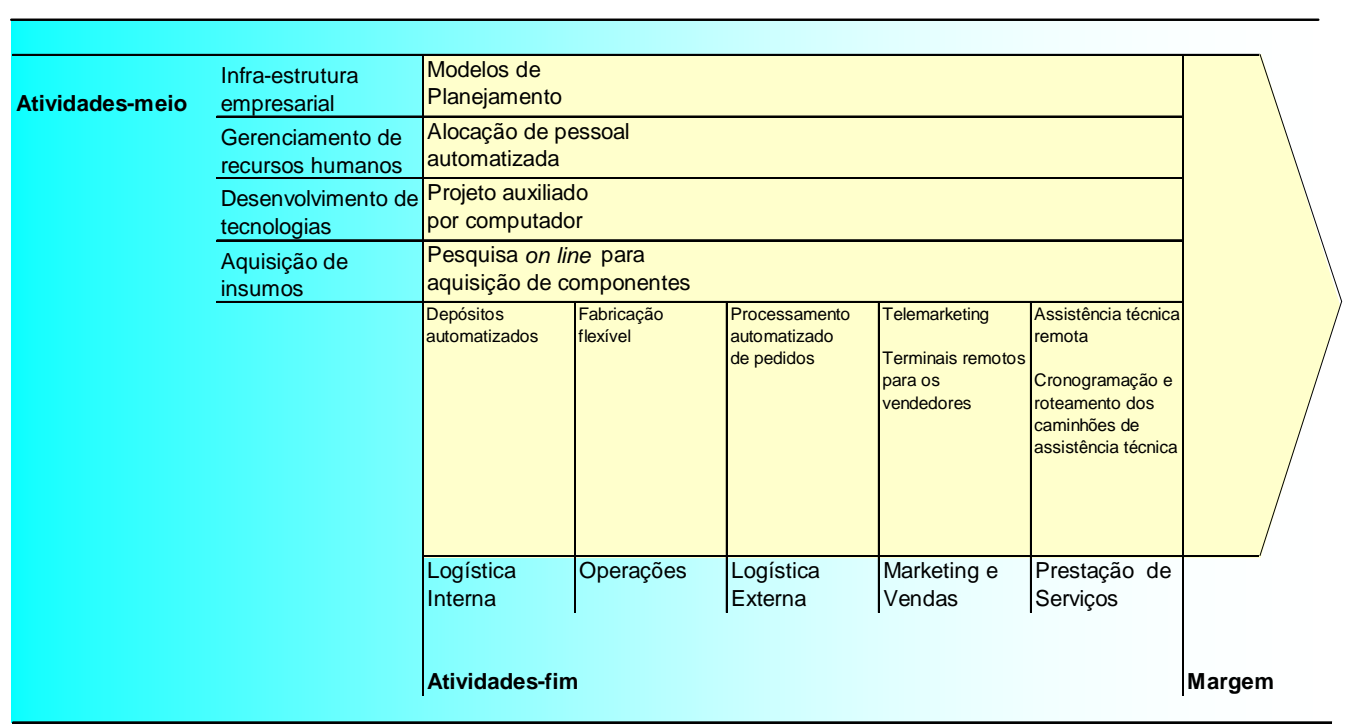

Figura 2.4 - A evolução da cadeia de valor com a TI - Adaptado de PORTER;

MILLAR (1985)

Percebe-se que a TI está gerando mais dados à medida que uma empresa executa as suas atividades, ou seja, está permitindo que ela colete ou capture 
informações que antes não eram possíveis. Também se pode dizer que a TI está transformando os componentes de processamento físico das atividades, isto é, máquinas operatrizes controladas por computador são mais rápidas, mais precisas e mais flexíveis na fabricação de um produto, do que as máquinas antigas operadas manualmente. PORTER; MILLAR (1985)

Ainda se encontra em PORTER; MILLAR (1985) que "a tecnologia da informação afeta não somente a maneira como as atividades individuais são executadas através de novos fluxos de informação, mas também eleva em muito a capacidade da empresa de explorar interligações entre as atividades, tanto internas, quanto externas à empresa. A tecnologia está criando novas interligações entre atividades e as empresas, agora, podem coordenar suas ações mais estreitamente com aquelas de seus clientes e fornecedores”.

Em contra partida, a mudança tecnológica não é importante por si só, mas é importante se afetar a vantagem competitiva e a estrutura da empresa. Toda mudança tecnológica não é estrategicamente benéfica, pois pode piorar a posição competitiva de uma empresa e sua atratividade. Portanto, somente a alta tecnologia não garante rentabilidade, devendo a empresa possuir uma estrutura favorável capaz de competir no atual mercado. Porém, vale ressaltar que a tecnologia, entretanto, penetra na cadeia de valor de uma empresa e se estende até o ponto que essas tecnologias associam-se diretamente com o produto (PORTER, 1985).

CATELLI (2001) ressalta a ausência de ferramentas capazes de avaliar a criação do valor econômico das atividades da cadeia de valor, ou seja, muitos sistemas somente se interessam em realizar medidas qualitativas de algumas características, como o desempenho, a satisfação de cliente, os padrões de ponto de referência de competidores e logística, bem como propor sistemas focalizados em medida de custo. 


\subsection{Matriz de intensidade de informação}

O impacto da TI é tão persuasivo que faz com que os executivos se confrontem com um grande problema: o excesso de informação, no qual vem criando novos usos da TI, para armazenar e analisar a avalanche de informações disponíveis aos executivos.

Diante deste cenário, a “Matriz de Intensidade de Informação” de PORTER e MILLAR é mais um modelo que analisa o impacto estratégico da aplicação da TI em uma empresa, retratando a intensidade das informações na cadeia de valor.

A figura 2.5 ilustra a Matriz de Intensidade de Informação, retratando a intensidade das informações na cadeia do valor para o conteúdo de informações no

produto entre diversos ramos de negócios. Portanto, pode-se perceber que a importância da tecnologia difere de um setor para outro, embora a tendência para uma maior intensidade de informações, tanto nas empresas, quanto nos produtos seja evidente.

No artigo original de PORTER e MILLAR, não há indicação de exemplo para o quadrante "alto conteúdo de informações no produto" e "baixa intensidade de informações na cadeia de valor (processo)”, posição que é corroborada por DOYLE (1991). Contudo, para WARD (1988) apud LAURINDO (2002), este seria o caso de empresas de educação e de advocacia. Segundo DUHAN et. al. (2001) apud LAURINDO (2002), empresas de consultoria também estariam neste mesmo enquadramento, onde a análise da cadeia de valor fica prejudicada no caso de empresas baseadas em conhecimento (como consultorias), nas quais é difícil identificar o valor que é agregado em cada atividade. Nestas situações, os autores defendem que a abordagem das competências essenciais de PRAHALAD; HAMEL (1990) apud LAURINDO (2002) seria mais adequada para planejar o uso estratégico dos sistemas de informação. Portanto, não é consenso que este quadrante deva estar preenchido, onde particularmente é difícil existir a situação onde se tem muita 
informação do produto sem muita informação do processo, gerando uma polêmica entre as literaturas.

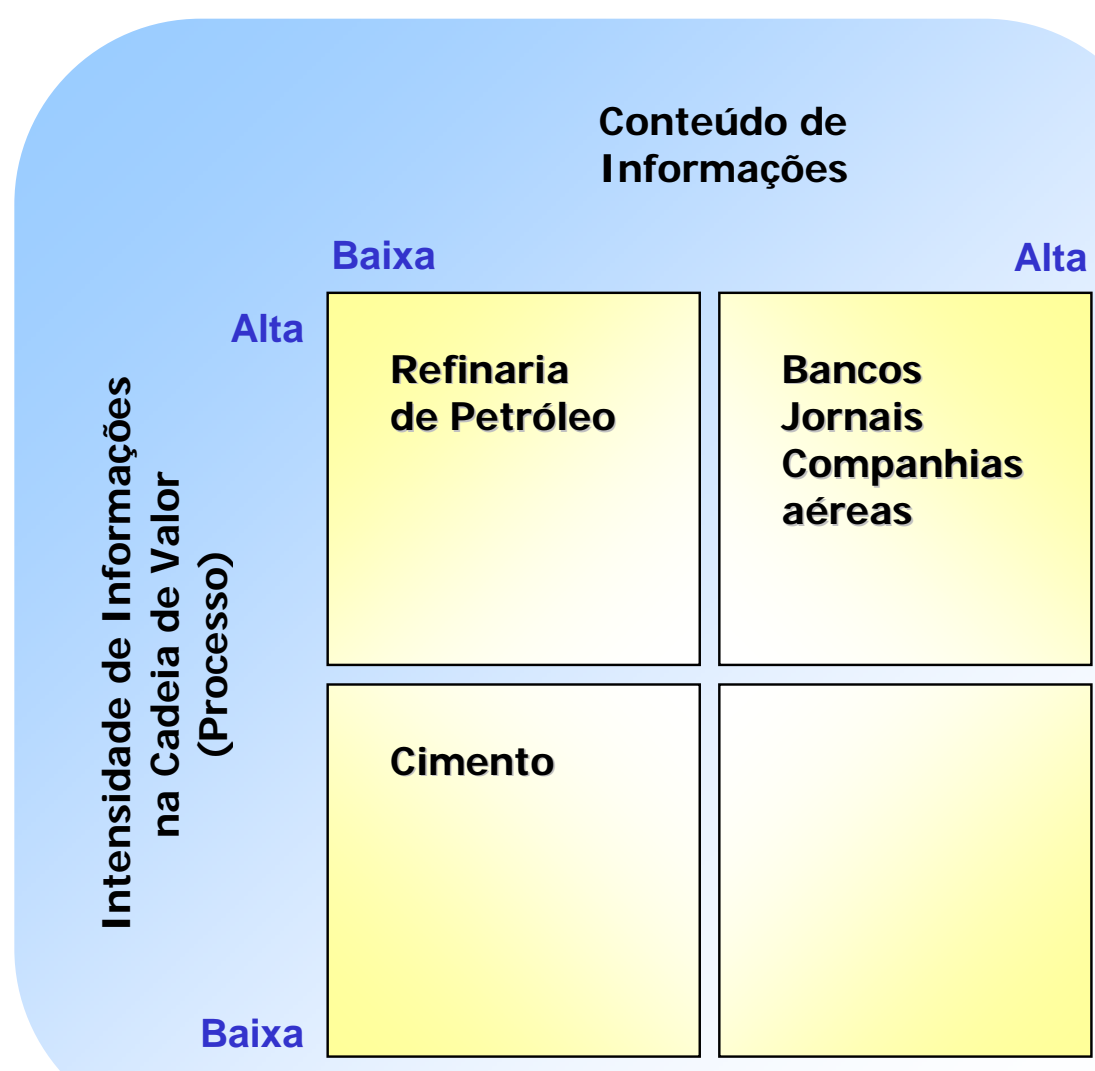

Figura 2.5 - Matriz de intensidade de informações - Adaptado de PORTER;

MILLAR (1985)

A TI está não apenas transformando produtos e processos, mas também a natureza da competição em si. Apesar do crescente uso da TI, as indústrias sempre diferirão em suas posições, conforme figura 2.5, e no seu ritmo de mudança. Diante disso, em uma indústria tradicional, a TI usualmente tem um papel de suporte à operação, pois dificilmente pararia caso seus sistemas de informação não estivessem operando, enquanto que um banco, no qual possui a TI como estratégia na operação do negócio, não conseguiria operar sem seus sistemas de informação computadorizados. 


\subsection{Modelo do alinhamento estratégico}

Cada vez mais se pode dizer que a TI tem evoluído de uma orientação tradicional de suporte administrativo, para uma função mais estratégica dentro da organização. Neste contexto, foi desenvolvido por HENDERSON e VENKATRAMAN (1993) um modelo para conceituar e direcionar as áreas emergenciais de gerenciamento estratégico da TI. Este modelo denominado de "Modelo do Alinhamento Estratégico" é definido em termos de quatro domínios fundamentais de escolha estratégica: Estratégia do Negócio, Estratégia da TI, Infraestrutura Organizacional e Processos e Infraestrutura da TI e Processos - cada um com características fundamentais para o planejamento da TI na organização.

O Modelo do Alinhamento Estratégico identifica as necessidades para especificar dois tipos de integração entre os domínios de Negócio e da TI. O primeiro denominado de "Ajuste Estratégico”, é a ligação entre a Estratégia e a Infraestrutura. Já o segundo tipo de integração é denominado de "Integração Funcional”, no qual estabelece a ligação entre as funções do Negócio e da TI nos âmbitos estratégicos e de infraestrutura. A TI deve ser articulada em termos de um domínio “externo” e de um domínio “interno” da empresa. O domínio externo é a arena empresarial, na qual a empresa compete e está preocupada com decisões mercadológicas, oferecendo atributos estratégicos distintivos que diferenciam a empresa de seus competidores, como também a gama de decisões de make or buy, formação de alianças estratégicas e inclusive sociedades. Em contraste, o domínio interno diz respeito à estrutura organizacional administrativa, as razões específicas para projetar/ reprojetar processos críticos, bem como para a aquisição e desenvolvimento de habilidades humanas necessárias para alcançar a competência organizacional requerida.

HENDERSON e VENKATRAMAN (1993) ilustram o Modelo do Alinhamento Estratégico, conforme figura 2.6, mostrando a gama de escolhas que podem ser endereçadas durante o processo gerencial. 


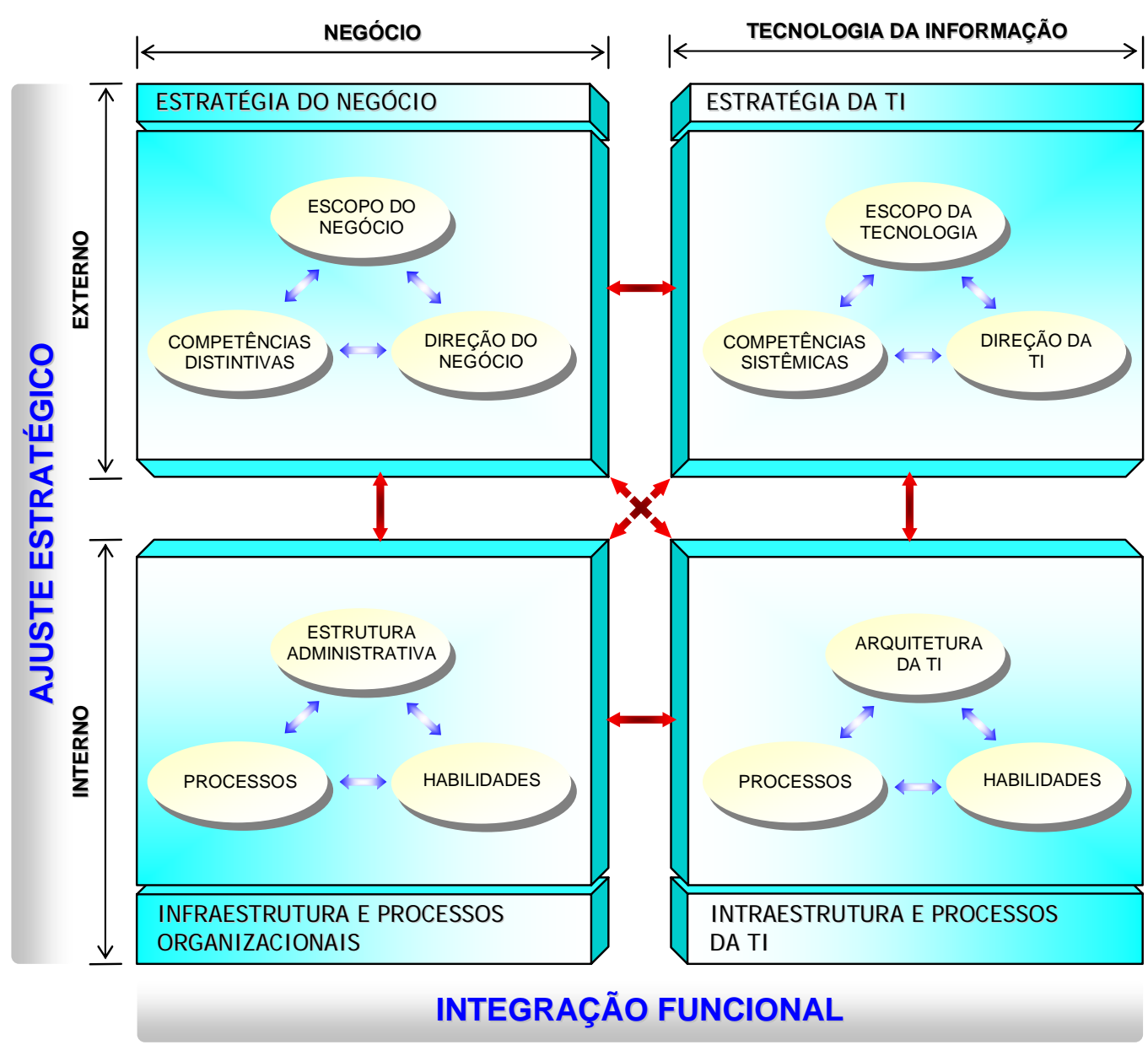

Figura 2.6 - Modelo do alinhamento estratégico - Adaptado de HENDERSON e VENKATRAMAN (1993)

\subsubsection{Descrição da terminologia do alinhamento estratégico}

Dois conceitos são importantes neste modelo:

\section{\ Ajuste Estratégico.}

O Ajuste Estratégico é a relação vertical do vigamento de alinhamento estratégico ilustrado na figura 2.6. O Ajuste Estratégico enfatiza a necessidade de fazer escolhas que posicionem o empreendimento em uma faixa externa e como melhorar a estrutura dos arranjos internos para executar esta estratégia de 
posicionamento no mercado. São chamadas as escolhas que posicionam o empreendimento em um mercado estratégico de negócio e essa escolha que determina a estrutura interna do empreendimento de infraestrutura e processos organizacionais. O desempenho do empreendimento está definido por, até que ponto as escolhas que contêm essas duas estratégias são consistentes e assim, mudando as estratégias do negócio, os processos organizacionais têm que acompanhar o mesmo passo. Semelhantemente, as escolhas verticais entre estratégia de TI e sua infraestrutura e processos devem ser consistentes. Portanto, utilizando-se a informática para aumentar estas escolhas verticais, provê-se a oportunidade para uma vantagem estratégica.

\section{- Integração Funcional.}

A relação horizontal da integração funcional, mostrada na figura 2.6, estende a noção do ajuste estratégico por domínios funcionais. Assim como as estratégias do negócio mudam, as estratégias de TI e seus processos também têm que manter o mesmo passo, sendo que se tem nestas situações as diferentes relações funcionais bem definidas. Infelizmente, a visão tradicional da estratégia de sistemas de informação é freqüentemente definida de maneira simplista, interessando somente as aplicações, os dados e as arquiteturas de hardware, no qual esta perspectiva interna não endereça a necessidade por administrar e entender como estas escolhas arquitetônicas posiciona a empresa dentro um mercado altamente dinâmico e evolutivo. Portanto, o posicionamento efetivo da empresa no mercado tecnológico é de vital necessidade, sendo que a integração funcional dá para TI a oportunidade para prover vantagem competitiva no atual mercado.

Segundo esse modelo, para planejar a TI, devem ser considerados quatro importantes fatores: 


\section{口 Estratégia do Negócio.}

$\checkmark$ Escopo do Negócio: Decisões que determinam onde o empreendimento competirá. Freqüentemente visto como segmentação de mercado, estas escolhas definem os tipos de produtos, nichos, clientes e geografia, que determinam o alcance ou a gama do empreendimento. Incluem as forças competitivas (os compradores, fornecedores, substitutos, concorrentes potenciais) como descrito por PORTER (1979).

$\checkmark$ Competências Distintivas: Áreas que determinam como o empreendimento competirá no fornecimento de seus produtos e serviços. Por que um cliente escolheria comprar ou usar os produtos / serviços de uma empresa em particular? Estas decisões determinam esses atributos da estratégia, que criam uma capacidade no empreendimento para diferenciar seus produtos e serviços de seus concorrentes. Pode-se citar como exemplos o foco em qualidade, o planejamento de uma estratégia direcionada, bem como o desenvolvimento de um canal de marketing aperfeiçoado.

$\checkmark$ Direção do Negócio: Escolhas que focalizam no assunto de propriedade, ou seja, se o empreendimento entrará em um mercado particular como uma única entidade ou por alianças, sociedades, ou outra fonte externa. Nos dias de hoje, a escolha da direção reflete um aspecto significante na estratégia, no qual um negócio pode tentar armazenar vantagens tradicionais de balança, por meio de alianças em lugar de propriedade.

\section{- Infraestrutura e Processos Organizacionais.}

$\checkmark$ Estrutura Administrativa: Representa as funções, responsabilidades, e estrutura hierárquica do empreendimento. Estabelece se o empreendimento será organizado por departamentos funcionais, quantos níveis gerenciais será requerido e até que ponto as decisões serão descentralizadas. Estas escolhas estabelecem a estrutura dentro da qual a administração e os processos de trabalho operarão. 
$\checkmark$ Processos: A maneira na qual as funções empresariais fundamentais operarão ou fluirão. Essencialmente, um assunto relacionado à cadeia de valor, determina-se até que ponto o trabalho deve ser reestruturado, talvez integrado, a fim de melhorar a eficiência e a eficácia. Freqüentemente a melhoria de processos ocasiona em mudanças na TI. Métodos de transformação empresariais concentram em acrescentar valor a escolhas estratégicas que focalizam em infraestrutura organizacional e processo (especialmente relativo a processo).

$\checkmark$ Habilidades: Escolhas relativas às pessoas que levarão adiante a estratégia. Quais experiências, competências, compromissos, valores e normas são exigidos dos profissionais, a fim de conhecer a estratégia? A estratégia do negócio solicitará habilidades novas? Mudanças adicionais estão em conflito com valores tradicionais e normas do empreendimento? A estratégia de infraestrutura organizacional tem que definir as considerações de recurso humano claramente, a fim de finalizar o trabalho. Oportunidades para outras fontes também são consideradas neste item.

\section{- Estratégia da TI.}

$\checkmark$ Escopo da Tecnologia: Tipos específicos de tecnologia que são críticos a organização (exemplo: imagens eletrônicas, robótica, multimídias, etc.). Estas decisões posicionam a tecnologia necessária para se ter êxito.

$\checkmark$ Competências Sistêmicas: Atributos da estratégia da TI que podem contribuir positivamente para a criação de novas estratégias de negócio, ou melhor, pode suportar a estratégia de negócio existente. Este item é análogo ao conceito das competências distintivas do negócio, na qual lida com atributos estratégicos (preço, qualidade, canais de distribuição superior, valor-serviço adicionado) que contribuem para uma distinção positiva mediante aos concorrentes.

$\checkmark$ Direção da TI: Seleção e uso de mecanismos (exemplos: joint ventures com vendedores, alianças estratégicas, pesquisa em comum e 
desenvolvimento para capacidade de nova TI) para a obtenção de competências requeridas da TI. Este item é análogo a direção do negócio, no qual envolve escolhas de make or buy na estratégia do negócio.

\section{- Infraestrutura e Processos Organizacionais da TI.}

Todos os itens deste domínio são análogos aos itens do domínio Infraestrutura Organizacional.

$\checkmark$ Arquitetura da TI: Escolhas, prioridades e políticas que habilitam a síntese de aplicações, dados, software e hardware por uma plataforma aderente.

$\checkmark$ Processos: Planejamento das funções principais de trabalho da TI e suas práticas - como desenvolvimento de aplicação, controles de gerenciamento de sistemas ou operações.

$\checkmark$ Habilidades: Experiência, competências, compromissos, valores e normas dos indivíduos que trabalham para entregar os produtos e serviços ligados a TI.

Outra premissa do Modelo do Alinhamento Estratégico é que uma administração eficaz da TI requer um balanceamento entre as decisões em todos os quatro fatores descritos acima. Este balanceamento reflete uma interação entre três domínios essenciais, formando uma espécie de um triângulo. Pode-se notar que, criando perspectivas que refletem o alinhamento cruz-dimensional (ilustrado a seguir nas figuras 2.7 e 2.8), no mínimo, tem-se sempre uma relação envolvendo o ajuste estratégico e a integração funcional. Cada triângulo consiste em três componentes:

• Domínio Âncora: Área que provê (dirige) a mudança ao domínio;

๑ Domínio Pivô: Área com o problema;

a Domínio impactado: Área que é afetada pela mudança, devido ao domínio pivô. 


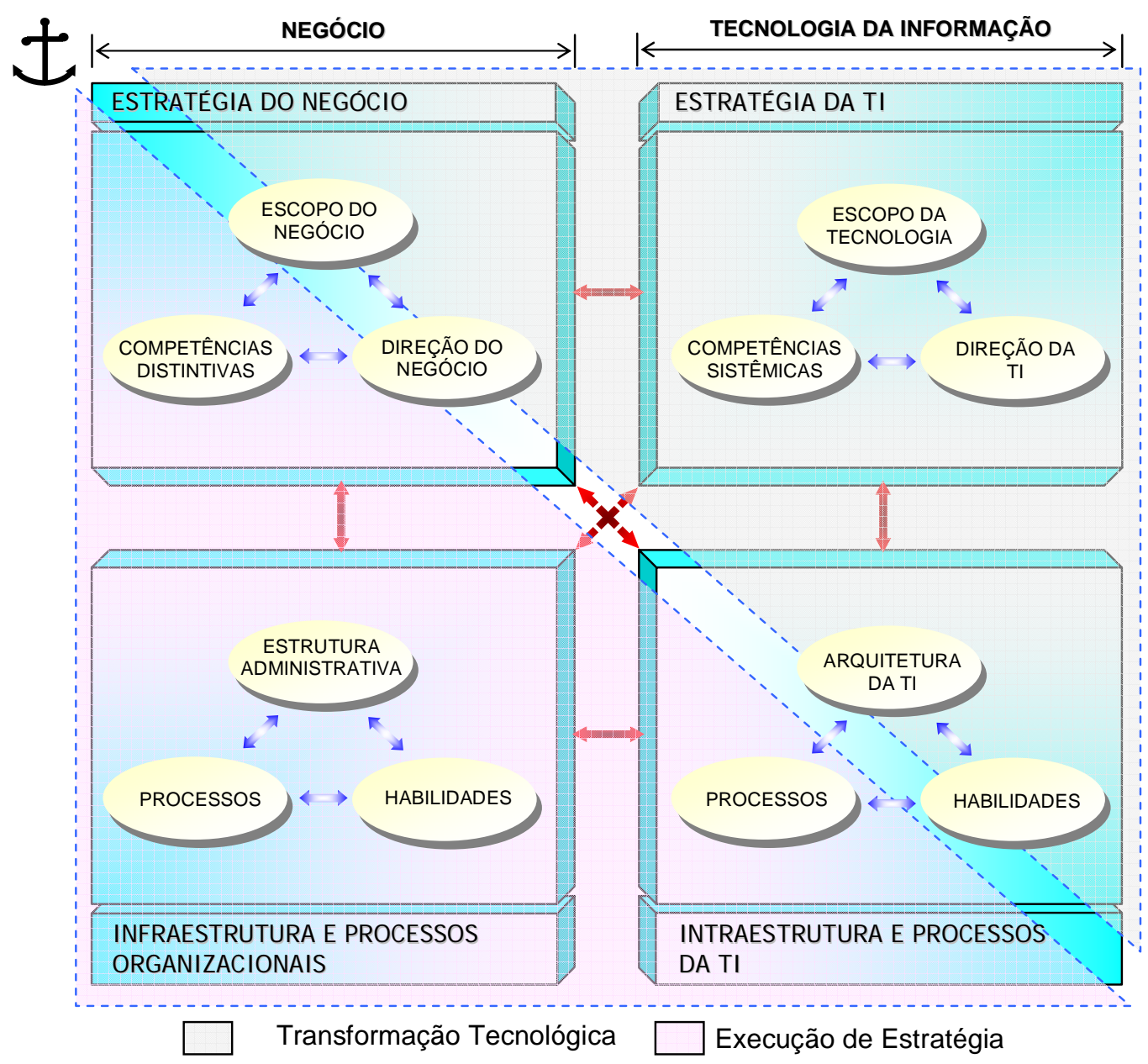

Figura 2.7 - Perspectivas da transformação tecnológica e da execução de estratégia Adaptado de LEWIS; LUFTMAN; OLDACH (1993) 


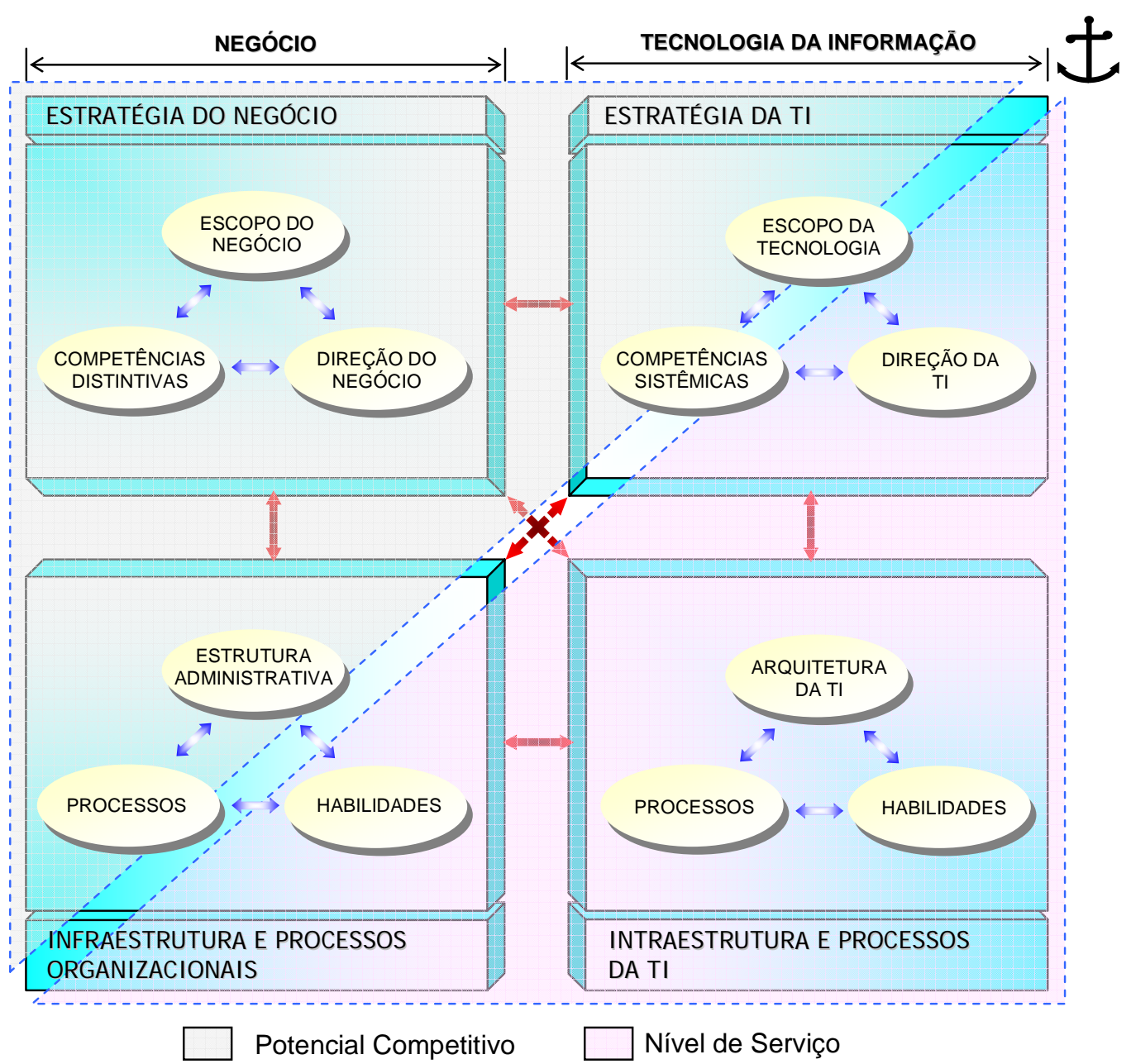

Figura 2.8 - Perspectivas do potencial competitivo e do nível de serviço - Adaptado de LEWIS; LUFTMAN; OLDACH (1993)

Pode-se ainda encontrar em HENDERSON e VENKATRAMAN (1993) que o Modelo do Alinhamento Estratégico identifica as necessidades para especificar dois tipos de integração entre os domínios de Negócio e da TI. O primeiro chamado de “Integração Estratégica” é a ligação entre a Estratégia do Negócio e a Estratégia da TI, refletindo em componentes externos, ou seja, mais especificamente, se trata da capacidade de funcionalidade da TI, de forma a apoiar a estratégia do negócio. Esta capacidade é particularmente importante, mostrando como a TI emergiu como uma fonte importante de vantagem estratégica para a empresa. O segundo tipo, nomeado como “Integração Operacional”, retrata das transações com os domínios internos correspondentes, isto é, a ligação entre Infraestrutura e Processos Organizacionais. 
Este tipo realça a criticidade de assegurar a coerência interna entre as exigências organizacionais e as expectativas e, a capacidade de entrega dentro da função de TI.

Outro aspecto a ser considerado por LEWIS; LUFTMAN; OLDACH (1993) é que a vantagem competitiva e a vantagem estratégica são dois imperativos em uma empresa, caso queira sobreviver mediante ao atual mercado, caso contrário tais vantagens podem se tornar rapidamente em necessidades estratégicas e competitivas quando o empreendimento fica para trás de seus competidores. Portanto, a empresa tem de possuir uma medição robusta e defensiva, no qual deve ser supervisionada, sendo que o desenvolvimento da estratégia de TI e o planejamento, não devem acontecer depois que a estratégia de negócio seja produzida.

Ainda se encontra em HENDERSON e VENKATRAMAN (1993) quatro tipos de perspectivas de alinhamento estratégico, contendo a estratégia de negócio ou a estratégia de TI como dois impulsionadores iniciais.

Estratégia do negócio como impulsionadora. As duas primeiras perspectivas apresentadas surgem quando a estratégia do negócio servir como a força motriz.

Primeira Perspectiva: Execução de Estratégia. Na perspectiva de execução de estratégia, ilustrada na figura 2.9, percebe-se a busca de soluções de TI visando uma nova estrutura da empresa, centralizando algumas funções e buscando interação entre as áreas de negócio. As relações entre os três domínios de estratégia do negócio (domínio âncora), infraestrutura organizacional e processos (domínio pivô), e infraestrutura e processos da TI (domínio impactado) estão correlacionadas. Esta perspectiva de alinhamento é, talvez, a perspectiva mais comum e extensamente compreendida como corresponde à visão clássica e hierárquica de administração estratégica. Assim, não é surpreendente que várias metodologias analíticas diferentes estejam disponíveis para fazer esta perspectiva operacional: Fatores Críticos de Sucesso, Business Systems Planning (divulgado pela IBM), Enterprise Modeling, etc. LEWIS; LUFTMAN; OLDACH (1993) reconhecem a necessidade da filosofia top down (“olhar para baixo”) do topo da organização, identificando áreas críticas para o 
sucesso do negócio. A aproximação das áreas de uma empresa é tipicamente um modo no qual o resultado tem apoio de estratégias de informática organizacionais, mas necessariamente não têm influência da informática nas estratégias do negócio. Não surpreendentemente, o papel da liderança executiva, articulando e comunicando a estratégia de negócio é citada freqüentemente como um Fator Crítico de Sucesso. É importante identificar o papel específico da alta administração, a fim de se obter sucesso nesta perspectiva, ou seja, a alta gerência deve fazer o papel do "formulator de estratégia”, articulando a lógica e as escolhas que pertencem à estratégia do negócio. Já o papel do gerente de TI deve ser um “implementador de estratégia”, isto é, aquele que eficaz e efetivamente designa e instrumenta a infraestrutura da TI exigida e os processos que apóiam a estratégia do negócio escolhida. Os critérios de desempenho para avaliar o funcionamento da TI dentro desta perspectiva estão baseados em parâmetros financeiros que refletem um foco de centro de custo.

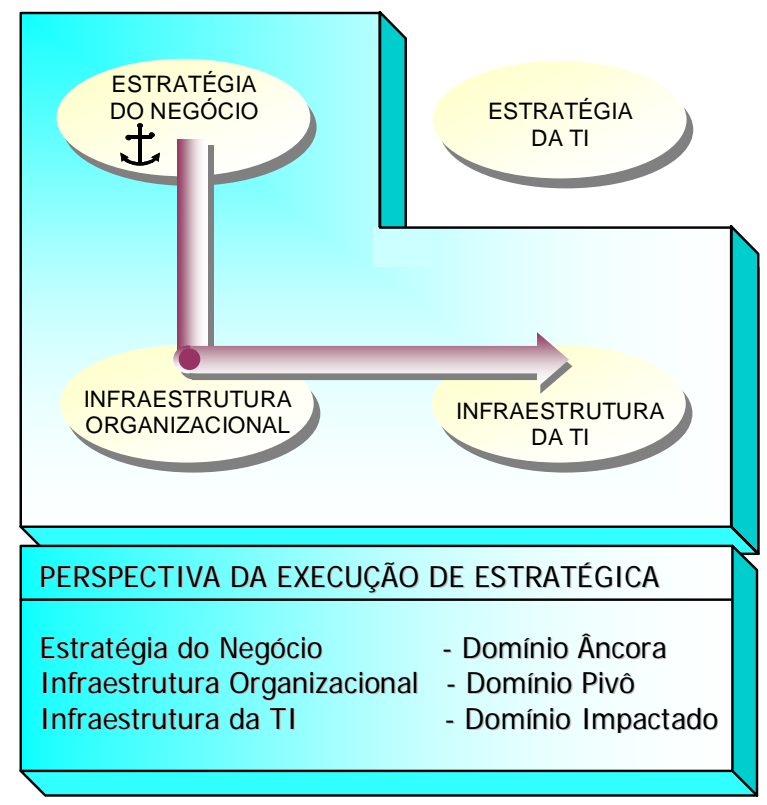

Figura 2.9 - Perspectiva da execução estratégica - Adaptado de LEWIS;

LUFTMAN; OLDACH (1993)

Segunda Perspectiva: Transformação Tecnológica. Na perspectiva da transformação tecnológica, o foco está em estabelecer um ajuste estratégico para a informática. Esta perspectiva, ilustrada na figura 2.10, mostra onde a TI é utilizada para habilitar novas 
estratégias do negócio. Especificamente, executivos precisam entender a relação entre a estratégia do negócio (domínio âncora), a estratégia da TI (domínio pivô) e a infraestrutura e processos da TI (domínio impactado), acarretando em uma tecnologia visionária. Este conceito é ilustrado na perspectiva estratégica na figura 2.7, onde os executivos têm que entender as forças e fraquezas das próprias infraestruturas da TI internas a elas. Em suma, é a necessidade para administrar efetivamente o risco técnico. O executivo não só tem que escolher uma posição efetiva no mercado de tecnologia, mas tem que assegurar que podem ser mudados a tecnologia embutida, os sistemas e as pessoas, de modo a apoiar estas escolhas de tecnologia. Este método também utiliza a abordagem top down (olhar para baixo), no qual avalia as estratégias e as diferentes condições sobre o plano traçado, conforme LEWIS; LUFTMAN; OLDACH (1993). O papel da alta administração executiva nesta perspectiva é prover uma “visão de tecnologia”, no qual deve apoiar melhor a estratégia do negócio escolhida. Já o papel do gerente de TI deve ser o de "arquiteto de tecnologia”, ou seja, o que eficazmente e efetivamente designa e instrumenta a infraestrutura da TI exigida para uma visão consciente em TI. Os critérios de desempenho nesta perspectiva estão baseados em liderança tecnológica, utilizando freqüentemente e comparando a aproximação para avaliar a posição da empresa no mercado de TI. 


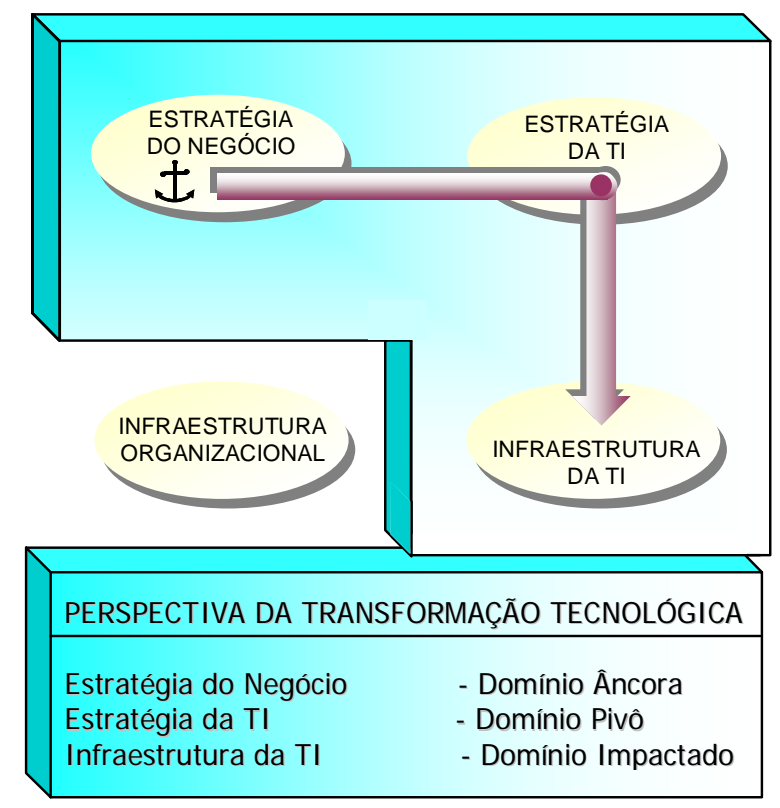

Figura 2.10 - Perspectiva da transformação tecnológica - Adaptado de LEWIS;

LUFTMAN; OLDACH (1993)

Estratégia da TI como impulsionadora. As duas perspectivas finais apresentadas a seguir, surgem quando a estratégia da TI servir como a força motriz.

Terceira Perspectiva: Potencial Competitivo. A visão do potencial competitivo, considerando a visão estratégica da TI, reflete como a tecnologia pode influenciar ou habilitar novas estratégias do negócio (ex.: oportunidades de novos mercados), criando desta maneira uma vantagem competitiva. Esta perspectiva, ilustrada na figura 2.11, relaciona a interação entre a estratégia da TI (domínio âncora), a estratégia do negócio (domínio pivô) e a infraestrutura e processos organizacionais (domínio impactado). O triângulo é também ilustrado na figura 2.8, como a perspectiva do potencial competitivo. É um processo de administração que, explicitamente considera como a informática pode ser aplicada para aumentar a estratégia do negócio e, no final tem-se como resultado a transformação da infraestrutura organizacional. O papel específico da alta gerência para fazer esta perspectiva ter sucesso é tornar um “negócio visionário”, ou seja, um negócio que articula as competências de TI, influenciando na estratégia do negócio. Já o papel do gerente de TI, em contraste, é um “catalisador”, ou seja, um que identifica e 
interpreta as tendências no ambiente de TI, para ajudar os gerentes empresariais a entender as oportunidades potenciais e as ameaças de uma perspectiva de TI. Os critérios de desempenho nesta perspectiva estão baseados na liderança empresarial com medidas qualitativas e quantitativas que pertencem à liderança de produto como parte do mercado, do crescimento e/ou da introdução de novos produtos.

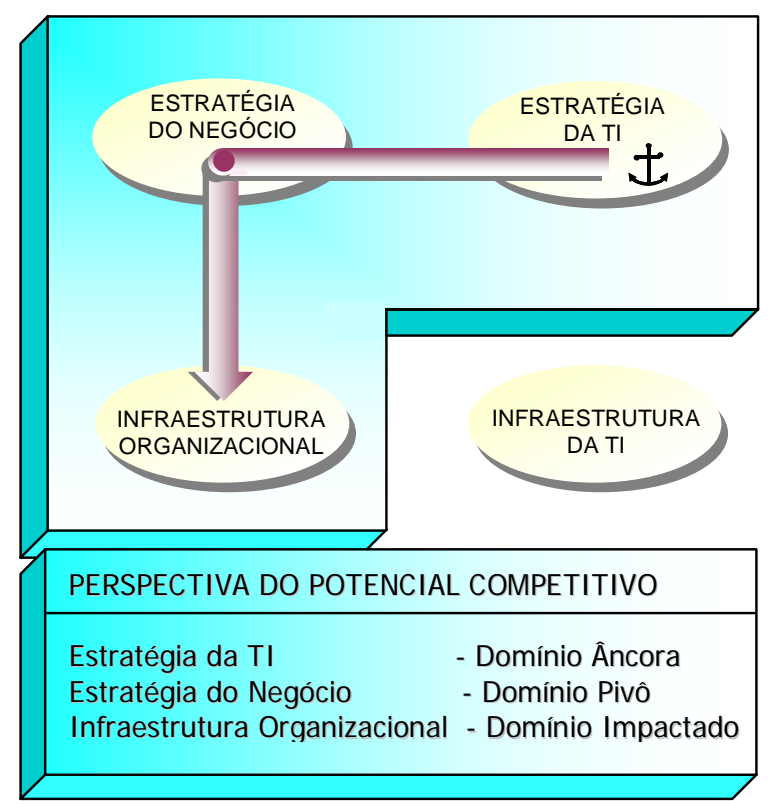

Figura 2.11 - Perspectiva do potencial competitivo - Adaptado de LEWIS;

\section{LUFTMAN; OLDACH (1993)}

Quarta Perspectiva: Nível de Serviço. Nesta perspectiva, ilustrada na figura 2.12, o empreendimento é construído em um ambiente de informática firmemente integrado de classe mundial, no qual focaliza na habilidade de entregar produtos de informática e serviços à organização. Para realizar esta tarefa, os executivos têm que entender a relação entre a estratégia de TI (domínio âncora), a infraestrutura e processos de TI (domínio pivô) e a infraestrutura e processos organizacionais (domínio impactado). O triângulo da figura 2.8 também ilustra a perspectiva do nível de serviço. O gerenciamento estratégico é agora um processo que decide como responder aos desejos e necessidades de um cliente. Neste ambiente, a TI assume responsabilidades como formular políticas e controlar transações interorganizacionais, veiculando contratos de nível de serviço. A extensão de tecnologias coordenada pela 
organização de informática expandiu significativamente com os processadores, as redes, a computação pessoal e automatização de escritórios. Esta aproximação centra em entender a viabilidade da organização de TI para planejar e refletir em estruturas variáveis e tendências. A introdução de comitês dirigentes para definir prioridades é um exemplo de uma decisão desta perspectiva. O papel específico da alta gerência é de fazer esta perspectiva ter sucesso, chamado de "priorizador", no qual articula como melhor alocar os recursos escassos dentro da organização e do mercado de TI. O papel do gerente de TI, em contraste, possui uma "liderança executiva”, com as tarefas específicas de fazer com que o serviço interno tenha sucesso dentro das diretrizes operacionais da alta administração. Os critérios de desempenho desta perspectiva estão baseados na satisfação total do cliente obtida através de medidas qualitativas e quantitativas, utilizando referências internas e externas do empreendimento.

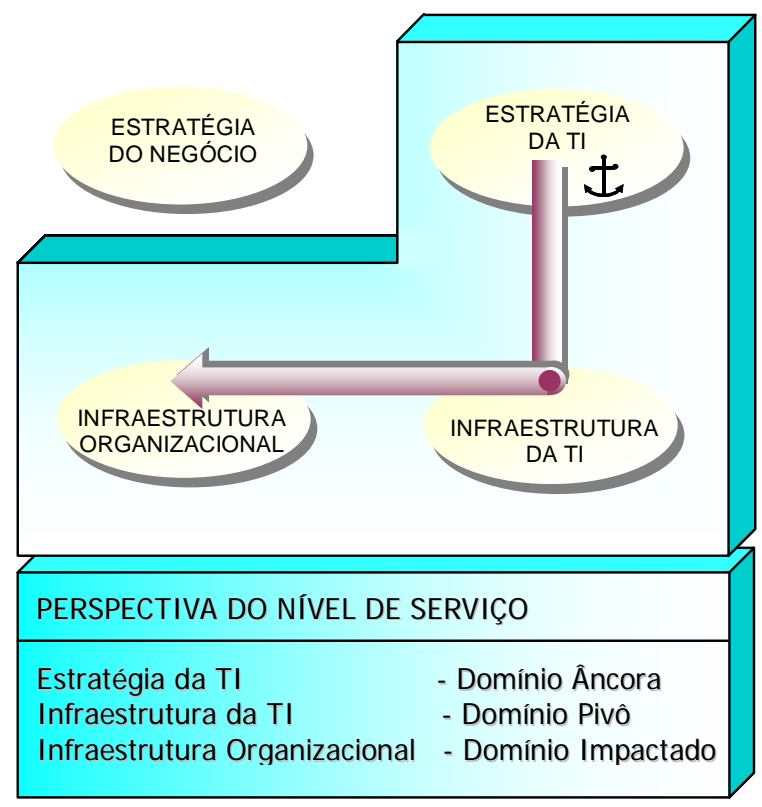

Figura 2.12 - Perspectiva do nível de serviço - Adaptado de LEWIS; LUFTMAN; OLDACH (1993)

A tabela 2.2 e a figura 2.13 resumem as características destas quatro perspectivas. 
Tabela 2.2 - Características das perspectivas do alinhamento estratégico

\begin{tabular}{|c|c|c|c|c|}
\hline PERSPECTIVA & IMPULSIONADORA & $\begin{array}{c}\text { PAPEL DA ALTA } \\
\text { DIREÇÃO DA } \\
\text { EMPRESA }\end{array}$ & $\begin{array}{c}\text { PAPEL DA DIREÇÃo } \\
\text { DE TI }\end{array}$ & $\begin{array}{c}\text { CRITÉRIOS DE } \\
\text { DESEMPENHO }\end{array}$ \\
\hline $\begin{array}{c}\mathbf{1} \\
\text { EXECUÇÃO DE ESTRATÉGIA }\end{array}$ & $\begin{array}{c}\text { Estratégia de } \\
\text { negócios }\end{array}$ & $\begin{array}{c}\text { Formulador de } \\
\text { estratégias }\end{array}$ & $\begin{array}{c}\text { Implementador de } \\
\text { estratégias }\end{array}$ & Centro de custo \\
\hline $\begin{array}{c}\mathbf{2} \\
\text { TRANSFORMAÇÃo } \\
\text { TECNOLÓGICA }\end{array}$ & $\begin{array}{c}\text { Estratégia de } \\
\text { negócios }\end{array}$ & Visão de tecnologia & $\begin{array}{c}\text { Arquiteto de } \\
\text { tecnologia }\end{array}$ & $\begin{array}{c}\text { Liderança } \\
\text { tecnológica }\end{array}$ \\
\hline $\begin{array}{c}\mathbf{3} \\
\text { POTENCIAL COMPETITIVO }\end{array}$ & Estratégia de TI & Negócio visionário & Catalizador & $\begin{array}{c}\text { Liderança } \\
\text { empresarial }\end{array}$ \\
\hline $\begin{array}{c}\mathbf{4} \\
\text { NÍVEL DE SERVIÇO }\end{array}$ & Estratégia de TI & Priorizador & Liderança executiva & $\begin{array}{c}\text { Satisfação total do } \\
\text { cliente }\end{array}$ \\
\hline
\end{tabular}

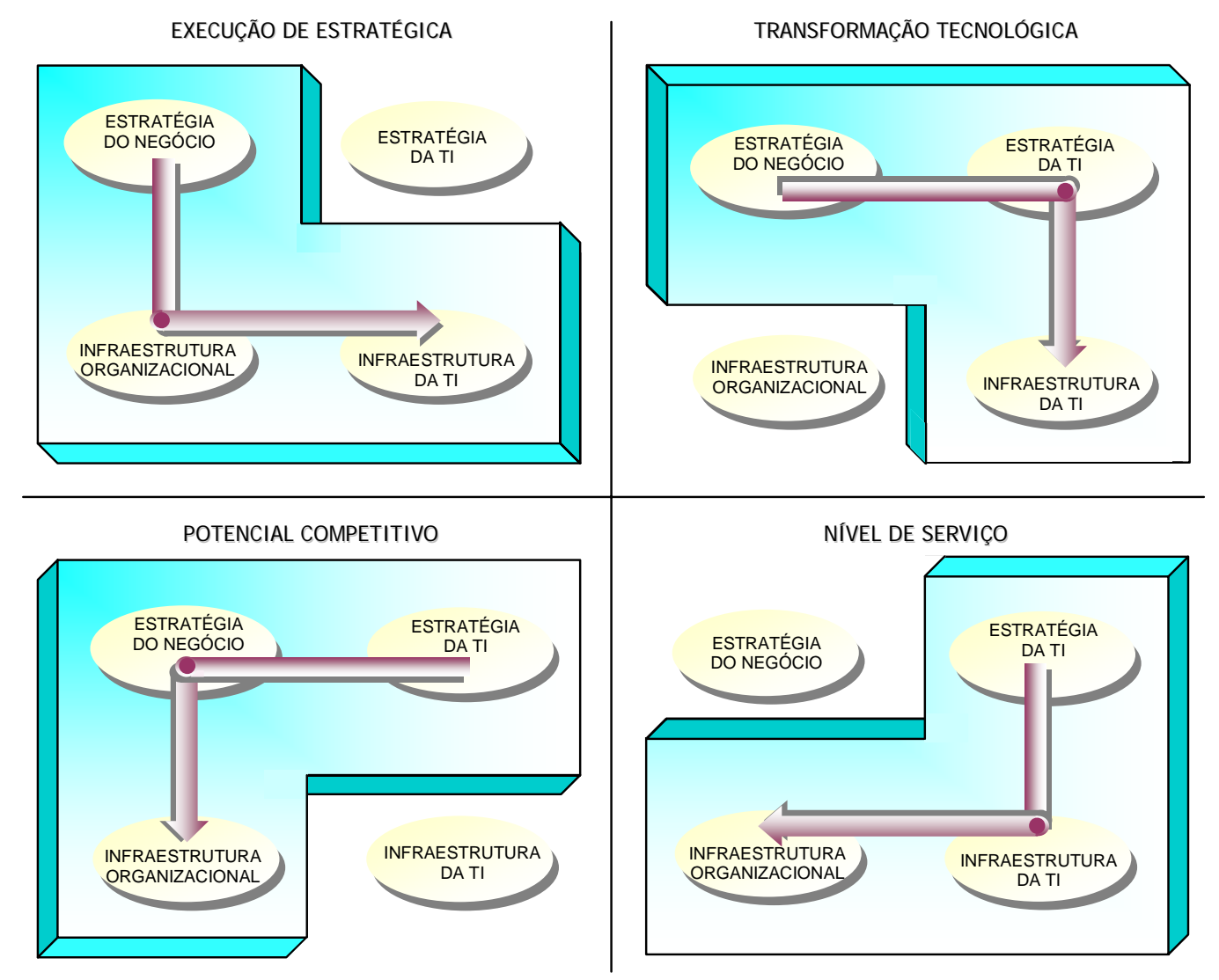

Figura 2.13 - Perspectivas do alinhamento estratégico - Adaptado de HENDERSON e VENKATRAMAN (1993) 


\subsection{Escada de avaliação}

As decisões acerca do desenvolvimento de sistemas de informação nas empresas geram expectativa de um retorno positivo nos investimentos. Portanto, a aplicação da TI e seus objetivos são de extrema importância, devendo-se empregar métodos de avaliação satisfatórios conforme certos tipos de aplicação da TI. Considerando a diversidade abundante de classificações de organizações e suas aplicações de TI, à tarefa de selecionar o método de avaliação mais apropriado, torna-se difícil e limitada quanto à sua aplicabilidade.

Diante deste cenário, três características em comum surgem com utilidades limitadas:

- A primeira característica está relacionada com a evolução das aplicações de TI no tempo, ou seja, sugerir que as organizações sigam um plano lógico, seqüencial e “determinístico”. NOLAN (1979) foi um dos pioneiros que estabeleceu um modelo da evolução/ crescimento da TI na empresa, onde este sugere que haja um padrão de despesa da TI, formando uma curva em "S" de orçamentos da TI contra o tempo. Cada seção da curva tem certas características em termos de tipo de aplicação, estilo de administração e controle de despesas da TI. Porém o processo muitas vezes não é ordenado estritamente, pois organizações mais avançadas hoje ainda escolhem desenvolver aplicações baseadas em redução de custos.

- A segunda característica está relacionada às implicações estratégicas da TI em lugar de sua administração. Após o modelo de NOLAN (1979), McFARLAN (1984) desenvolveu o “Grid Estratégico”, mencionado neste trabalho no item 2.2, no qual consiste de uma matriz 2 X 2 que compara a dependência atual em TI com a importância competitiva futura da TI, tendo como resultado o posicionamento estratégico da organização. Porém, FARBEY; LAND; TARGETT (1995), baseados em pesquisas, afirmam que muitas empresas falharam na aplicação de TI e, o fracasso não foi devido a 
qualquer falta de compreensão estratégica, mas porque os processos de decisão na organização foram inadequados sem uma avaliação da aplicação de TI.

• Já a terceira característica está relacionada com o aumento da compreensão e da consciência, não tendo espaço para a ação sobre as aplicações da TI. No geral, existe a necessidade de tentar superar os obstáculos de levar a compreensão e a consciência a serem postas em prática de ação quanto aos impactos da TI na organização, sendo muito valioso uma ação orientada.

Diante deste cenário, FARBEY; LAND; TARGETT (1995) propuseram um modelo de avaliação denominado "Escada de Avaliação de Benefícios”, no qual é composta de oito degraus, onde cada degrau representa um tipo de mudança e conseqüentemente um tipo de aplicação da TI, conforme tabela 2.3. Cada degrau que se sobe, apresenta um potencial crescente de benefícios, mas também uma crescente incerteza nos resultados, um crescente risco de fracasso e uma dificuldade crescente em convencer os stakeholders pertinentes à aceitarem tais propostas. O foco de avaliação e suas respectivas técnicas apropriadas são diferentes para cada degrau da escada, onde a análise de risco se torna um componente fundamental de avaliação perto do topo da escada. Ao topo da escada, as decisões não requerem somente o consentimento do time da alta gerência, mas sim o envolvimento direto destes membros, uma vez que esta fase compreende em atividades mais complexas, mais difíceis e de alto risco para a empresa, porém com maior potencial de recompensa. Portanto, degraus mais baixos, menor a complexidade e mais objetivos e, degraus mais altos, maior a complexidade e mais subjetivos. 
Tabela 2.3 - Escada de avaliação de benefícios - Adaptado de FARBEY; LAND;

TARGETT (1995)

\begin{tabular}{cl}
\hline$N^{\circ} D O D E G R A U$ & DESCRIÇÃO \\
\hline 8 & Transformação do Negócio \\
7 & Sistemas Estratégicos \\
6 & Sistemas Interorganizacionais \\
5 & Infraestrutura \\
4 & MIS e DSS \\
3 & Sistemas de Valor Adicionado Direto \\
2 & Automação \\
1 & Mudanças Obrigatórias \\
\hline
\end{tabular}

Ainda se encontra em FARBEY; LAND; TARGETT (1995) a explicação de cada degrau da escada de avaliação descrito a seguir em maiores detalhes:

\section{- Primeiro Degrau: Mudanças Obrigatórias}

O degrau de base representa as mudanças forçadas e obrigatórias, ou seja, forçado no senso que a organização tem que mudar para sobreviver em um mercado competitivo e, obrigatório no senso de agentes externos que obrigam mudanças por novas leis ou regulamentos. As decisões são limitadas a escolher alternativas com alguma flexibilidade como cronometrar e o grau para o qual as regras serão implementadas. A tarefa da avaliação é prover avaliações técnicas e de custos de soluções alternativas. Três tipos de mudanças forçadas afetam as decisões dos sistemas de informação:

1. Se um empreendimento está sobre pressão competitiva, talvez porque o concorrente introduziu novos métodos ou foi inovado o atendimento ao consumidor, há a necessidade estratégica de acompanhar os movimentos do concorrente. Um exemplo clássico é o banco 24 horas com caixas eletrônicas de auto-atendimento e semelhantemente, os sistemas de reserva baseados em TI estrategicamente necessários pelas linhas aéreas e pelos negócios de viagem. Uma vez reconhecida à necessidade estratégica, o papel de avaliação é achar o melhor sistema que proverá a capacidade exigida. 
2. Se um empreendimento é forçado a fazer mudanças ou melhorias técnicas específicas, adotando soluções de TI pode-se se tornar um assunto de necessidade tecnológica. As pressões podem surgir de fora da organização ou dentro. Bons exemplos de pressão externa de mudança técnica advêm da redução na deterioração do meio ambiente, onde as montadoras automobilísticas têm, através das leis, que prover novos mecanismos para reduzir a emissão de poluentes, tais como a injeção eletrônica, o catalisador e o módulo de controle do motor (ECM - Engine Control Module). Obsolescência tecnológica provavelmente é o caso interno mais comum de necessidade tecnológica, surgindo quando o custo de manter os sistemas existentes se torna claramente inviável. Novamente o papel de avaliação é achar o "melhor" modo de prover a nova tecnologia.

3. Certas mudanças em sistemas de informação são predeterminadas por regulamentação e legislação. As mudanças requeridas exigem o conhecimento das condições das leis de privacidade e conseqüentemente, o papel de avaliação torna-se fundamental no sentido de avaliar o melhor método para implementar a legislação. Um exemplo é a restrição ao acesso às informações bancárias.

Os métodos mais amplamente utilizados usam a avaliação em critérios clássicos de contabilidade de custos e técnicas de mensuração de trabalho para avaliar os custos das soluções alternativas. Porém, problemas que originam da incerteza de identificar os custos precisos da inovação tecnológica fazem o processo de escolha perigoso, podendo resultar em escolhas baseadas em falsa análise e conseqüente preparação inadequada.

\section{- Segundo Degrau: Automação}

Representa a aplicação de TI projetada para substituir métodos existentes com o intuito de reduzir custos, automatizando rotinas existentes e processando geralmente grandes volumes de cargas de trabalho repetitivo. De maneira geral, provê pouca aproximação de novos negócios, bem como não avaliam o produto ou 
serviço, tendo conseqüentemente pouco impacto na rentabilidade do negócio. Porém, a automatização pode ter efeitos mais importantes:

1. Reduzindo a margem de custo de um negócio pode ser um fator estratégico importante, podendo prover vantagem competitiva. A rede de supermercados é um exemplo.

2. Aumentando a produtividade, em particular dos profissionais qualificados, tem-se um aumento significativo na capacidade da empresa, bem como na administração do crescimento. O setor bancário pode ser citado como um exemplo, no qual hoje controla imensamente mais transações com menos mão de obra, comparado ao passado.

Os benefícios neste degrau estão diretamente atribuídos à substituição dos métodos mais velhos pela tecnologia mais nova. O foco de avaliação está ligado à eficiência e os métodos de avaliação mais apropriados baseiam-se em mensuração de trabalho clássico e organização \& técnicas de métodos, complementadas por alguns métodos de pesquisa operacionais (simulação e modelagem).

Vale ressaltar que, enquanto para muitas organizações este tipo de aplicação provê a justificação principal para o investimento em sistemas baseados em TI, em muitos casos tem desapontado devido ao custo subestimado, negligenciando as estimativas, como os custos de coordenação e diagnóstico.

\section{- Terceiro Degrau: Sistemas de Valor Adicionado Direto}

O terceiro degrau é representado por aplicações que não só reduzem custos, mas adicionam valor diretamente, freqüentemente realizando atividades antes das quais não eram possíveis, considerando certas melhorias e alguns aspectos de desempenho empresarial que já havia sido identificado como "preciosidades". O valor adicionado é diretamente atribuível ao sistema da TI, tendo como resultado o aumento na margem da empresa ou o crescimento significativo na fatia de mercado. 
Muitas aplicações que automatizam processos existentes e também provêem novas características que somam valor estão classificadas neste degrau.

Um exemplo comum é o sistema de processamento de pedidos, no qual proporciona para as empresas pequenos detalhes de compras prévias, acrescentando valor para o cliente através de um melhor atendimento, bem como para o fornecedor.

Porém, é importante salientar que o valor adicionado não necessariamente pode beneficiar a empresa, mas sim somente ao consumidor, devido ao mercado altamente competitivo. Assim, pode-se citar como exemplo os caixas automáticos de bancos (ATMs - Automatic Teller Machines) que acrescentam valor ao sistema bancário fazendo serviços de banco disponível para seus clientes vinte e quatro horas por dia, no qual distribuíram aquele valor adicionado diretamente ao consumidor, e não em geral para os bancos.

O valor adicionado é um exemplo de eficácia crescente, no qual o foco de avaliação é analisar que valor é somado e como aquele valor poderia ser distribuído, porém calcular freqüentemente o impacto da nova capacidade torna-se uma tarefa difícil. Assim os bancos não previram o impacto que os ATMs causariam, pois devido a disponibilidade constante dos serviços do banco (o BANCO 24 HORAS) os clientes encorajaram-se a freqüentar mais vezes aumentando significativamente o número total de transações para o banco.

As técnicas clássicas de contabilidade de custos e técnicas de mensuração de trabalho não provêem estimativas úteis. Provavelmente o melhor método de avaliação é utilizar técnicas experimentais, como testes de campo e projetos pilotos, no sentido de prover uma melhor avaliação do impacto da inovação.

- Quarto Degrau: Sistemas de Informações Gerenciais (Management Information Systems - MIS) e Sistemas de Suporte à Decisão (Decision Support Systems - DSS) 
Este degrau representa aplicações que provêem informação para planejar, controlar e decidir. Portanto, são dirigidos freqüentemente aos níveis mais altos da gerência. Embora o MIS e o DSS são conceitualmente diferentes, estes são colocados no mesmo degrau, pois apresentam problemas semelhantes em termos de avaliação.

Nos últimos anos, houve uma alteração na ênfase do processamento transacional e da automatização de procedimentos existentes para a utilização da tecnologia, a fim de melhor a produtividade de gerentes e outros profissionais especializados. Os sistemas, principalmente o MIS e o DSS, proporcionam aos gerentes uma melhor informação que lhes permitem elevar o controle do negócio e tomar decisões baseadas em informações mais seguras, precisas, oportunas ou apresentadas em forma facilmente utilizada.

Alguns sistemas nesta categoria provêem uma infraestrutura que permite a administração e coordenação de suas atividades em uma gama mais ampla, no qual estes sistemas exigem uma avaliação mais aprofundada no processo decisório. Um exemplo é a informação de marketing que a administração de um supermercado obtém pela introdução de sistemas de ponto de venda eletrônicos, onde ajuda na administração, na melhoria do espaço em gôndolas, assegura menores estoques e reduz desperdícios.

As características comuns de aplicações que representam o quarto degrau são que provêem instalações que só somam valor se os usuários das instalações tiverem a capacidade ou a oportunidade de tirar vantagem deles. O fato que ter uma informação específica melhor não é nenhuma garantia que produtividade administrativa será melhor ou terá um valor adicionado.

O foco de avaliação deste degrau se torna uma auditoria do valor adicionado potencial moldada talvez por alguns tipos de medida de probabilidade ou análise do “melhor ou pior caso”. Uma alternativa às vezes utilizada é solicitar aos usuários que avaliem o valor de uma melhor informação, fazendo-os “pagar” por ela. Contanto que o pagamento seja feito de recursos reais, este é um dispositivo útil para centros 
de lucro, por exemplo. Porém, esta prática não garante à organização um ganho real, uma vez que este mecanismo pode transferir a responsabilidade simplesmente de quem decide pela implementação do novo sistema.

Na prática, é difícil obter evidências que a capacidade administrativa aumente apreciavelmente, porém vários estudos tentam associar produtividade administrativa com investimentos em TI, onde se acredita que exista uma pequena evidência que a capacidade administrativa é aumentada pelo uso de TI. O ponto a ser enfatizado é que o aspecto mais importante para o desempenho da gerência é a sua competência e habilidade, e não o melhor sistema de apoio de decisão.

\section{- Quinto Degrau: Infraestrutura}

É representado por investimentos que provêem uma capacidade geral, mas que podem não ser associados a qualquer aplicação específica. Visa criar uma base na qual podem ser implementadas aplicações que geram valor adicionado subseqüente, não produzindo nenhum benefício direto e imediato ao negócio. Um bom exemplo é a introdução da automatização em escritórios, no qual a expectativa é possuir redes de área locais, acesso para instalações externas de bancos de dados e correio eletrônico, a fim de gerar ações de resposta frente à concorrência. Na prática, muitas destas instalações são utilizadas como sistemas informais (utilização do correio eletrônico em mensagens pessoais no ambiente profissional) ao lado dos sistemas formais, porém projetados contemplando esta situação na maioria das organizações.

Aplicações específicas relacionadas a infraestrutura para apoiar uma gama de atividades futuras podem possuir uma complexidade nos sistemas, uma quantia de informação exigida e uma objetividade nas decisões maiores neste degrau em relação aos degraus já mencionados. Entretanto, tais investimentos do tipo infraestrutura são vistos como necessário para a empresa, a fim de responder rapidamente a qualquer movimento do mercado e outras pressões, embora caracterizados por consideráveis incertezas quanto ao impacto que a TI terá. 


\section{- Sexto Degrau: Sistemas Interorganizacionais}

Representado por sistemas que cruzam limites organizacionais, ou seja, sistemas que são compartilhados por duas ou mais organizações. Embora os sistemas são compartilhados colaborando para todas as organizações, o valor adicionado necessariamente não é compartilhado igualmente por todos os participantes.

Pode-se citar como exemplo deste degrau, os sistemas interorganizacionais mais amplamente discutidos o EDI - Electronic Data Interchange. Caracterizado basicamente por um sócio dominante com a condição de obter a maior parcela de ganhos. Para o sócio dominado, o uso do EDI pode ser classificado como um sistema obrigatório, porém na prática o colaborador dominado pode obter benefícios econômicos, entretanto é o sócio principal que espera obter o maior valor do sistema.

A avaliação de sistemas inter-organizacionais tem que envolver todos os parceiros, até mesmo os parceiros “dominados”. Unindo tais sistemas, as organizações compartilham de uma maneira padronizada dos benefícios, porém diminuem sua liberdade e flexibilidade. Para sistemas inter-organizacionais o foco de avaliação é equilibrar a perda de independência total contra os benefícios potenciais de sistemas compartilhados e o valor das parcerias suportadas pelos sistemas, onde muitos destes impactos são difíceis de avaliar.

\section{- Sétimo Degrau: Sistemas Estratégicos}

O sétimo degrau representa o uso estratégico da TI. EARL (1989) apud FARBEY; LAND; TARGETT (1995) afirma que o uso estratégico deste degrau está definido da seguinte maneira:

$\checkmark$ Ganhar vantagem competitiva;

$\checkmark$ Melhorar a produtividade e o desempenho;

$\checkmark$ Introduzir novos modos de administrar e organizar;

$\checkmark$ Desenvolver novos tipos de negócio.

A realização do uso estratégico da tecnologia requer um alinhamento muito íntimo entre a estratégia empresarial e o planejamento de sistemas de informação, 
conforme destacado no Modelo do Alinhamento Estratégico por HENDERSON; VENKATRAMAN (1993) e LEWIS; LUFTMAN; OLDACH (1993). Porém, isto requer em troca que os sistemas de informação sejam vistos pela alta administração da empresa como um recurso estratégico que tem o papel de tornar efetivos os planos de negócio. Conseqüentemente, o uso da TI deste modo é caracterizado por inovação e liderança, mas também traz consigo níveis elevados de riscos.

No setor público onde a vantagem competitiva foi talvez menos utilizada, o uso estratégico da TI inclui combinar as metas estratégicas de prover serviços melhorados ao público, com responsabilidade e controle de administração do serviço.

É importante ressaltar que muitos dos estudos de casos clássicos de sistemas que foram de importância estratégica para diversas empresas, começaram como degrau dois ou degrau três e, subseqüentemente provou que eles tiveram mais que uma significação operacional. O sucesso desses casos, a um nível estratégico, foi devido ao fato que, a alta administração percebeu a importante vantagem que os novos sistemas estavam oferecendo e de certo modo a reorganização do negócio ao redor da TI.

Mais recentemente, as empresas têm buscado agir de forma pró-ativa, alinhando os planos da TI com a estratégia de negócio, a fim de adquirir as vantagens que os estudos de casos clássicos apontam. Na prática, ainda há pequena evidência que tais empresas tiveram mais êxito pelo uso da TI no alcance de suas metas, porém, o real valor desse alinhamento está evitando investimentos mal sucedidos.

Calcular o retorno dos investimentos realizados utilizando a TI é difícil, por outro lado a não utilização de um processo de avaliação, pode levar a perdas de importantes oportunidades ou persuadir em iniciativas posteriormente catastróficas. Nota-se porém que, alguns métodos de avaliação como custo / benefício e retorno sobre o investimento (ROI) são raramente satisfatórios para alcançar decisões em investimentos estratégicos, pois realmente alguns casos de benefícios estratégicos teriam fracassado em qualquer teste baseado em custo / benefício e ROI. 
A avaliação da aplicação da TI a fim de prover benefícios estratégicos, deve ser baseada em uma ampla análise da situação do negócio e, em particular focar na situação competitiva, juntamente com uma análise de riscos, podendo ser o melhor modo para avaliar se investir ou não em uma aplicação que julga-se advir benefício estratégico. Talvez um critério fosse que os projetos devem mostrar um benefício operacional claro, até mesmo se tais benefícios não podem ser justificados em uma base puramente de ROI.

\section{- Oitavo Degrau: Transformação do Negócio}

O último degrau da escada é representado pelas aplicações de TI que permitem mudanças, transformando as empresas. As transformações do negócio são sempre estratégicas na sua concepção, porém freqüentemente são forçadas em uma empresa por falta de sucesso econômico, ou por causa de mudanças no ambiente econômico, no qual a empresa necessita de uma reação rápida se quiser sobreviver no mercado, ou porque o empreendimento perdeu sua habilidade para competir prosperamente, devido talvez por causa de estratégias deficientes da administração.

Um bom exemplo de transformação forçada, citada pelos autores, foi a transformação na indústria automobilística americana, competindo diretamente com a indústria automobilística japonesa e outros competidores globais. Este acontecimento se realizou devido a um processo não somente de mudanças tecnológicas, mas também de mudanças na prática de administração, bem como no relacionamento entre indústria e cliente.

A gama de benefícios depende da transformação como um todo, ou seja, o benefício surge da sinergia advinda de todas as atividades, onde se encontra freqüentemente uma série de mudanças complexas, no qual utiliza-se a TI para apoiar ou facilitar tais mudanças. Por exemplo, a introdução do processo Just In Time (JIT) em uma indústria envolve diversas mudanças logísticas do negócio, como administração de inventário, armazenamento, ordem de compra, distribuição e comunicação e assim por diante, onde o uso efetivo da TI é um componente fundamental nesta transformação. 
A ênfase de avaliação está no conjunto como um todo e não somente em um componente, sendo a TI um dos fatores importantes na escolha das soluções tecnológicas mais apropriadas para habilitar as principais mudanças a ser levadas à prática.

A figura 2.14 resume os oito degraus da escada de avaliação de benefícios.

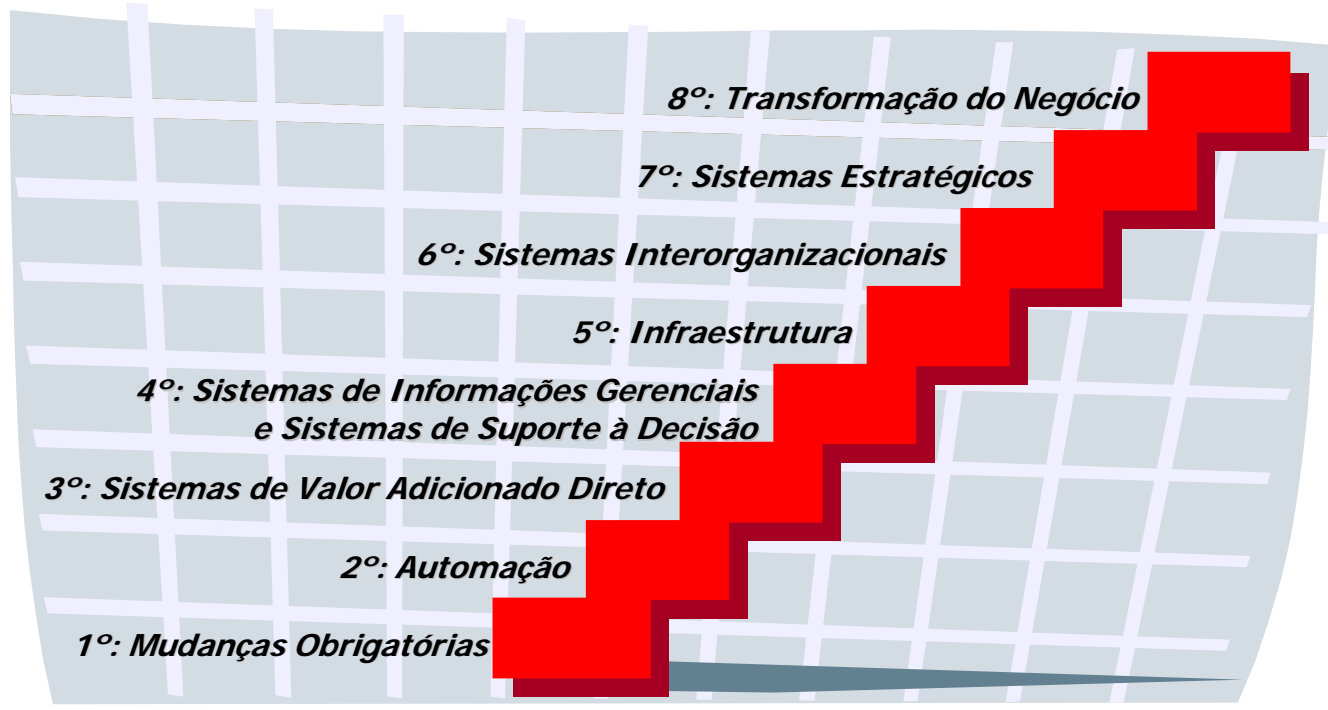

Figura 2.14 - Escada de avaliação 


\section{O PROCESSO DE DESENVOLVIMENTO DE NOVOS PRODUTOS DE UMA INDÚSTRIA AUTOMOBILÍSTICA}

Nos dias atuais, com o efeito da globalização e conseqüente aumento da competitividade entre as empresas, o sucesso no lançamento de novos produtos tem se tornado um dos principais fatores de competitividade, no qual, principalmente as indústrias automobilísticas vêm buscando a melhoria de seus processos de desenvolvimento de novos produtos, com maior rapidez, eficiência e eficácia, trazendo impactos diretos em custos, qualidade, satisfação do consumidor e vantagem competitiva., conforme entre outros, CUSUMANO; NOBEOKA (1992) e WHEELWRIGHT; CLARK (1992).

\subsection{Conceituação do desenvolvimento de novos produtos}

O processo de desenvolvimento de novos produtos, ou mais comumente conhecido no ambiente internacional como NPD - New Product Development, encontra-se na interface entre a empresa e o mercado, cabendo a ele: desenvolver um produto que atenda às expectativas do mercado, em termos de qualidade total do produto, desenvolver o produto no tempo adequado, ou seja, mais rápido que os concorrentes, e a um custo de projeto compatível. Além disso, deve-se também assegurar a manufaturabilidade do produto desenvolvido, ou seja, a facilidade de produzi-lo, atendendo às restrições de custos e qualidade (FLORENZANO, 1999).

Segundo CLARK; FUJIMOTO (1991), tem-se que: “desenvolvimento de produto é o processo pelo qual uma organização transforma dados sobre oportunidades de mercado e possibilidades técnicas em bens e informações para a fabricação de um produto comercial”.

KAMINSKI (2000) também conceitua o processo de NPD “como um conjunto de atividades envolvendo quase todos os departamentos da empresa, que tem como objetivo a transformação de necessidades de mercado em produtos ou serviços economicamente viáveis. O processo de desenvolvimento de produtos 
engloba desde o projeto do produto (fase principal) até a avaliação do produto pelo consumidor, passando pela fabricação”.

Pode-se dizer que projetar é a atividade principal de quem desenvolve produtos, no qual todo e qualquer desenvolvimento envolve sempre fatores econômicos, humanos, ambientais e principalmente tecnológicos, variando a importância relativa destes fatores conforme a comunidade a que se destina (figura 3.1).

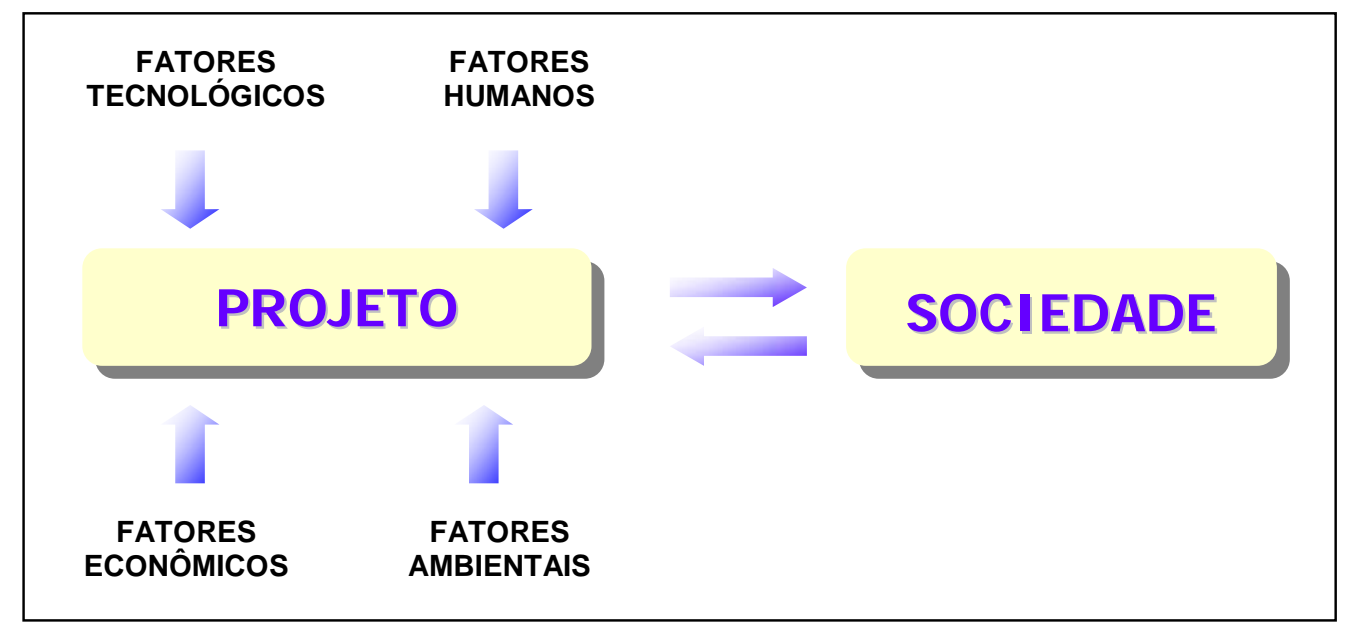

Figura 3.1 - Fatores de influência no projeto - Adaptado de KAMINSKI (2000)

\subsection{O NPD}

O lançamento de um produto novo no mercado, para a maioria das empresas, principalmente no setor automobilístico, não é uma atividade rotineira e sim, o resultado de um esforço que pode durar um tempo significativo e envolver quase todos os setores funcionais da empresa. Uma característica organizacional muito específica da atividade de desenvolvimento é que cada projeto pode apresentar problemas, dificuldades e históricos muitos particulares. Além disso, é uma atividade que influencia o trabalho de praticamente todas as pessoas da organização, já que o novo produto será produzido, vendido e controlado por todos os seus setores. Sendo assim, é válido considerar dois aspectos relevantes para desenvolver um enfoque sobre o NPD: o conceito do processo e o fluxo de informações (AMARAL, 1997). 
O conceito do processo auxilia na visualização das organizações em termos das atividades ou como um conjunto de atividades. O processo é um conjunto de atividades ordenadas num tempo e espaço com entradas e saídas claramente definidas. Partindo desta visão deixa-se de lado a clássica divisão das organizações em termos físicos e funcionais e melhora-se a visão em termos de integração e eficiência da operação das empresas (DAVENPORT, 1994).

O fluxo de informações se faz importante à medida que geram entradas e saídas de conhecimento na análise de desenvolvimento do produto, fluxo de criação, comunicação e utilização das informações desenvolvidas.

Tomando-se como base o fluxo de informações, levando em conta a definição de NPD segundo CLARK; FUJIMOTO (1991) descrita anteriormente, pode-se esclarecer as ligações críticas dentro da organização e entre a organização e o mercado, permitindo identificar os aspectos essenciais de desenvolvimento do produto em um ambiente de competição e interação da empresa com o ambiente externo.

Desse modo, pode-se posicionar o processo do NPD dentro do ambiente da empresa e sua relação com os outros processos. Esta visualização está esquematizada na figura 3.2 . 


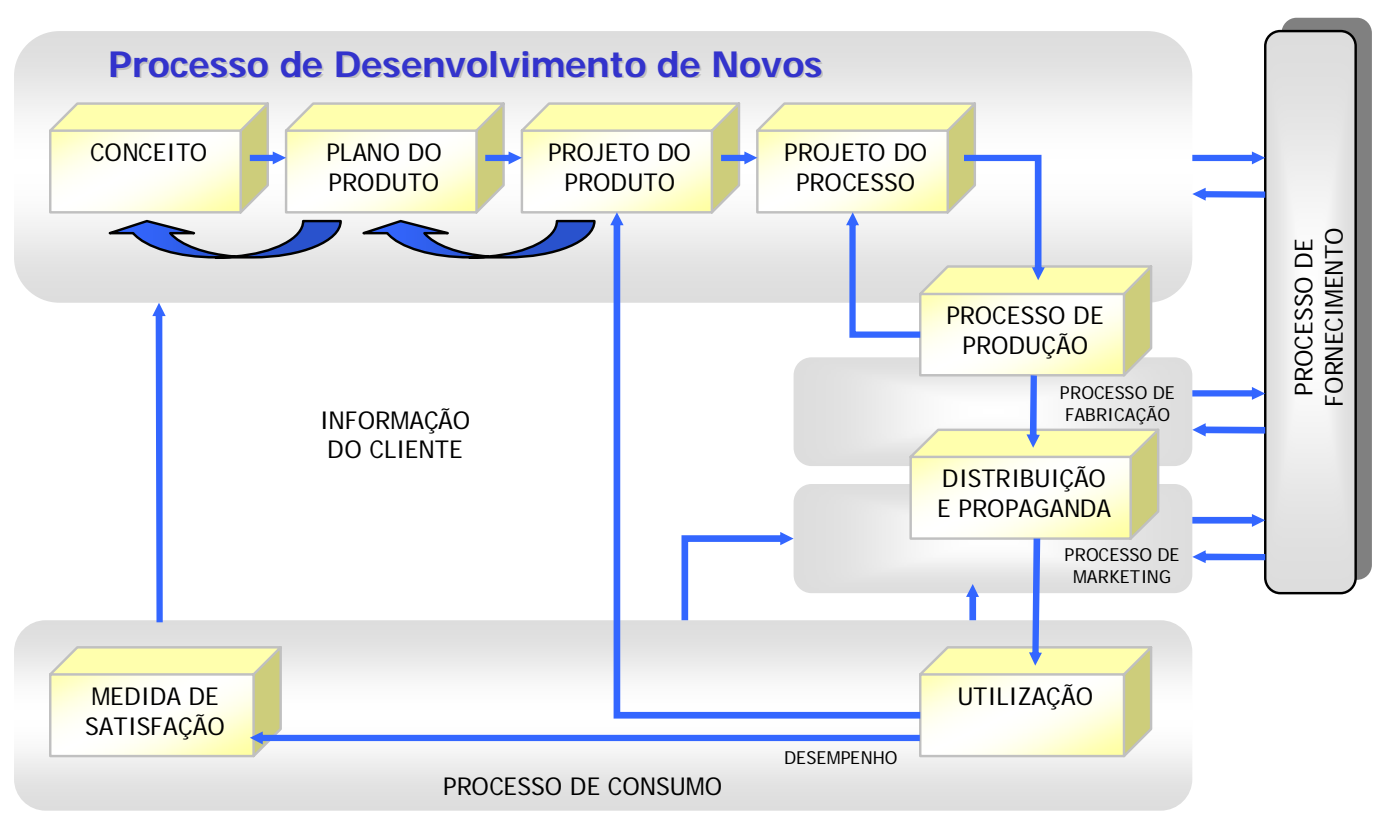

Figura 3.2 - Modelo de empresa com base no fluxo de informações - Adaptado de CLARK; FUJIMOTO (1991)

As linhas da figura representam o fluxo de informações e as caixas os processos. O processo de NPD foi destacado por ser o objeto de interesse. O “processo de consumo” inserido na figura, o qual na verdade não faz parte da organização, tem um papel importante já que o desenvolvimento alimenta-se daquilo que nele foi gerado. Segundo CLARK; FUJIMOTO (1991), as atividades de desenvolvimento são desempenhadas tentando "simular" o consumo. Assim, torna-se importante não deixar de fora esta parte do fluxo de informações, que completa a ligação entre os processos.

O processo de consumo compreende a distribuição de produtos, informações e serviços a ele relacionados e da utilização do produto pelo consumidor. Na sua entrada estão as informações de marketing e do produto em si e suas saídas são informações sobre o desempenho do produto no mercado e as experiências e necessidades dos consumidores com relação à sua utilização.

Quanto ao processo de desenvolvimento, suas saídas são entradas do processo de fabricação, que irá produzir os produtos em escala comercial. 
Com relação ao processo de fornecimento, este interage com todos os outros processos anteriores, recebendo informações sobre suas necessidades e alimentando os mesmos com matérias-primas, insumos e bens para a produção. Ainda segundo CLARK; FUJIMOTO (1991), no processo de desenvolvimento de produto de empresas mais próximas dos fornecedores, o processo de fornecimento tem uma atuação mais ampla que a de abastecer com bens físicos, incorporando também a de proporcionar informações / soluções técnicas e serviços colaborando nas atividades de desenvolvimento do produto, possuindo um fluxo complexo de saídas e entradas entre os dois processos.

Pode-se visualizar a interação entre os dois processos por meio da figura 3.3, onde nela aparecem os fluxos de informações relativos ao desenvolvimento de produto no fornecedor, na montadora e o mercado. Nota-se que, o fornecedor pode auxiliar o cliente até mesmo desde o conceito do produto, porém nem todos os fornecedores irão apresentar este nível de relacionamento, podendo se responsabilizar por apenas uma parte menor do desenvolvimento do sistema. 


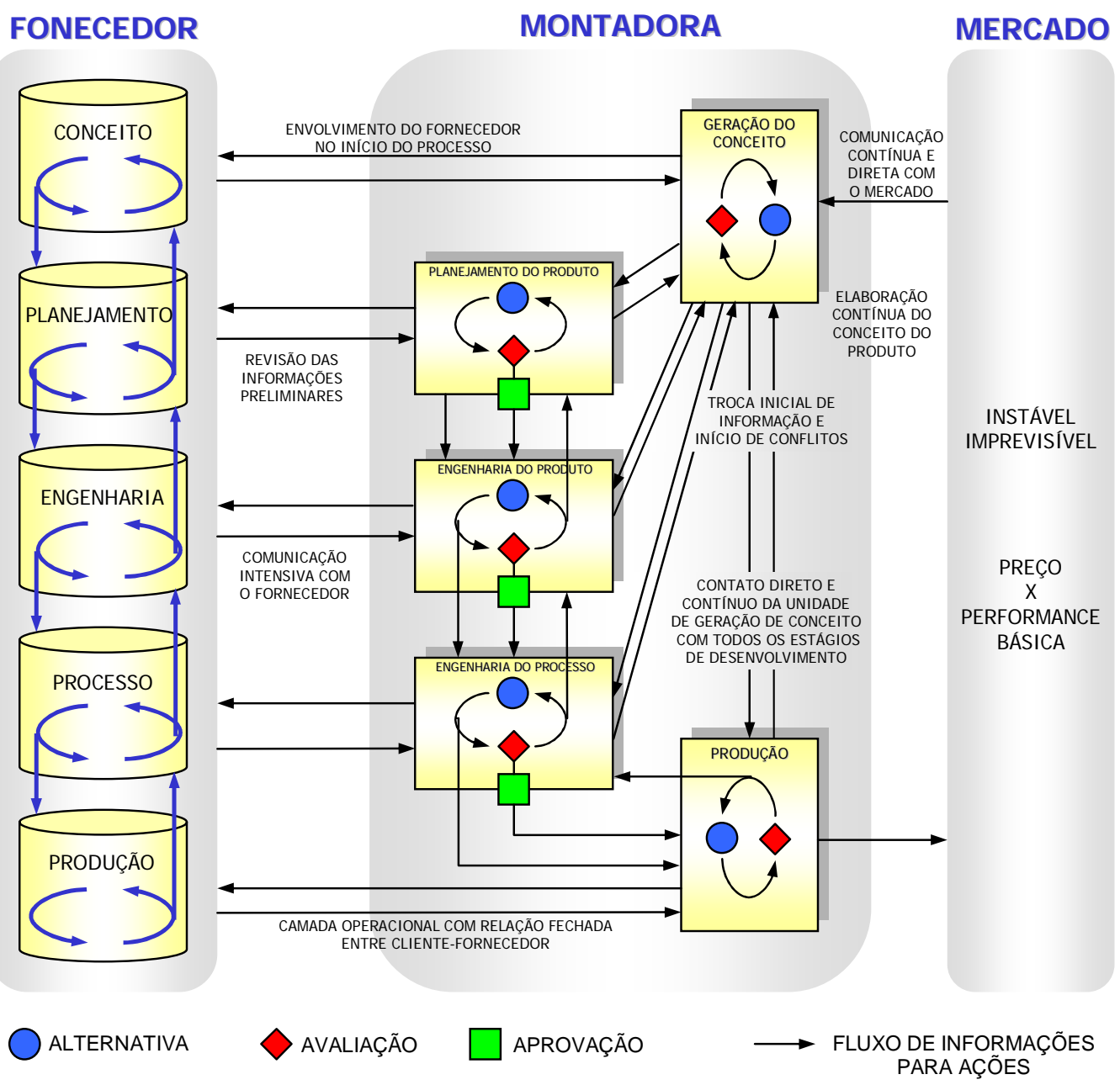

Figura 3.3 - Interação dos fornecedores no processo de NPD - Adaptado de CLARK; FUJIMOTO (1991)

\subsection{Características específicas do NPD}

Algumas características próprias do NPD em relação aos outros processos industriais, as quais considera-se de maior importância são: “a natureza de ciclo de resolução de problemas” e “a consistência de detalhes”.

- A natureza do ciclo de resolução de problemas: Uma particularidade do NPD em relação aos outros processos é a natureza de suas atividades baseadas em um ciclo de "projetar-construir-testar". As atividades de um projeto compreendem, em geral, em quatro etapas básicas: reconhecer o problema, 
gerar alternativas, analisar a viabilidade de cada alternativa e definir a solução mais adequada (figura 3.4). Esta característica do processo de desenvolvimento é que torna extremamente importante a integração e sobreposição das fases entre as atividades, pois cada uma delas está em contínua mudança podendo influenciar a outra (CLARK; FUJIMOTO, 1991). Além disso, essa particularidade faz com que o retrabalho nesse processo seja mais tolerado, já que está propagado no meio de alterações consideradas “normais” (TOLEDO, 1994).

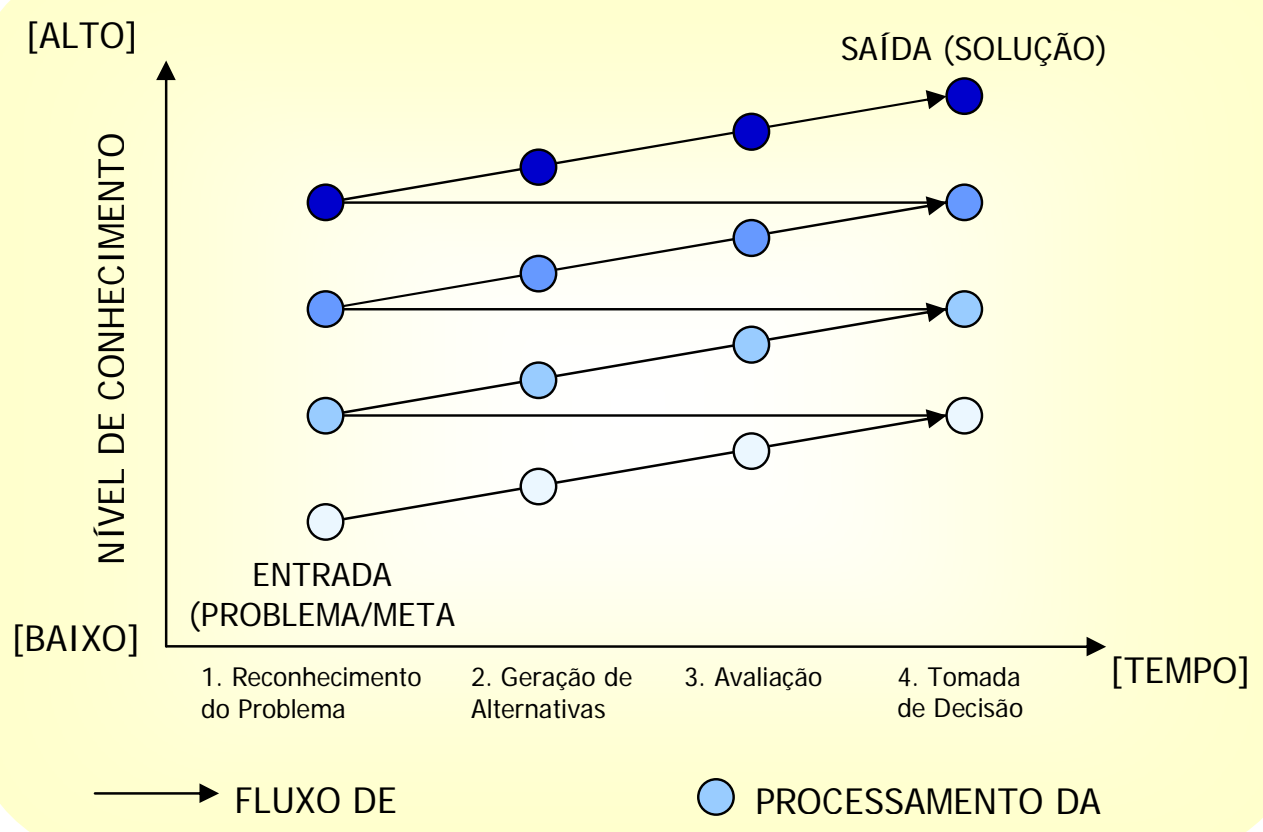

Figura 3.4 - Ciclo de resolução de problemas - Adaptado de CLARK;

\section{FUJIMOTO (1991)}

- A consistência de detalhes: CLARK; FUJIMOTO (1991) consideram ainda um aspecto importante para o NPD a consistência dos detalhes, ou seja, a harmonia entre o todo e cada detalhe que um bom projeto deve possuir, a qual implica em uma interdependência entre as pessoas que realizam as diferentes atividades de desenvolvimento. Assim o desempenho do projeto depende tanto da eficiência na resolução de cada problema como também do 
gerenciamento da integração entre as atividades para as quais os ciclos estão sendo desempenhados.

\subsection{Fases do NPD}

As fases gerais que compõem o NPN são apresentadas a seguir, com intuito de possibilitar uma melhor compreensão do processo de desenvolvimento de produtos.

Segundo AMARAL (1997), entrar em contato com funcionários da área de desenvolvimento de produto de várias organizações e/ou publicações, e analisar a definição das fases do NPN, pode fazer pensar em termos de fases sólidas e claras, na medida em que as respostas soam bem parecidas. Porém, ao contrário do que possa parecer numa primeira vista, dividir o processo do NPD em fases é arbitrário e relativo, dependendo muito da situação e vantagens em se aplicar tal definição ou, como num caso prático, muito do ramo industrial e da empresa em questão.

Pesquisando a bibliografia, pode-se encontrar alguns exemplos de modelos do NPD, onde neste trabalho é apresentado três modelos com o objetivo de formar um embasamento teórico que procurará suportar o processo do NPD, sendo cada um deles estruturados por fases, porém tendo suas diferenças particulares. O primeiro deles é muito difundido no meio acadêmico sendo de autoria de PUGH (1996). Já o segundo é de autoria de KAMINSKI (2000). E por fim, o terceiro é baseado principalmente nas definições de CLARK \& FUJIMOTO (1991), relatando um processo de NPD tomando-se como base estudos de caso na indústria de autopeças.

Segundo PUGH (1996) o Total Design ou o NPD, como está sendo designado neste trabalho para o desenvolvimento de um produto, é divido em cinco fases: 
口 Mercado (Market)

- Especificações (Specification)

口 Projeto conceitual (Conceptual Design)

๑ Projeto detalhado (Detail Design)

口 Produção (Manufacture)

๑ Vendas (Selling)

O autor considera que este processo possui suas fases seqüenciais e interativas, proporcionando uma retro-alimentação das informações durante todo o processo do NPD, conforme a figura 3.5. Neste contexto, torna-se primordial para o sucesso do projeto a questão de ouvir e interpretar o que o mercado anseia, a fim de traduzir em especificações de projeto e posteriormente desenvolver o projeto do produto, o projeto do processo de fabricação e por fim a estratégia de vendas. 


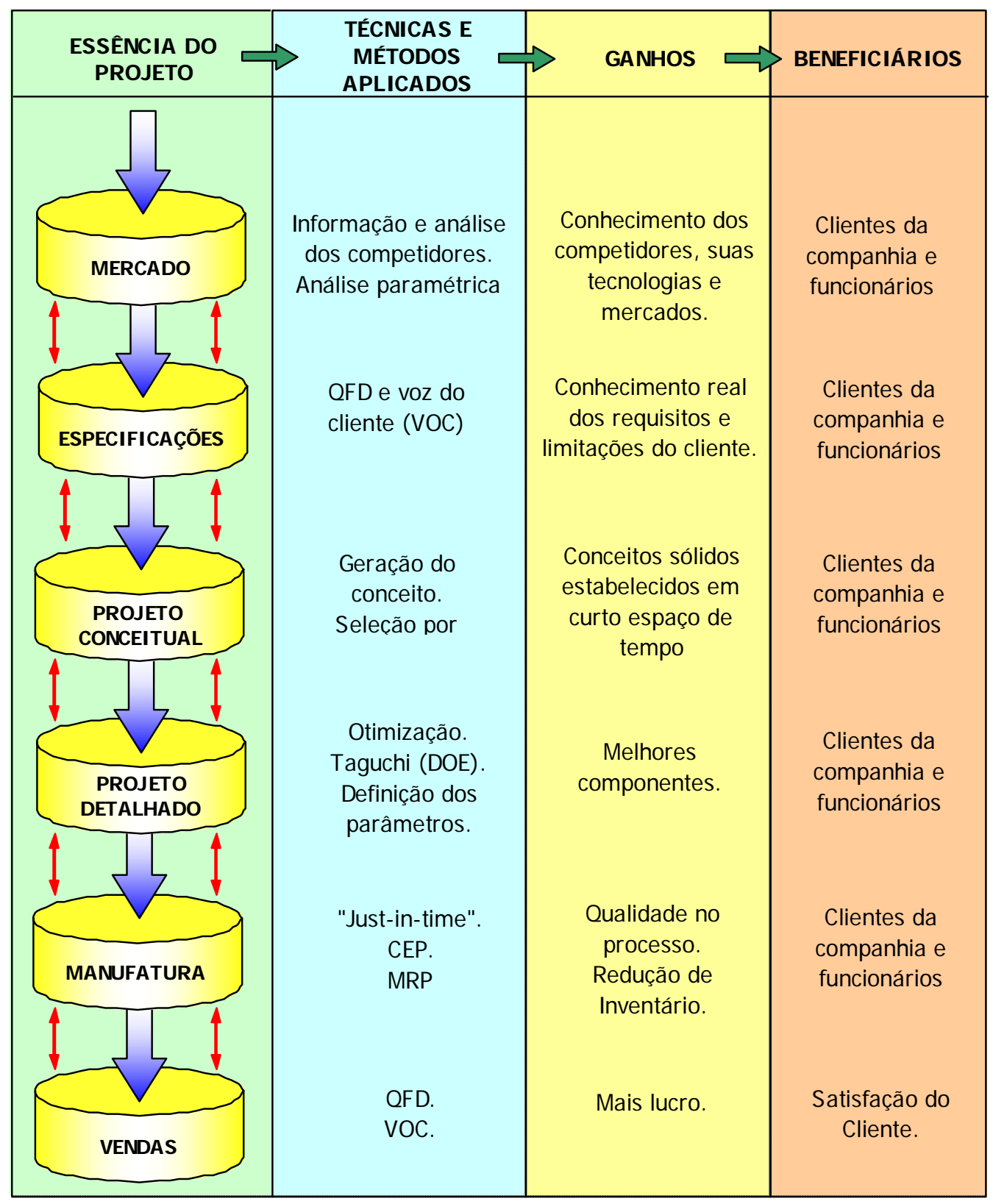

Figura 3.5 - Modelo Total Design - Adaptado de PUGH (1996)

Ainda se encontra em PUGH (1996), a distinção entre dois tipos de modelos de conceito: o “conceito dinâmico” e o “conceito estático”. O conceito dinâmico é caracterizado pela necessidade de se assumir um conceito dentre diversos propostos através da seleção do que melhor se adequa à proposta do projeto. Já o conceito estático é o oposto do conceito dinâmico, onde não há a escolha de um conceito a ser utilizado no projeto, pois este já se encontra definido. Os projetos de automóveis são 
exemplos clássicos de conceitos estáticos, pois pelos próximos anos, um automóvel ainda será constituído por quatro rodas, uma em cada extremidade, um motor, uma transmissão, freios nas rodas, assento de duas a sete pessoas, etc., ou seja, não há a escolha do conceito, pois este já é assumido e suas especificações são sempre determinadas de acordo com a escolha.

KAMINSKI (2000) propõe uma metodologia de trabalho baseada no planejamento operacional, onde a figura 3.6 fornece, como exemplo, informações globais dos setores envolvidos em cada atividade, seus respectivos setores responsáveis pela execução e controle de cada atividade, bem como os pontos de controle do desenvolvimento do produto. Ao se fixar datas para esses pontos de controle, tem-se o cronograma geral e, com base nele pode-se elaborar um cronograma mais detalhado de todo o processo. Com essas etapas realizadas, pode-se verificar o caminho crítico e os cuidados a serem tomados para evitar atrasos desnecessários. Esse conjunto de informações permite ao administrador acompanhar e controlar operacionalmente o NPD, no qual é distribuído pelas seguintes fases:

๑ Viabilidade

๑ Desenvolvimento

๑ Implantação

๑ Lançamento 


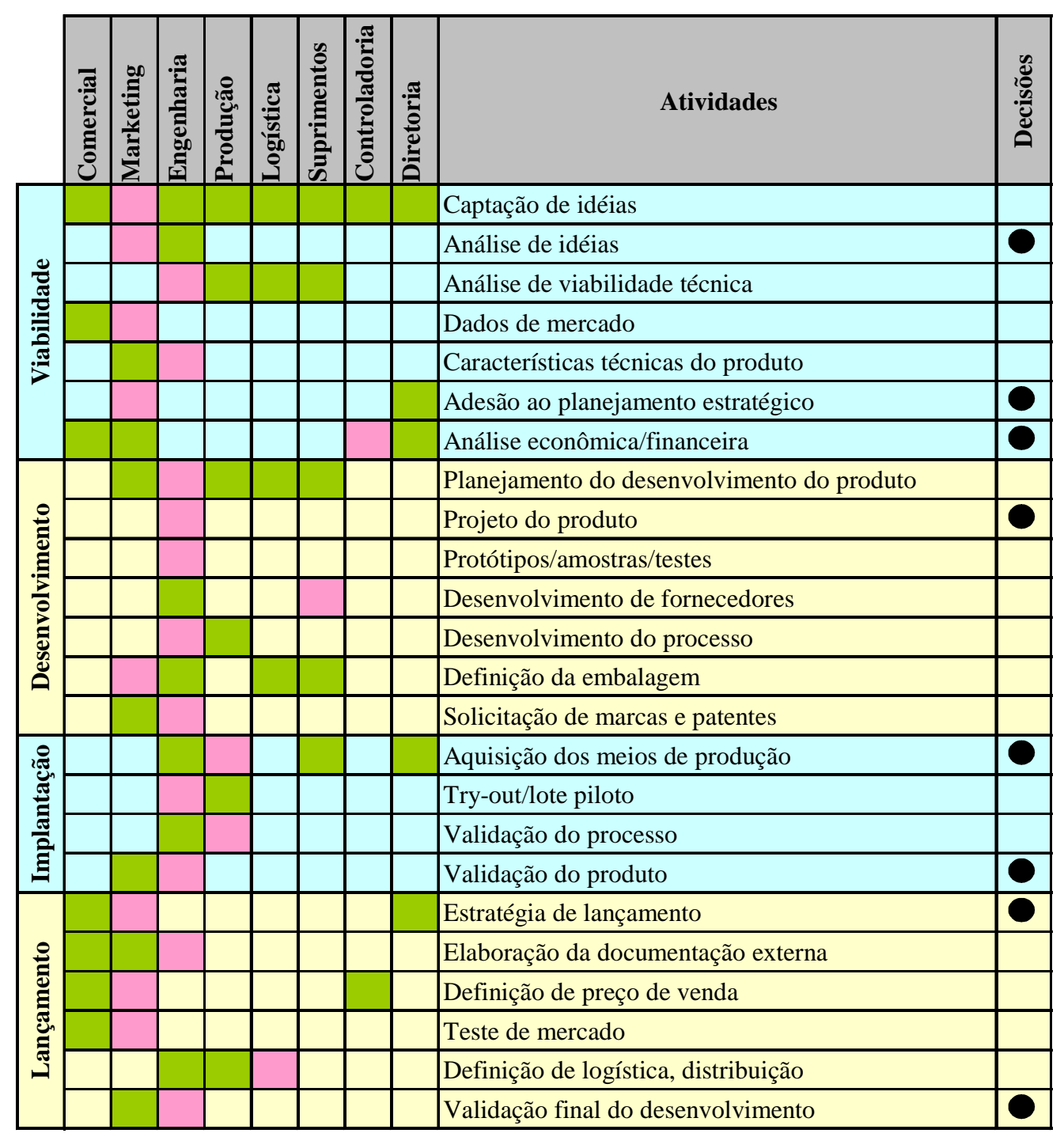

Setor envolvido com a atividade

Setor respensável pela atividade

Pontos de controle no desenvolvimento de produto

Figura 3.6 - Setores envolvidos e responsáveis pelas atividades de desenvolvimento - Adaptado de KAMINSKI (2000)

Baseando-se nos trabalhos de CLARK; FUJIMOTO (1991), WHEELWRIGHT; CLARK (1992) e SILVA (1995) existem basicamente cinco fases distintas, conforme ilustra a figura 3.7, no qual são muito adotadas em estudos, 
bem como na rotina das empresas, porém tendendo cada vez mais na prática, se confundir dada às tendências de integração e sobreposição das mesmas.

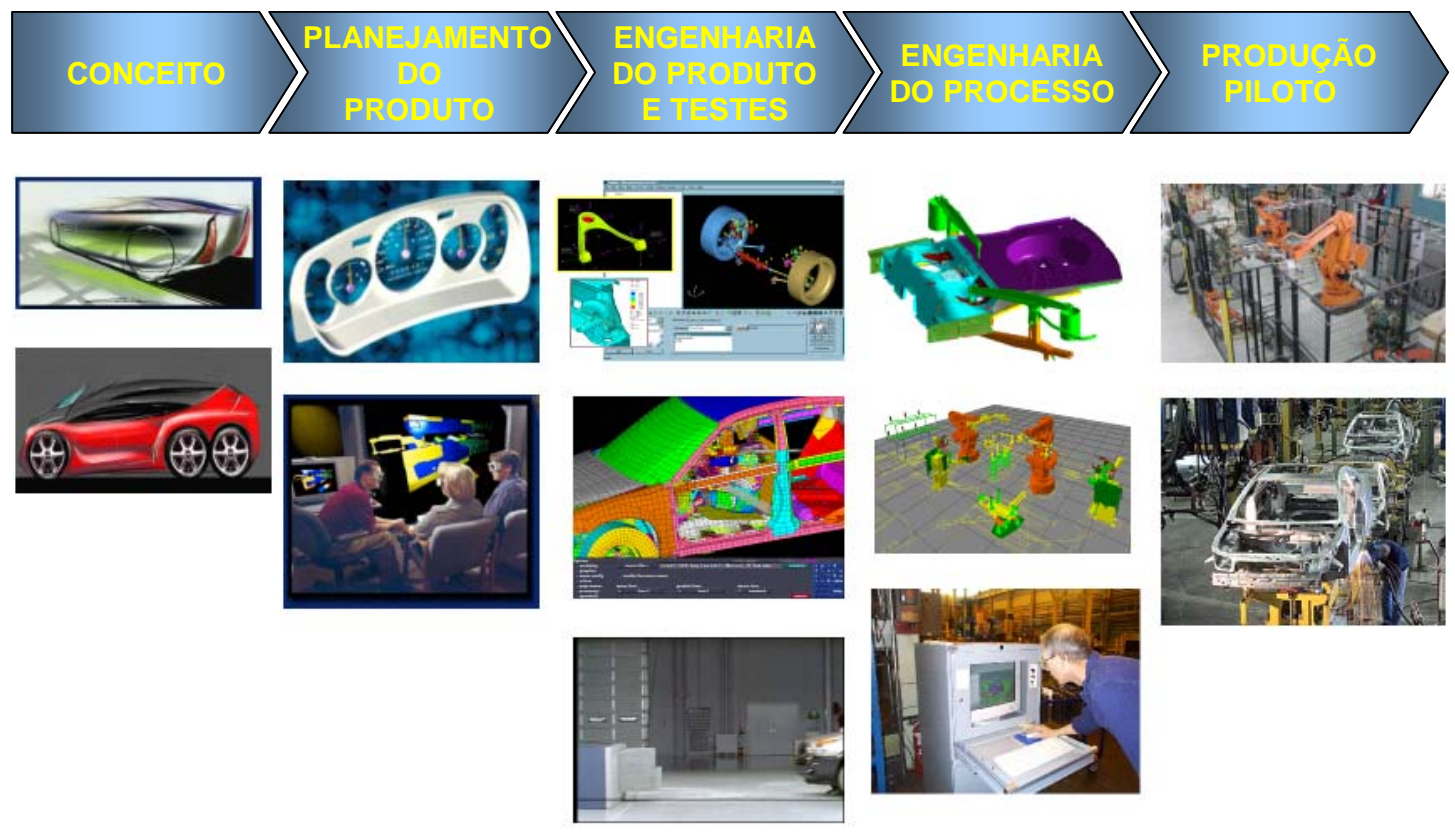

Figura 3.7 - Fases do NPN

a Conceito

Nesta fase as informações sobre necessidades e utilização dos produtos pelos clientes, informações sobre os competidores, tecnologia, riscos, oportunidades tecnológicas, padrões e regras do ambiente são transformadas na definição do produto (figura 3.8). A definição do produto compreende: parâmetros do produto tais como segmento de mercado alvo e a inserção neste segmento; meta de preço e características de funcionalidade; características tecnológicas do produto; a alocação de recursos para o desenvolvimento do mesmo e, podendo ou não, incluir detalhes técnicos mais específicos (BACON et al., 1994).

É a fase inicial do NPN e o seu resultado pode ocasionar um processo de revisão contínua nas demais atividades/ fases. Segundo BACON et al. (1994), esta fase influencia significativamente o sucesso do desenvolvimento 
do produto. A definição do produto é o instrumento que guia o time de desenvolvimento, apontando as características que o produto deve possuir, transmitindo informações sobre o mercado alvo do produto, bem como responsável pelo estabelecimento das prioridades na resolução dos trade-offs que surgem durante a elaboração das especificações do projeto.

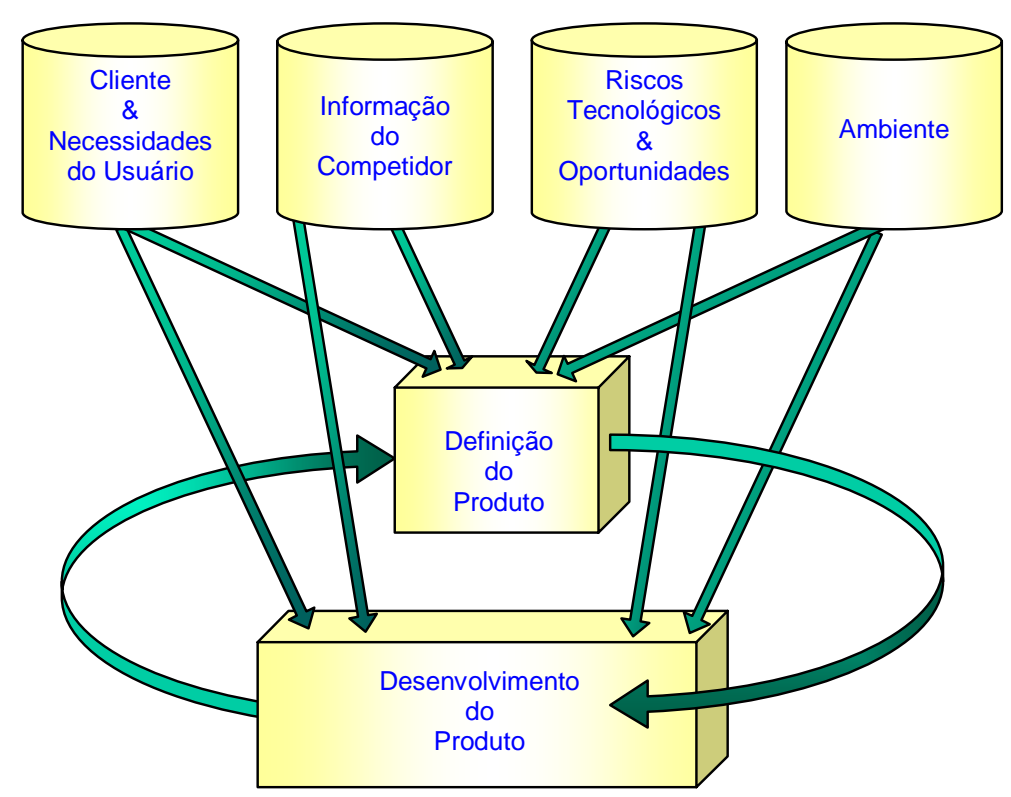

Figura 3.8 - O processo de definição do produto - Adaptado de

BACON et al. (1994)

\section{- Planejamento do Produto}

A fase de planejamento do produto define a execução do projeto e detalha o produto, a partir do que foi estabelecido no conceito, compondo uma base comum de informações para todos os integrantes do processo de desenvolvimento do produto e do projeto. Nesta fase é executada a construção de modelos físicos, tais como mock-ups para a avaliação de estilo e lay-out, que ao seu final tem-se estabelecido todas as condições necessárias para o início efetivo dos cálculos e desenhos finais. Esta fase compreende a documentação básica do projeto do produto (CLARK; FUJIMOTO, 1991). 
- Engenharia do Produto e Testes

Nesta fase tem-se o detalhamento dos itens técnicos do projeto, onde se especifica os requisitos a serem atendidos, através de descrições, desenhos e modelos para todos os sistemas e sub-sistemas. Além disso, elaboram-se os conjuntos modulares, no qual se tem o detalhamento de cada um dos subsistemas, quer sejam fornecidos ou produzidos internamente. Assim, é realizada a decisão make or buy e por conseqüência a seleção de fornecedores/ parceiros. Esta fase apresenta como resultados a geometria global do produto, diversas verificações de interferências através de Digital Mock-Ups (DMU), protótipos em escala natural, desenho e documentação por parte dos fornecedores e a logística de fornecimento.

\section{- Engenharia do Processo}

Esta fase compreende na finalização do desenvolvimento do produto, com a elaboração dos processos de produção e de testes funcionais e de durabilidade. As atividades previstas nesta fase englobam os projetos dos meios de produção, o planejamento de processo, o planejamento da produção em série, a produção de modelos padrões, a liberação de documentação para os sistemas oficiais da empresa e análise dos resultados dos protótipos tanto internos como dos subsistemas dos fornecedores.

- Produção Piloto

Nesta fase inicia-se a produção do produto simulando as condições normais de operação da fábrica, de forma a produzir os primeiros exemplares do produto para teste e realizar os acertos finais no processo de fabricação (CLARK; FUJIMOTO, 1991). Os resultados desta fase compreendem um estreitamento junto aos fornecedores, a homologação dos meios de produção e dos produtos e a preparação de vendas e rede de concessionárias e assistência técnica. O término desta fase é marcado pelo início da série. 
Estas fases estão relacionadas se sobrepondo e interagindo-se continuamente, bem com as pessoas envolvidas no projeto, apesar de uma seqüência lógica de entradas e saídas, de acordo com a interdependência dos diferentes tipos de atividades.

Os três modelos apresentados, conforme já mencionado possuem suas similaridades no aspecto de estruturação por fases, tendo no caso de PUGH seis fases, no caso de KAMINSKI quatro fases e no caso de CLARK \& FUJIMOTO cinco fases. Por outro lado, em relação às diferenças encontradas, principalmente voltadas a aplicação no ambiente automotivo, pode-se afirmar que o modelo de PUGH vem ganhando credibilidade, porém ainda mais restrita ao meio acadêmico, proporcionando ênfase especial à fase inicial do projeto, conseguindo captar com confiabilidade e transformar as necessidades dos clientes em requisitos de projeto. Já o modelo exposto por KAMINSKI é apresentado de maneira genérica, onde não apresenta características exclusivas do setor automobilístico, porém ajuda no entendimento do NPD, bem como sua eficácia está diretamente ligada a qualidade do planejamento operacional. E por fim, o modelo de CLARK \& FUJIMOTO, por ser concebido dentro das indústrias de autopeças, é o que apresenta estar mais focado na visão automotiva, o que explica o maior destaque dado neste item, devido ao enfoque deste trabalho.

\subsection{Dimensões básicas da estrutura referencial para o NPD}

CLARK; FUJIMOTO (1991) afirmam que a competição industrial que está focalizada fortemente no processo de NPD pode ser avaliada por três parâmetros básicos: qualidade, tempo e produtividade, que devem ser otimizados para capacitar uma empresa na sua habilidade de atrair e satisfazer seus clientes, aumentando a competitividade de seus produtos, levando o NPD ao centro do jogo de competição entre as empresas, situação essa, comum inclusive no meio automobilístico. Estes três parâmetros desempenham um papel particular no melhoramento global do desempenho e competitividade no NPD, uma vez que, para se obter um 
balanceamento otimizado do produto desenvolvido, as empresas devem buscar a excelência integrada nestes três parâmetros.

Porém, para as empresas se prepararem para atingir essa excelência, é necessária uma compreensão do NPD como um todo, fazendo com que os esforços para melhoria e gestão deste processo não sejam desperdiçados. WHEELWRIGHT; CLARK (1992) perceberam esta necessidade e apresentaram uma proposta para a compreensão da complexidade e criticidade do NPD, baseada na análise de seis dimensões (figura 3.9) que juntas representam e auxiliam a percepção do processo, suas interfaces e nuances, facilitando a sua gestão e abrindo o caminho para possíveis melhorias e/ou modificações. Embora estas dimensões interajam entre si para criar um padrão detalhado de desenvolvimento de produtos, elas envolvem diferentes questões e assim necessita-se a compressão individual de cada uma.

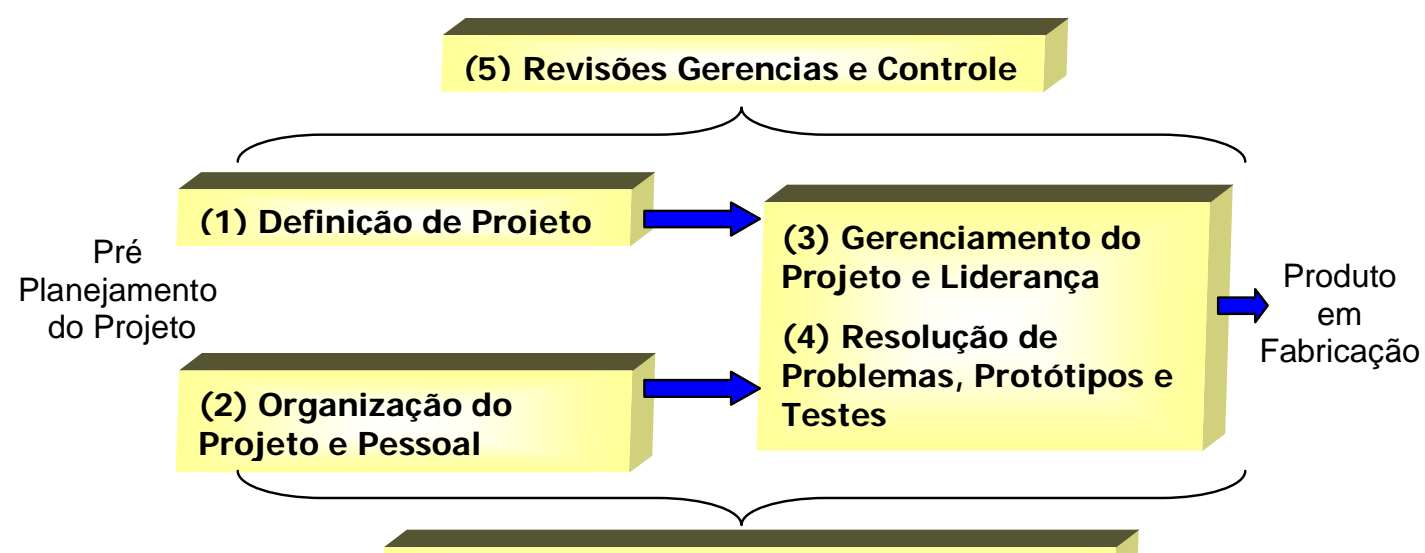

(6) Correcões / Modificacões de Proieto

Figura 3.9 - Dimensões básicas de uma estrutura referencial para compreensão do NPD - Adaptado de WHEELWRIGHT; CLARK (1992)

\section{Definição do Projeto}

Esta dimensão define como a empresa configura o escopo do seu projeto, determinando os limites do projeto e suas interfaces com a empresa, resultando em propostas e objetivos bem definidos. A principal atividade é o 
desenvolvimento do conceito e definição, com a utilização de informações internas e externas à empresa. Geralmente esta dimensão tem como característica principal a determinação de metas, objetivos e comprometimento de recursos.

A estruturação das atividades desta dimensão tais como a geração de idéias, o desenvolvimento do conceito e o estudo de mercado são destacados por MAHAJAN; WINDY (1992) em uma pesquisa onde estudou os modelos de desenvolvimento de produtos nas empresas. O estudo focou na prática da indústria atual, analisando quais modelos e métodos utilizados, suas falhas e desejos de melhoria, trazendo como resultados implicações para criadores, fornecedores e usuários do NPD.

\section{Organização do Projeto e Pessoal}

Esta dimensão trata das pessoas alocadas ao projeto e sua forma de organização, ou seja, são consideradas questões como localização física, estrutura organizacional, responsabilidades individuais, treinamento e relacionamento com áreas de suporte.

BROWN; EISENHARDT (1995) destacam a importância desta dimensão, no qual citam três aspectos relacionados aos times que exercem influência no desempenho do processo do NPD: a composição da equipe, o processo de trabalho e a organização do trabalho.

\section{- Gerenciamento do projeto e liderança}

Esta dimensão caracteriza o papel dos líderes de projeto, bem como o seu gerenciamento, ou seja, como as tarefas são seqüenciadas e administradas. Considera-se o estabelecimento de papéis e responsabilidade para a liderança do projeto de modo que as atividades sejam executadas da melhor maneira possível. Também considera como as atividades são agrupadas e divididas em fases e 
como o trabalho é administrado e controlado nestas fases. Além disso, define os pontos de verificação e marcos utilizados para sinalizar o final de cada fase.

A importância desta dimensão é ressaltada por BROWN; EISENHARDT (1995), no qual afirmam que a atuação do gerente afeta o desempenho do processo tanto em termos de qualidade, rapidez e produtividade como o conceito do produto. GRIFFIN (1997) também ratifica, dizendo que o envolvimento e compromisso da alta gerência com o NPD são fundamentais para o desempenho do processo, especialmente no fornecimento de recursos e fundos adequados.

\section{- Resolução de problemas, testes e protótipos}

Esta dimensão envolve a natureza dos problemas, sejam gerenciais ou técnicos e a maneira como os protótipos e testes são utilizados para confirmar as escolhas feitas, além de buscar focalizar o projeto nas tarefas remanescentes. Este elemento junto com gerenciamento de projeto e liderança determina como o projeto converge ao final, com as necessidades de manufatura implantadas e a conseqüente introdução do produto ao mercado.

JOHNE; SNELSON (1988) ressalta os fatores de sucesso no NPD, incluindo como sub-atividades operacionais críticas aquelas relacionadas nesta dimensão, tais como os testes realizados na empresa, os testes realizados junto aos consumidores, os testes dos meios produtivos e os testes de mercado para comercialização.

\section{\ Revisões gerenciais e controle}

O papel da alta administração e a natureza de sua integração com o time de projeto constitui também um importante elemento. O caminho através do qual a alta administração revisa, avalia e modifica o projeto e suas metas, cria motivações e incentivos positivos e negativos durante o desenvolvimento do 
projeto. O tempo, a freqüência e o formato das revisões podem gerar um impacto significativo na eficácia e efetividade de todo o projeto.

Segundo ANTHONY; MCKAY (1992), as revisões gerenciais possibilitam à alta administração obter mais visibilidade do NPD, tendo a oportunidade de tomar decisões sem a necessidade do conhecimento de todos os detalhes do processo.

\section{\ Correções}

A incerteza associada ao NPD traz a necessidade de correções durante o processo. Esta dimensão trata de questões como medição e avaliação da situação do projeto, reprogramação e redefinição de tarefas, resolvendo diferenças entre o projeto e os requisitos do cliente e determinando quando a organização está pronta para o lançamento do produto. Talvez a parte mais importante desta dimensão seja o balanço entre a resolução de conflitos e sua adaptabilidade, a relação entre desafios inesperados e atrasos potenciais. Além disso, devem ser realizadas escolhas entre reprogramação de atividades para manter a motivação em contraposição para manter a credibilidade do projeto.

Segundo pesquisa realizada por ALLIPRANDINI; ROZENFELD; VALERI (2000), o processo de modificações de engenharia é definido como ECM (Engineering Change Management) e atende a qualquer modificação seja ela de desenho, de material, de custo, de dimensões geométricas ou mesmo de uma concepção totalmente nova. Existe um estímulo para que todos os problemas sejam resolvidos o mais cedo possível, onde a proposta de alteração passa por um comitê chamado CCB (Change Committee Board) formado pelos integrantes da gerência do projeto, no qual decide se a proposta é plausível ou não. Uma vez aprovada a proposta, ela é enviada de volta a pessoa que lançou e a todas as pessoas cuja atividade apresente interface com a parte a ser modificada. Deste modo, a modificação é realizada em conjunto, onde todo o processo é facilitado pela utilização da TI no fluxo de trabalho, utilizando-se de tais recursos que 
automaticamente executa os passos necessários para aprovações e compartilhamento de trabalho.

Estas seis dimensões são como os diversos componentes que formam um produto, ou seja, a organização deve ter um meio efetivo de definir produtos, deve entender os mecanismos e ferramentas para a resolução de problemas e deve entender e inserir estas questões ao controle e revisões da alta administração. Estas dimensões juntas devem criar um sistema coerente capaz de conduzir o processo ao seu objetivo final, que é o produto.

\subsection{O uso da TI no NPD}

A complexidade do sistema organizacional tem sido uma dificuldade pertinente, tanto nos estudos sobre organizações, com no estudo do desenvolvimento de produtos. Uma organização é um sistema formado por homens e máquinas com intensas, variadas e complexas relações entre si, tornando-se difícil à tarefa de compreendê-la. Portanto, através da análise do uso da TI neste complexo sistema se pode tirar informações úteis para as intervenções e gerenciamento das organizações. Para o estudo do processo do NPD, este complexo sistema dificulta a determinação do contorno que delimita a composição de tal processo, já que, na realidade, todos os elementos dos sistemas interagem entre si.

Diversos autores, dentre eles CUSUMANO; NOBEOKA (1992) e WHEELWRIGHT; CLARK (1992), afirmam que a inovação do produto é um contínuo e interfuncional processo de aprendizagem, tendo a transferência de conhecimentos e integração dentro e fora dos limites da empresa, onde a engenharia simultânea, o gerenciamento de projetos e a autonomia dos times de projeto desempenham um papel fundamental. O sucesso está cada vez mais no aumento da sinergia entre projetos considerando a aprendizagem e a transferência do conhecimento, utilizando-se a TI no NPD para a postergação deste aprendizado. 
Há, portanto diversas formas potenciais ou possíveis de transferência de conhecimento intra e interprojetos:

\ à partir dos recursos como as tecnologias de base computacional, onde o uso das ferramentas de CAD (Computer Aided Design), CAE (Computer Aided Engineering) e CAM (Computer Aided Manufacturing) melhoraram significativamente a eficiência do projeto do produto, do planejamento do processo e da implementação de seus resultados na produção. Têm-se ainda as ferramentas PDM (Product Data Management), DMU (Digital Mock-Up), CAPP (Computer Aided Process Planning), Prototipagem Rápida, etc.;

\ métodos e ferramentas de projeto: QFD (Quality Function Deployment), DFMEA (Design Failure Mode and Effects Analysis), PFMEA (Process Failure Mode and Effects Analysis), DFM/A (Design for Manufacturing / Assembly), etc.;

\ medidas de desempenho: benchmarking, auditoria pós-projeto, etc.;

u controle e planejamento do projeto: prazos e orçamentos, pontos de checagem e quality gates, etc.;

a políticas de gerenciamento dos recursos humanos: formação de times, treinamento, rotação de tarefas, etc.;

\ mecanismos de integração organizacional: gerentes de projetos, líderes de times, comitês, etc.;

口 definição de processos: seqüência de atividades e fases, ligações entre fases, etc.;

• estratégia da família de produtos: grau de inovação do produto, definição de padrões do produto, formação de parcerias e alianças, etc.

Estas formas de transferência de conhecimentos ocorrerão efetivamente com o uso da TI se não forem tratadas isoladamente, mas sim de forma integrada, envolvidas com a visão ampla do processo do NPD. 
Explanando em mais detalhes, a tecnologia DMU permite que todas as informações e funções relativas a um determinado produto possam ser apresentadas como um modelo realístico de computador. Antigamente, os engenheiros necessitavam de madeira ou partes de metal para julgar e examinar as harmonias espaciais de sua construção. Uma das principais funções do DMU consiste em auxiliar cada projetista a examinar seu desenvolvimento, controlando, por exemplo, no que se refere à superposição de peças / interferência (figura 3.10), exatidão de superfície de contato ou a manutenção de distâncias mínimas. Nos dias de hoje, pode-se determinar a melhor instalação possível dos componentes utilizando os dados de projeto em uma fase preliminar, onde modelos de simulação unidos aos a ferramenta do DMU representam uma função crucial para a engenharia simultânea inteiramente funcional. Porém vale salientar que, sua aplicação é limitada à disponibilidade dos recursos necessários e, principalmente ao tipo de análise a ser efetuada, onde o estudo preliminar virtual é mais uma forma de reduzir o prazo e o custo no NPD, podendo até eliminar a necessidade de um protótipo físico, porém em outros casos, fornece informações adicionais para que o primeiro protótipo físico apresente resultados mais próximos da configuração final do produto.

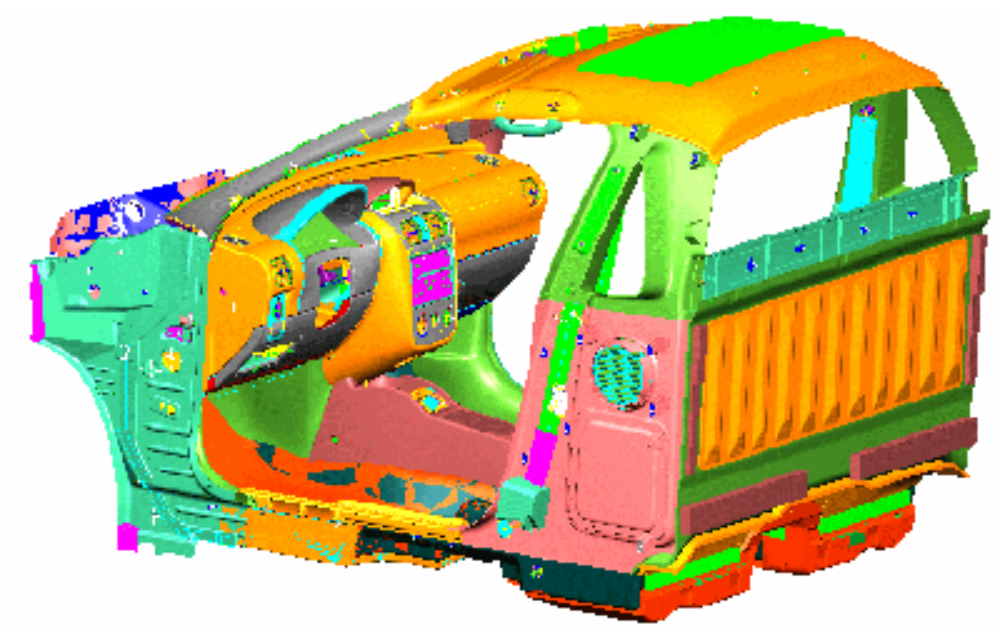

Figura 3.10 - Análise de interferências pelo DMU

Talvez a contribuição mais importante da TI para processo do NPD é o uso de bancos de dados combinado com a implementação da INTRANET. Ambos podem ser ferramentas poderosas em ordem para uma melhor aproximação de engenharia 
simultânea. O banco de dados provê métodos para armazenamento e recuperação de dados gerados pelo processo do NPD, como a estrutura do produto e documentos do projeto. A INTRANET habilita o processo e administração de workflow, provendo um melhor gerenciamento das informações e do processo do NPD. Esta idéia pode ser estendida ao uso da INTERNET, conectando empresas com seus clientes e fornecedores e outros importantes parceiros no processo do NPD (CHU; FAN, 1999 apud LAURINDO; CARVALHO, 2002).

Dentro deste cenário, a INTERNET aparece como uma aplicação de TI mais visível, já que fornece a infraestrutura sobre a qual são desenvolvidas as aplicações estratégicas de TI, onde se destacam o e-business e o e-commerce (EVANS; WUSTER, 1997 e FRONTINI, 1999 apud LAURINDO, 2001).

Na visão de PORTER (2001), a INTERNET por si raramente será uma vantagem competitiva, sendo que muitas empresas terão sucesso utilizando a INTERNET como um complemento dentro dos modos tradicionais de se competir, onde empresas estabelecidas em melhores posições, utilizam-se desta ferramenta para sustentarem suas vantagens existentes. 


\section{ASPECTOS METODOLÓGICOS}

Neste trabalho, adotam-se como aspectos metodológicos à abordagem da pesquisa qualitativa, bem como o conceito do método do estudo de caso, procurando relatar brevemente suas definições, características como também críticas quanto à aplicação de seus respectivos usos.

De uma forma geral, a maior parte dos trabalhos realizados relativos ao assunto sobre TI utilizaram à abordagem qualitativa com método de pesquisa, enquanto que os estudos empíricos representam 68\% dos trabalhos pesquisados, sendo que deste total, 21\% são estudos de caso (CLAVER; GONZÁLEZ; LLOPIS, 2000).

\subsection{A "Pesquisa Qualitativa"}

De acordo com o modelo do processo de pesquisa de BRYMAN (1990) apud LAURINDO (2000), há duas abordagens para a pesquisa organizacional: quantitativa e qualitativa. A pesquisa quantitativa é impulsionada por considerações prévias, já a pesquisa qualitativa busca o que é importante para aqueles que atuam no universo pesquisado, possibilitando uma melhor compreensão da organização e eventuais adaptações ao longo do estudo.

Enquanto estudos quantitativos geralmente procuram seguir com rigor um plano previamente estabelecido, a pesquisa qualitativa costuma ser direcionada ao longo de seu desenvolvimento, não buscando enumerar ou medir eventos e, geralmente, não empregando instrumental estatístico para análise dos dados. Dela faz parte a obtenção de dados descritivos mediante contato direto do observador com a situação objeto de estudo.

A pesquisa qualitativa revela áreas de consenso, tanto positivo quanto negativo nos padrões de respostas, no qual também determina quais idéias geram uma forte reação emocional. Além disso, é especialmente útil em situações que envolvem o desenvolvimento e aperfeiçoamento de novas idéias, sendo 
particularmente útil como ferramenta para determinar o que é importante para os clientes e porque é importante. Esse tipo de pesquisa fornece um processo a partir do qual questões-essenciais são identificadas e perguntas são formuladas, descobrindo o que importa para os clientes e por que.

\subsubsection{Características da pesquisa qualitativa}

Os estudos de pesquisa qualitativa diferem entre si quanto ao método, à forma e aos objetivos. GODOY (1995) ressalta a diversidade existente entre os trabalhos qualitativos e enumera um conjunto de características essenciais capazes de identificar uma pesquisa desse tipo, conforme a seguir:

a o ambiente natural como fonte direta de dados e o pesquisador como instrumento fundamental;

๑ o caráter descritivo;

• o significado que as pessoas dão às coisas e à sua vida como preocupação do pesquisador;

๑ enfoque indutivo.

Segundo MANNING (1979), o desenvolvimento de um estudo de pesquisa qualitativa supõe um corte temporal-espacial de determinado fenômeno por parte do pesquisador, sendo que esse corte define o campo e a dimensão em que o trabalho desenvolver-se-á, tendo um caráter fundamental em um estudo qualitativo, pois é por meio do território mapeado que os dados são coletados.

Em certa medida, os métodos qualitativos se assemelham a procedimentos de interpretação dos fenômenos que se emprega no nosso dia-a-dia, que têm a mesma natureza dos dados que o pesquisador qualitativo emprega em sua pesquisa. Tanto em um como em outro caso, trata-se de dados simbólicos, situados em determinado contexto, revelando parte da realidade ao mesmo tempo em que escondem outra parte. MAANEN (1979) comenta que, para não atravessar uma rua, basta que se veja aproximar um caminhão, onde não é necessário saber seu peso exato, a sua 
velocidade, de onde vem, etc. Nessa situação, o caminhão pode ser entendido como um símbolo de velocidade e força e, para tal finalidade de atravessar a rua, outras informações seriam irrelevantes. Há problemas e situações cuja análise pode ser feita sem quantificação de certos detalhes como: delimitação precisa do tempo em que ocorrem, lugares, causas, procedência dos agentes, etc., onde tais detalhes, embora obteníveis, seriam de pouca utilidade.

\subsubsection{Comparação entre pesquisa qualitativa e quantitativa}

As pesquisas qualitativa e quantitativa não se excluem, embora difiram quanto à forma e à ênfase, trazem como contribuição ao trabalho de pesquisa uma mistura de procedimentos de cunho racional e intuitivo capazes de contribuir para a melhor compreensão dos fenômenos. Pode-se distinguir o enfoque qualitativo do quantitativo, mas não seria correto afirmar que guardam relação de oposição.

Normalmente a pesquisa quantitativa se mostra apropriada quando existe a possibilidade de medidas quantificáveis de variáveis e interferências a partir de amostras, sendo que esse tipo de pesquisa utiliza medidas numéricas para testar e até comprovar hipóteses ou buscar padrões numéricos relacionados a conceitos cotidianos. Em contrapartida, a pesquisa qualitativa se caracteriza, principalmente pela ausência de medidas numéricas e análises estatísticas, examinando aspectos mais profundos e subjetivos do tema em estudo.

De uma forma geral, ETHOS INSTITUTO DE PESQUISA (2004) resumiu as diferenças entre pesquisa qualitativa e quantitativa na tabela 4.1. 
Tabela 4.1 - Diferenças entre pesquisa qualitativa e quantitativa - Adaptado de ETHOS INSTITUTO DE PESQUISA (2004)

\begin{tabular}{|c|c|}
\hline Quantitativa & Qualitativa \\
\hline Objetivo & Subjetivo \\
\hline Hard Science & Soft Science \\
\hline Testa a Teoria & Desenvolve a Teoria \\
\hline Redução, controle, precisão & $\begin{array}{l}\text { Descoberta, descrição, compreensão, } \\
\text { interpretação partilhada }\end{array}$ \\
\hline Mecanicista: partes são iguais ao todo & Organicista: o todo é mais do que as partes \\
\hline Possibilita análises estatísticas & $\begin{array}{l}\text { Possibilita narrativa rica, interpretações } \\
\text { individuais }\end{array}$ \\
\hline $\begin{array}{l}\text { Os elementos básicos da análise são } \\
\text { os números }\end{array}$ & $\begin{array}{c}\text { Os elementos básicos da análise são } \\
\text { palavras e idéias }\end{array}$ \\
\hline $\begin{array}{l}\text { O pesquisador mantém distância do } \\
\text { processo }\end{array}$ & O pesquisador participa do processo \\
\hline Independe do contexto & Depende do contexto \\
\hline Teste de hipóteses & Gera idéias e questões para pesquisa \\
\hline O raciocínio é lógico e dedutivo & O raciocínio é dialético e indutivo \\
\hline Estabelecem relações, causas & Descreve os significados, descobertas \\
\hline Busca generalizações & Busca particularidades \\
\hline Preocupa-se com as quantidades & $\begin{array}{l}\text { Preocupa-se com a qualidade das } \\
\text { informações e respostas }\end{array}$ \\
\hline Utiliza instrumentos especifícos & Utiliza a comunicação e observação \\
\hline
\end{tabular}

Em face ao exposto, para o desenvolvimento do presente trabalho, no qual é necessária a compreensão da extensão e das formas de impacto do uso da TI no NPD em indústrias automotivas, a abordagem “qualitativa” torna-se a mais adequada ao estudo da estratégia e organização da TI. 


\subsection{O método do "Estudo de Caso"}

O estudo de caso consiste em uma investigação detalhada de uma ou mais organizações ou grupos dentro de uma organização com vistas a prover uma análise do contexto e dos processos envolvidos no fenômeno em estudo. O fenômeno não está isolado de seu contexto (como nas pesquisas de laboratório), já que o interesse do pesquisador é justamente essa relação entre o fenômeno e seu contexto. A abordagem de estudo de caso não é um método propriamente dito, mas uma estratégia de pesquisa (HARTLEY, 1994).

Ao comparar o método do estudo de caso com outros métodos, YIN (1994) afirma que, para se definir o método a ser utilizado é preciso analisar as questões que são colocadas pela investigação. De modo específico, este método é adequado para responder às questões “como” e "porque” que são questões explicativas e tratam de relações operacionais que ocorrem ao longo do tempo mais do que freqüências ou incidências.

HARTLEY (1994) destaca que, dentro da ampla estratégia de pesquisa do estudo de caso, se pode empregar vários métodos - qualitativos, quantitativos ou ambos - embora a ênfase seja empregar métodos qualitativos, em função dos tipos de problemas que geralmente são associados e melhor compreendidos por meio de estudos de caso. O estudo de caso se caracteriza pela capacidade de lidar com uma completa variedade de evidências tais como: documentos, registros de arquivos, artefatos físicos, observação direta, observação participante, entrevistas (semiestruturadas ou não estruturadas), sendo que cada uma destas evidências requer habilidades específicas e procedimentos metodológicos específicos.

O método do estudo de caso, como todos os métodos de pesquisa, é mais apropriado para algumas situações do que para outras. Ao se decidir pelo uso deste método de pesquisa, o pesquisador deve ter em mente as críticas e dúvidas que são normalmente abordadas ao método em questão, devendo tomar as precauções e cuidados necessários para evitá-los ou minimizar as suas conseqüências. 
Pode-se ainda encontrar em CLAVER; GONZÁLEZ; LLOPIS (2000) que o método do estudo de caso têm sido extensivamente utilizado nas pesquisas em TI, ajustando-se pelas seguintes razões:

\ O pesquisador pode estudar a TI no seu “ambiente natural”, aprender o “estado da arte” e desenvolver teorias derivadas da prática;

- O estudo de caso possibilita ao pesquisador responder as perguntas “como” e "porque" de forma a compreender a natureza e a complexidade dos processos envolvidos;

\ O método do estudo de caso permite que se desenvolvam pesquisas onde há poucos estudos prévios, o que é adequado a área de TI, na qual novos temas surgem a todo momento, sendo o estudo de caso muitas vezes o ponto de partida do estudo sobre tais temas.

\subsubsection{Características do método do estudo de caso}

De forma geral, BENBASAT; GOLDSTEIN; MEAD (1987) lista onze características fundamentais do método do estudo de caso que são demonstradas a seguir:

\ Fenômeno observado em seu ambiente natural;

\ Dados coletados por diversos meios;

- A complexidade da unidade é estudada intensamente;

- Estudos de caso mais satisfatórios para as etapas de exploração, classificação e desenvolvimento de hipóteses do processo de construção do conhecimento;

【 Nenhum controle experimental ou manipulação é envolvido;

- O pesquisador não precisa especificar previamente o conjunto de variáveis dependentes e independentes;

口 Os resultados obtidos dependem muito do poder de integração do pesquisador;

- Podem ocorrer mudanças na seleção do caso ou dos métodos de coleta de dados à medida que pesquisador desenvolve novas hipóteses; 
• Estudo de caso é útil no estudo das perguntas "como" e "porque", ao invés de freqüências ou incidências;

• O foco está em eventos contemporâneos.

Conforme mencionado por HARTLEY (1994), o ponto forte do estudo de caso é sua capacidade de explorar processos sociais à medida que esses ocorrem nas organizações, permitindo uma análise processual, contextual e longitudinal das ações e significados que ocorrem e são construídos nas organizações. A natureza mais aberta da coleta de dados em estudos de caso permite analisar em profundidade os processo e as relações entre eles.

\subsubsection{Críticas em relação ao método do estudo de caso}

Apesar de ser uma forma distinta para a inquirição empírica, o estudo de caso é visto, por alguns pesquisadores, como uma forma menos desejável do que a experimentação ou surveys. Segundo YIN (1994), isto ocorre por razões como a grande preocupação sobre a falta de rigor das pesquisas, onde o pesquisador do estudo de caso tem sido descuidado e tem admitido evidências equivocadas ou enviesadas para influenciar a direção das descobertas e das conclusões.

Na visão de HARTLEY (1994), um método por si só não é bom ou ruim. O julgamento a respeito de um método em uma determinada pesquisa depende de dois fatores: o relacionamento entre a teoria e o método; e como o pesquisador lida com as potenciais deficiências do método.

Um outro aspecto levantado por GOODE; HATT (1967) apud BRESSAN (2000), é que o pesquisador chega a ter a sensação de certeza sobre as suas próprias conclusões, onde cada caso desenvolvido assume dimensões completas na mente do pesquisador, passando a sentir-se seguro de poder responder um maior número de questões do que poderia fazer somente com os dados registrados, resultando, naturalmente, em uma grande tentação de extrapolar sem garantia. 
Ainda se encontra em YIN (1994) a preocupação em relação ao método do estudo de caso que fornece pequena base para generalizações científicas uma vez que, por estudar um ou alguns casos não se constitui em amostra da população, tornando-se sem significado qualquer tentativa de generalização para populações.

Embora haja diversas críticas com relação ao método do estudo de caso, pesquisando a bibliografia existente é possível aprofundar-se no assunto, no qual é possível encontrar algumas medidas preventivas que podem ser utilizadas no sentido de contornar tais problemas e obter um bom resultado no método citado.

\subsection{Proposições do trabalho}

Conforme mencionado anteriormente, o método escolhido para o desenvolvimento deste trabalho foi o Estudo de Caso, que apesar de suas limitações, em termos de potencialidade e possibilidades de generalizações, permite, através de uma análise mais qualitativa, identificar os benefícios da utilização a TI no processo do NPD, compreendendo melhor os fatores primordiais: tempo, qualidade e custo.

As informações necessárias para a realização do estudo de caso, bem como da sua respectiva análise foram coletadas pela autora "in loco" na empresa estudada, no qual ela também é funcionária. Contudo, na pesquisa a atuação foi como observadora e não como agente, utilizando informações complementares como apresentações oficiais da empresa em congressos e seminários, além de informações públicas divulgadas em seus sites na INTERNET.

Mediante ao exposto e partindo do referencial teórico mencionado nos capítulos 2 e 3, elaboraram-se as seguintes proposições:

1. A TI é um importante recurso para o NPD, no qual esta tem basicamente a função de armazenamento eficaz das informações através de bancos de dados. 
2. Cada vez mais a aplicação da TI sob a forma de ferramentas como CAD/CAE/CAM no processo do NPD tem-se demonstrado estrategicamente vital para as indústrias automobilísticas.

3. A TI pode gerar impacto estratégico mesmo em indústrias mais tradicionais, como o setor de manufatura. 


\section{ESTUDO DE CASO}

O estudo de caso foi conduzido no ambiente da General Motors do Brasil, no qual forneceu subsídios necessários para a análise da utilização da TI no NPD em projetos automotivos, porém com algumas ressalvas por uma questão de confidencialidade recomendada pela empresa, não afetando o objetivo deste trabalho.

A General Motors é considerada a maior companhia fabricante de automóveis do mundo, onde este grandioso título de número 1 se deve, principalmente, ao fato do grupo GM ser formado por diversas marcas e alianças em todas as regiões do globo. A corporação GM engloba mais de 10 marcas (figura 5.1), destacando-se: Chevrolet, GMC, Opel, Vauxhall, Cadillac, Saturn, Oldsmobile, e em termos de alianças estratégicas, se destacam: Fiat, Subaru, Saab, Daewoo, Isuzu, etc. Para continuar sendo a maior empresa automobilística do mundo nos próximos anos, a GM está alicerçada em 5 valores vitais que a compõem: seus veículos, empregados, fornecedores, concessionários e clientes, e no qual segundo PORTER (1979), é uma forma de se manter uma estratégia diferenciada. 


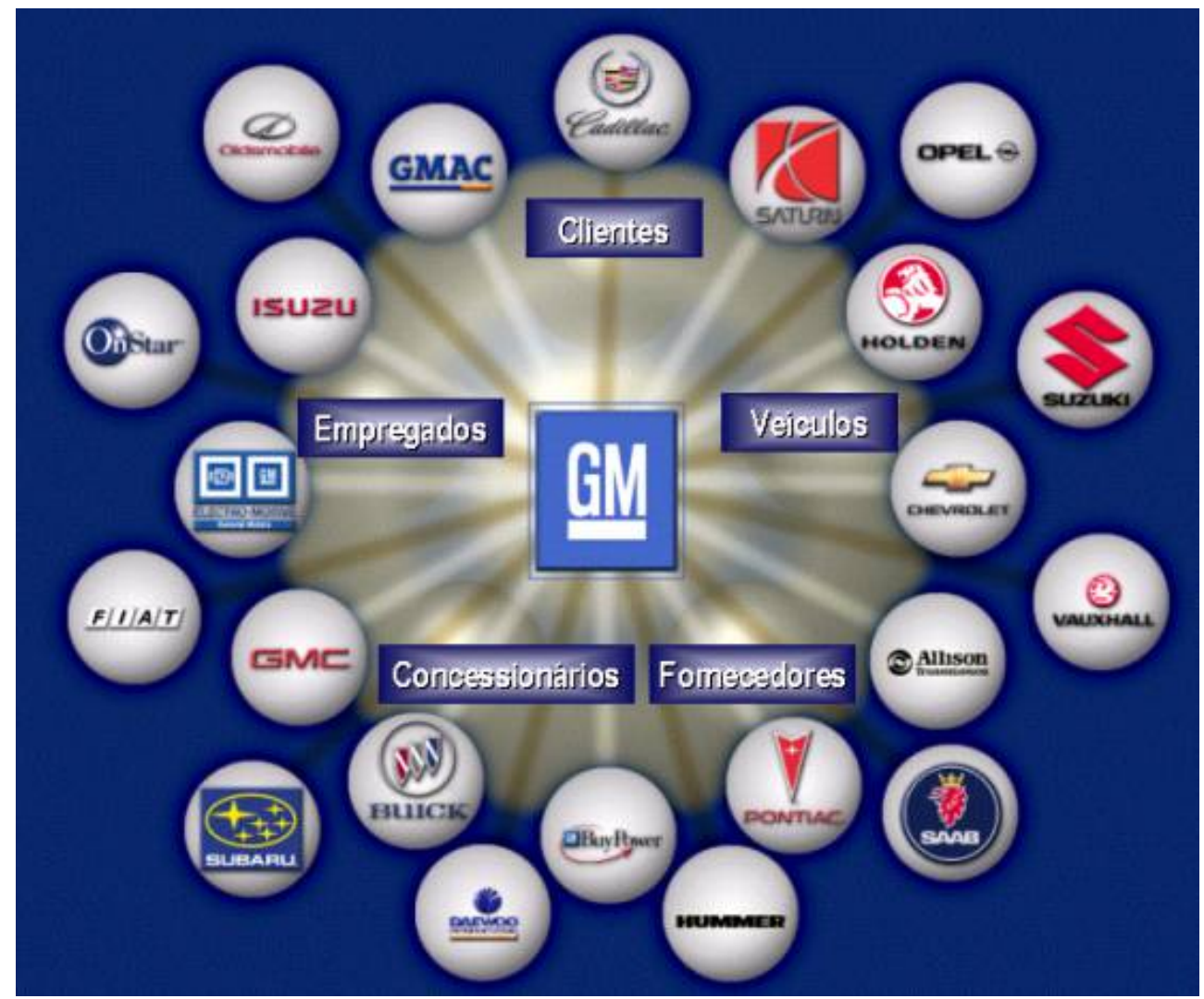

Figura 5.1 - Marcas e alianças da GM

No Brasil, a General Motors está completando 80 anos de história possuindo 19.000 empregados nos dias de hoje, ocupando basicamente quatro grandes complexos industriais, sendo o primeiro localizado em São Caetano do Sul - SP (área de 600.000 metros quadrados), o segundo em São José dos Campos - SP (área de 2.700.000 metros quadrados), o terceiro em Mogi das Cruzes - SP (área de 80.000 metros quadrados) e o quarto complexo industrial e o mais moderno localizado em Gravataí - RS (área de 380.000 metros quadrados). Vale acrescentar que, existem outras áreas de suporte às operações principais de produção e comercialização de seus veículos, como, o Campo de Provas de Cruz Alta em Indaiatuba - SP e o Centro de Distribuição em Sorocaba - SP.

A GMB possui aproximadamente 1.240 engenheiros de produto e manufatura em um contexto total com mais de 42.000 pessoas ao redor do mundo em 16 centros 
de desenvolvimento de produtos e processos de produção (figura 5.2), acessando dados matemáticos dos veículos da GM Corporation.

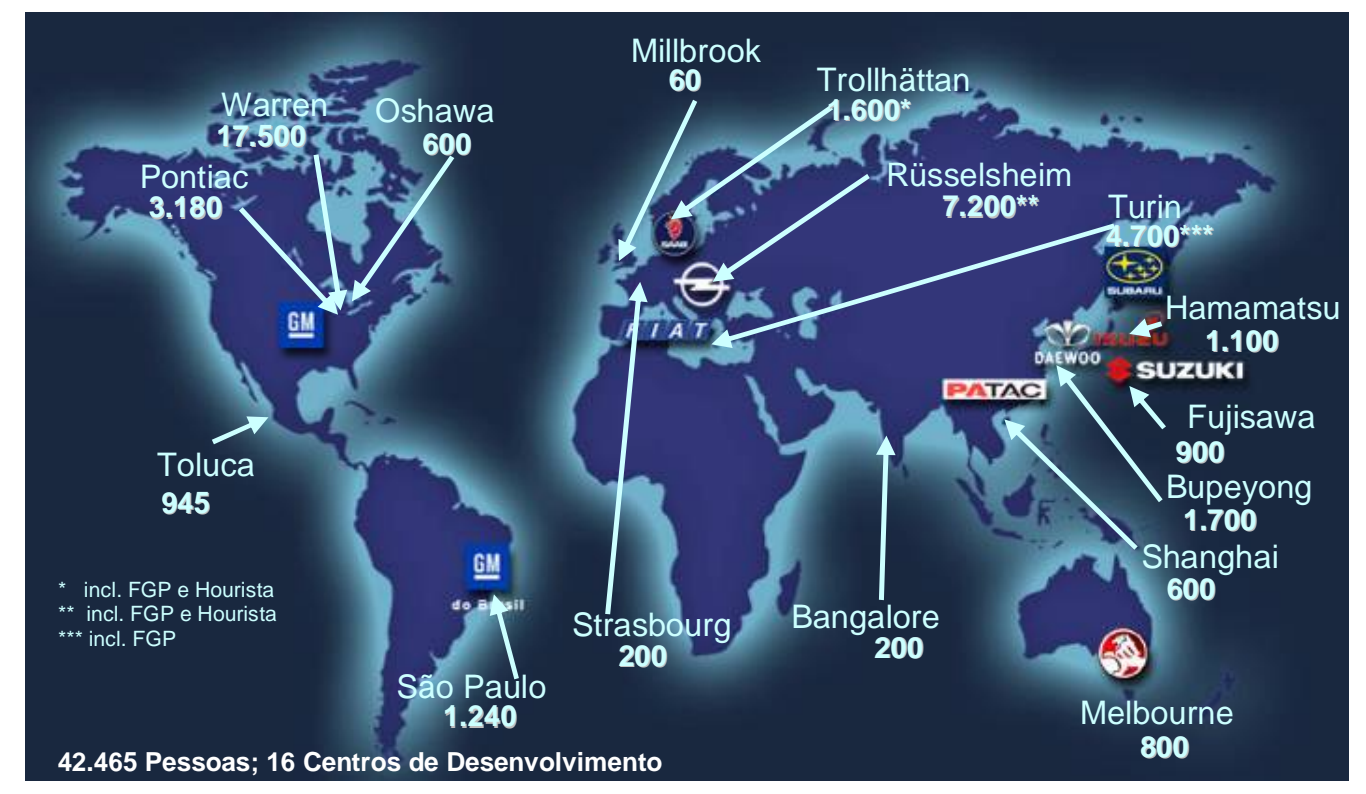

Figura 5.2 - Centros de desenvolvimento da GM

\subsection{Otimização do parâmetro “Tempo"}

Neste contexto, para manter a liderança almejada, diversos fatores foram analisados e desenvolvidos, sendo a aplicação da TI uma estratégia fundamental na otimização de tempo no desenvolvimento de veículos. Para tal a GM possui um processo de NPD próprio, chamado de GVDP (Global Vehicle Development Process), no qual teve seu início no começo dos anos 90, como um instrumento de integração capaz de controlar as atividades de pesquisa, planejamento, criação, desenvolvimento, manufatura, lançamento, comercialização, distribuição e assistência técnica dos produtos GM, especificando funções e datas dentro do processo de planejamento e desenvolvimento de um projeto. Naquela época, o GVDP médio para o desenvolvimento de um projeto novo era de aproximadamente 60 meses. Ao longo dos anos este processo foi evoluindo e em 1996, o GVDP aplicado para os programas tinha uma média de 48 meses. Porém, ainda eram caracterizados por possuir uma integração mínima, ou seja: 
口 Múltiplos sistemas de projeto em uso;

口 Múltiplos processos de projeto;

口 Múltiplos processos de Engenharia de Manufatura;

๑ Implementação não-padronizada de processos.

De uma forma geral, denotava-se a pouca utilização do conceito de Engenharia Global. Como estratégia de se alterar este panorama, se estabeleceu um caminho duplo de atividades, tendo em uma das vertentes, os "Processos", e na outra vertente, a “Infraestrutura”. Em relação aos “Processos”, a idealização foi de criá-los cada vez mais enxutos, através da alteração do GVDP e da reavaliação e comunização dos demais processos. Com relação à “Infraestrutura”, foi atualizada de acordo com o desenvolvimento de novas aplicações, construindo uma via de dados matemáticos e promovendo uma integração de todas as áreas de desenvolvimento.

Como resultado, no desenvolvimento de um projeto na GM, todas as etapas, desde sua criação, projeto conceitual, projeto detalhado, simulações via CAE e o projeto de manufatura do veículo, estão sendo regidas por Aplicações Paramétricas Integradas (figura 5.3). As Aplicações Paramétricas Integradas são constituídas por um Núcleo de Modelagem Sólida, como o Unigraphics, por um Gerenciador de Dados Matemáticos e Processos, como o TcAE (Team center Automotive Edition) e, por último, por um Representador Comum para Visualização, como o VisMockup. Todos estes sistemas que compõem as Aplicações Paramétricas Integradas são representados por um banco de dados e por uma biblioteca de recursos reutilizáveis que proporcionam a realização de tarefas otimizadas dentro de um projeto, como: avaliação conceitual, revisão do projeto, simulação de fábrica, documentos de processo e serviços e comunicação interligada com áreas internas (Finanças, Compras), com outras divisões, bem como com fornecedores/ parceiros, permitindo o uso progressivo e vinculado dos dados matemáticos em todas as fases do GVDP. 


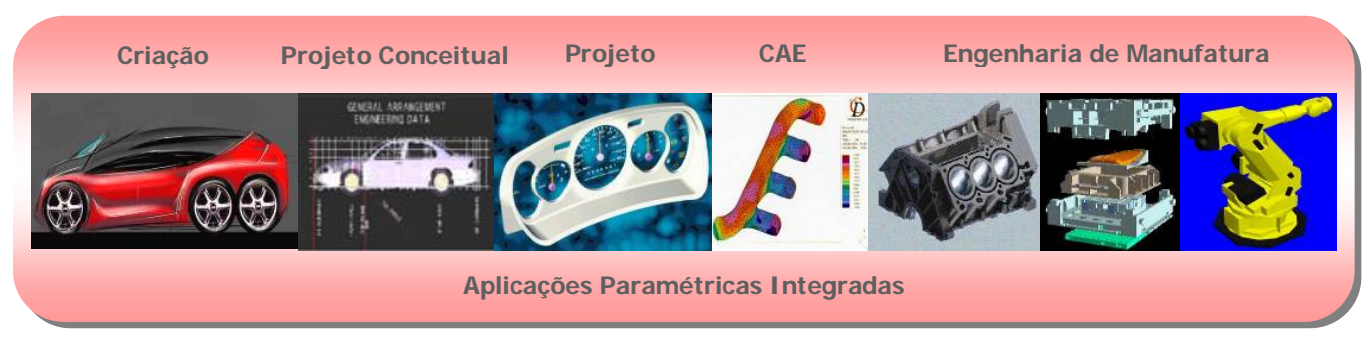

Figura 5.3 - Aplicações paramétricas integradas

Pode-se verificar também a utilização estratégica de ferramentas de análise globais e comuns de modo a suprir todas as necessidades de cada centro de desenvolvimento de produto da General Motors. Sendo assim, os sistemas de CAD/CAE/CAM existentes dentro da GM são comuns mundialmente em todos os centros de desenvolvimento. A GM possui atualmente 11.000 estações de trabalho Unigraphics, 18.000 computadores e estações com TcAE e 26.000 computadores e estações de trabalho como o VisMockup, com a finalidade de visualização.

É importante citar que o VisMockup é largamente utilizado na GM permitindo a visualização de dados a partir de qualquer computador que esteja conectado à rede de dados. A grande vantagem deste software está justamente no fato dele rodar em computadores de baixa configuração, não necessitando de um hardware pesado para tal, como é o caso das estações gráficas. Isto é possível porque este software trabalha somente com a porção dos contornos externos das imagens geradas a partir do CAD, removendo o modelo matemático que suporta a estrutura do sólido da imagem, o que torna o arquivo extremamente leve para se trabalhar.

Com isso, a redução do tempo total do processo foi notória. Com a aplicação da infraestrutura de TI, no ano de 2000 já foi possível se chegar a um tempo de desenvolvimento da ordem de 24 meses. Com a aplicação de um Programa de Integração de Sistemas, convergindo para um sistema de última geração para o desenvolvimento de produtos e a integração de framework, a partir de 2003 já é possível o desenvolvimento de um projeto em apenas 18 meses (figura 5.4). 


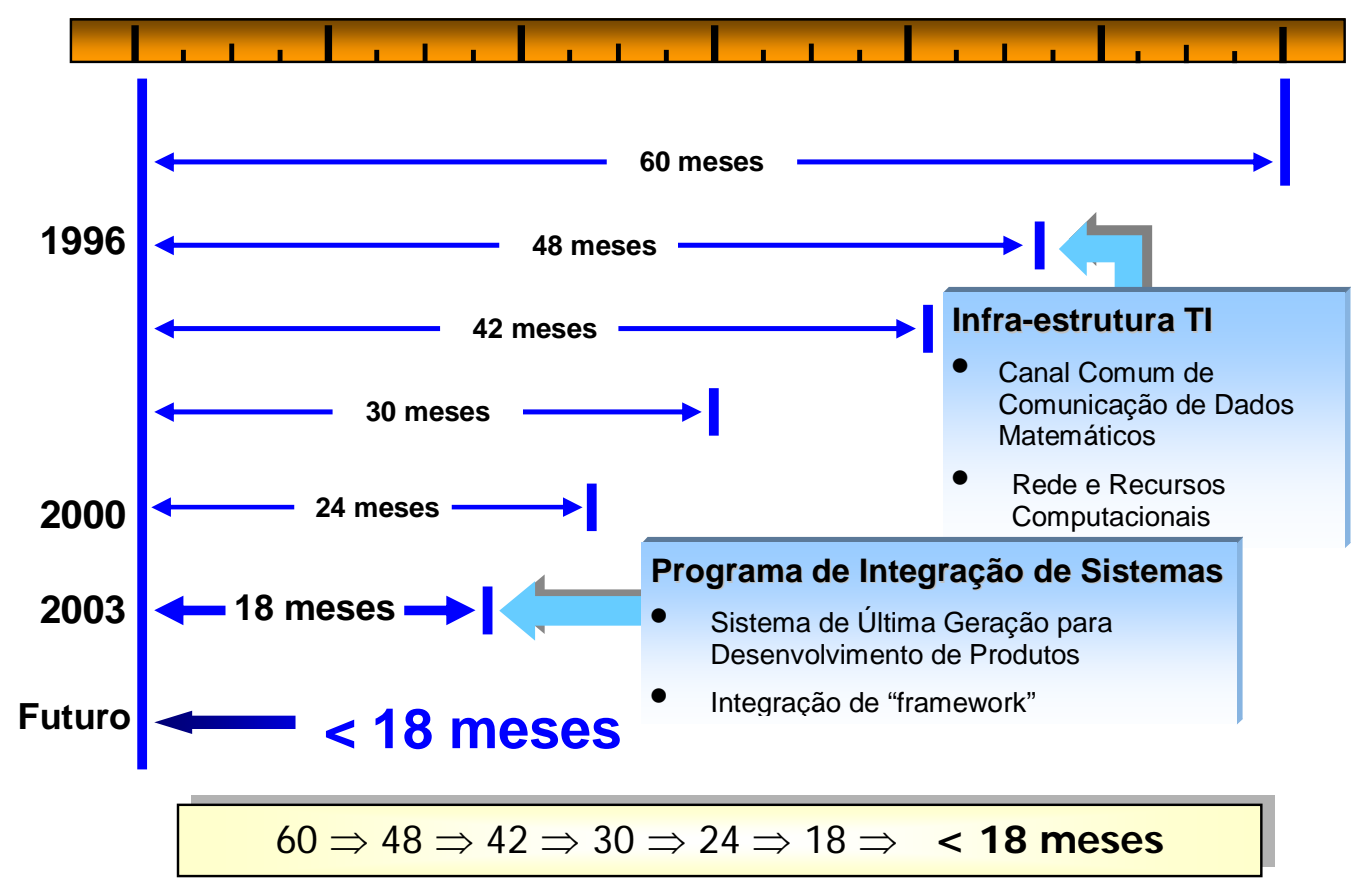

Figura 5.4 - Redução do tempo do GVDP na GM

Portanto, ao se analisar a redução do tempo de desenvolvimento com o passar dos anos, nota-se que a evolução foi determinante. Cada área/ fase integrante do GVDP, ou seja, Planning, Estilo, Engenharia do Produto, Engenharia de Manufatura, Engenharia Ferramental, instalações de chão de fábrica e início de produção necessitou passar por uma espécie de reengenharia para se adequar às novas características. Contudo o mais importante é que o objetivo foi alcançado, ou seja, estabeleceu-se um processo mais rápido com sistemas de engenharia globais, onde a Engenharia Simultânea foi consolidada, garantido a redução do tempo de desenvolvimento total do produto.

\subsection{Otimização do parâmetro "Custo" e "Qualidade”}

No tocante a redução de custo e melhoria da qualidade no desenvolvimento de um veículo, pode-se verificar uma acentuada evolução quanto à utilização da TI, onde o aperfeiçoamento quantitativo e qualitativo do uso de recursos de simulação e análise virtual aplicada ao produto, à manufatura e aos processos produtivos, vem se tornando uma constante no desenvolvimento do produto. 
Na área de Estilo na GMB, a inovação ficou por conta da utilização de modelos digitais a partir de esboços conceituais, gerando modelos em wire frame e “renderizados”, tornando-se possível à realização de simulações e avaliações iniciais do conceito do projeto em uma fase preliminar. O modelo em wire frame é utilizado como base para conceituação do projeto de ferramentas de estampagem e moldes de plástico (figura 5.5).

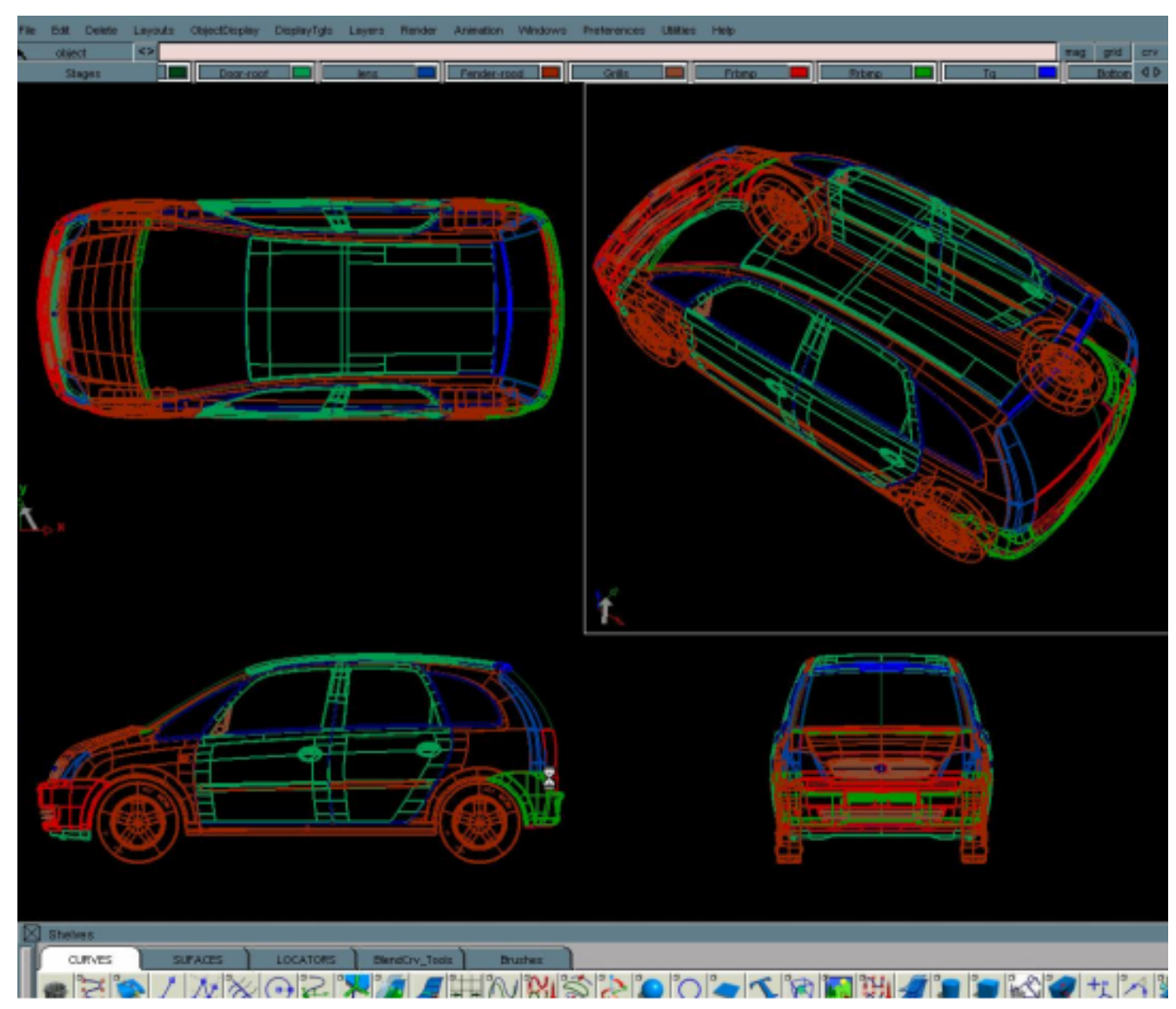

Figura 5.5 - Modelo em “wire frame”

Já o modelo "renderizado" tem como objetivo auxiliar no refino das superfícies definidoras das interfaces do veículo antes da construção do modelo “CLAY” (modelo físico escala 1:1 em argila), (figura 5.6). 


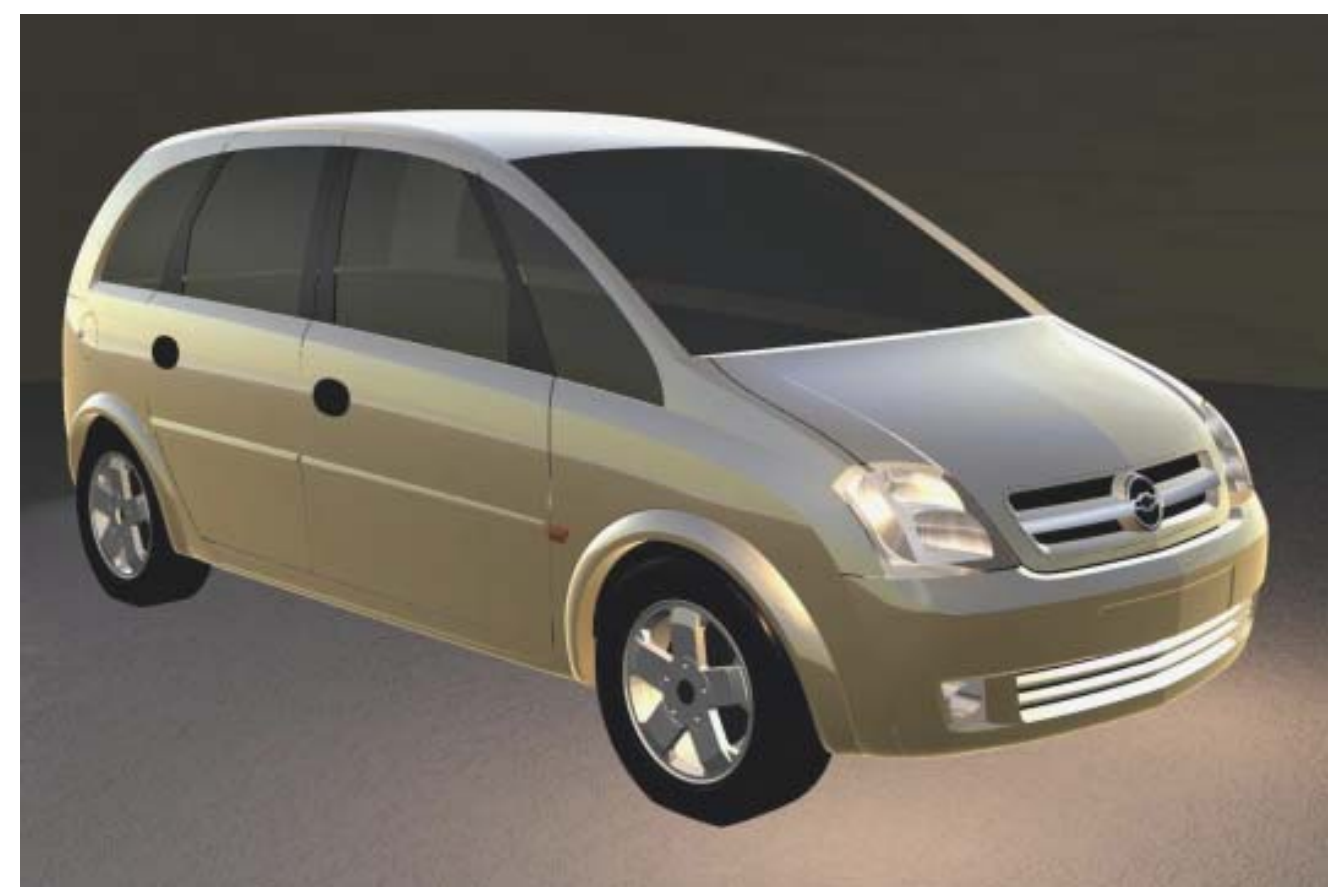

Figura 5.6 - Modelo “renderizado”

O uso da TI na GMB também propiciou a aplicação de algumas ferramentas até então não imaginadas de serem aplicadas ao processo, como é o caso da Realidade Virtual, onde se denota um considerável retorno em termos de qualidade e acima de tudo uma redução acentuada no custo de desenvolvimento. Dispondo-se de uma sala apropriada para exibição conforme figura 5.7, com equipamentos de projeção 3D interligados diretamente a uma estação gráfica, que por sua vez está ligada à rede da via de dados, é possível a visualização da peça, com o auxílio de óculos especiais, em 3 dimensões com total realismo, permitindo aos usuários análises mais detalhadas e concretas do veículo antes de se aplicar recursos na construção de modelos físicos. 


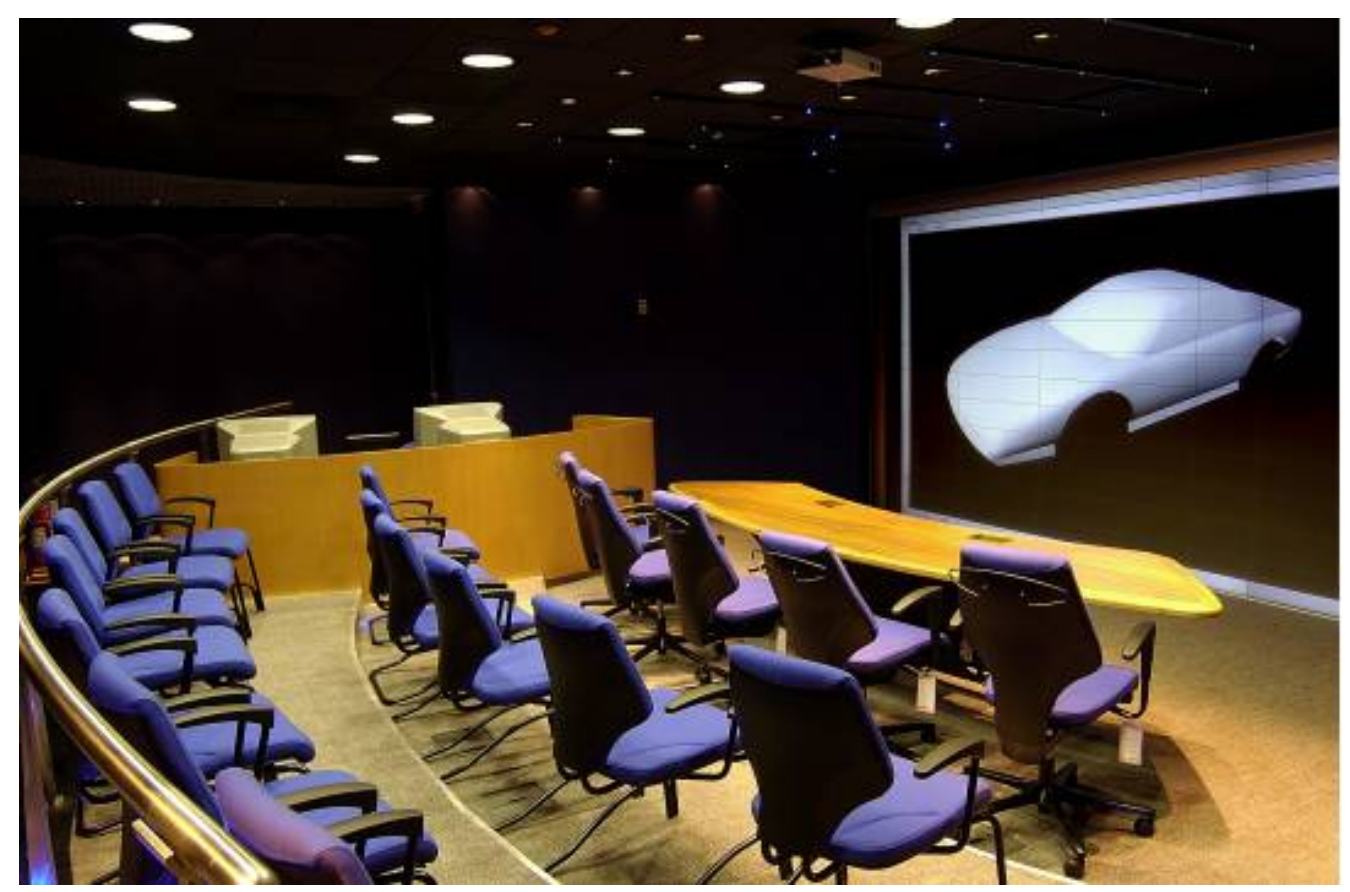

Figura 5.7 - Sala principal de realidade virtual na GMB

Atualmente, após os modelos virtuais e a determinação das superfícies do veículo, algumas fases de construção de protótipos e testes de validação foram substituídas pela aplicação de análises virtuais, representando uma grande economia para a GMB e, conseqüentemente para o consumidor, visto que um protótipo físico pode chegar a custar $\mathrm{R} \$ 1.000 .000,00$ dependendo do projeto e do estágio de desenvolvimento, não considerando o custo dos testes físicos e de todas as análises propriamente ditas. As análises virtuais são realizadas através de modelos matemáticos antes da confecção do primeiro protótipo, onde se pode destacar as seguintes análises virtuais realizadas na GMB:

- Durabilidade: esta análise permite a verificação de problemas muito antes dos testes físicos realizados no Campo de Provas, onde para isso a GMB conta com um programa desenvolvido internamente que simula as condições existentes no Campo de Provas da Cruz Alta, apresentado uma correlação eficaz com os testes reais. Isto propiciou uma redução considerável em termos de recursos e tempo, no qual um teste completo 
de durabilidade dura cerca de seis meses e o mesmo procedimento realizado virtualmente é realizado em 2 minutos (figura 5.8).

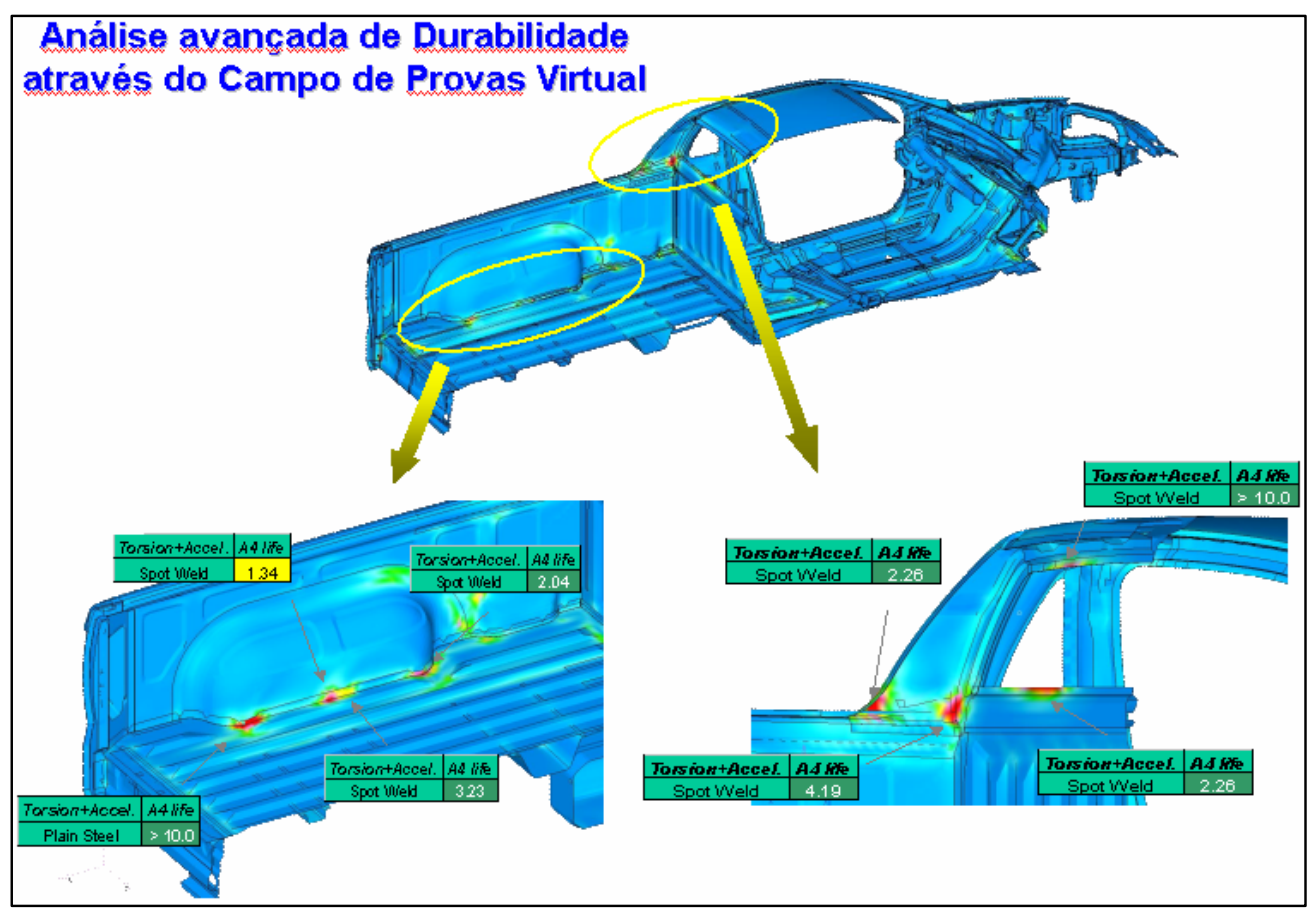

Figura 5.8 - Análise avançada de durabilidade

- Análise Estrutural: As análises executadas para o desenvolvimento da estrutura do veículo é outro exemplo realizado, onde aplicando diversos carregamentos pré-estabelecidos em uma região a ser analisada, avalia-se o desempenho estrutural do veículo a fim de garantir a qualidade na construção do protótipo físico, bem como do produto final (figura 5.9). 


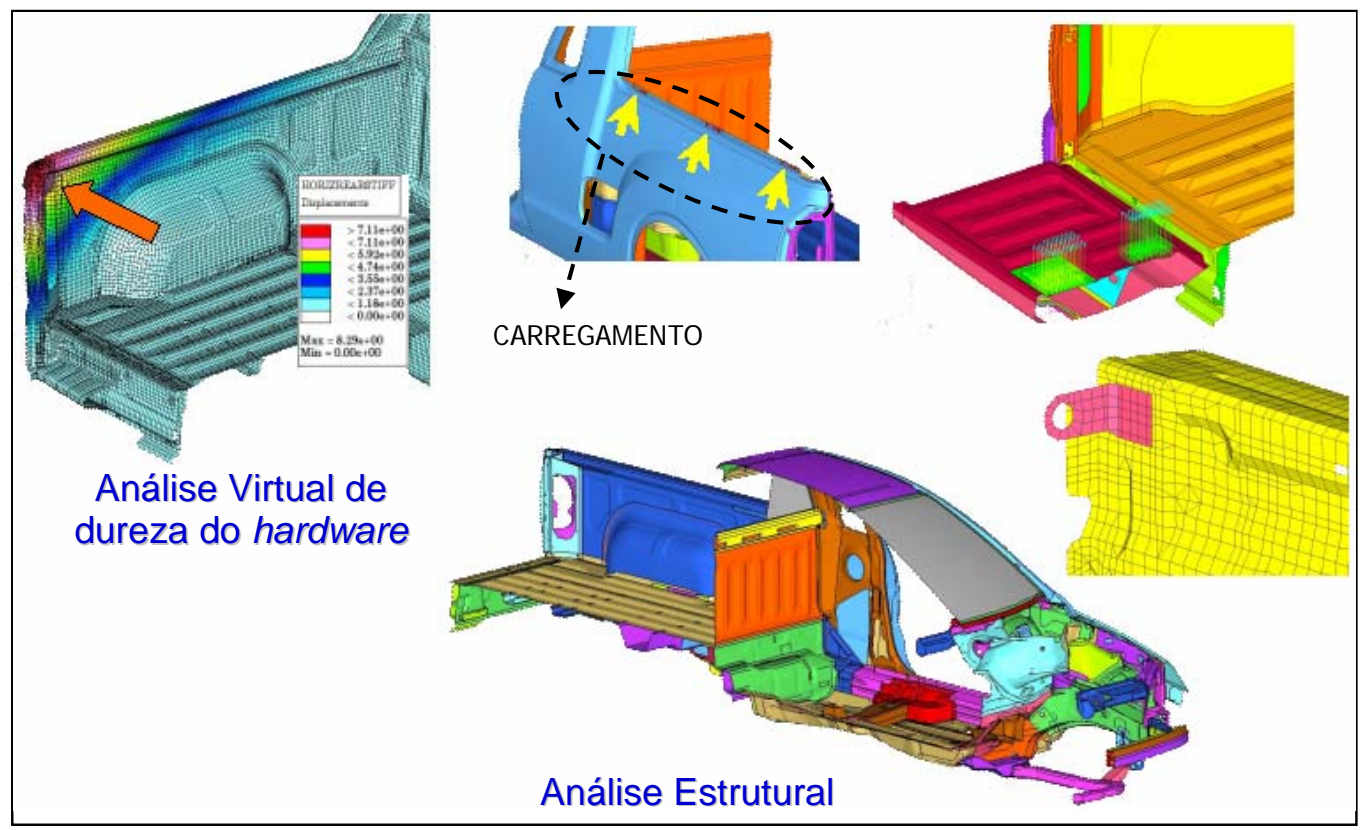

Figura 5.9 - Análise avançada estrutural

- Análise Térmica - Fluxo de Ar: Através da simulação do fluxo de ar induzido na região frontal é possível se verificar as condições térmicas para início do desenvolvimento do sistema de arrefecimento e ar condicionado do veículo, antes mesmo da confecção do primeiro protótipo (figura 5.10). 


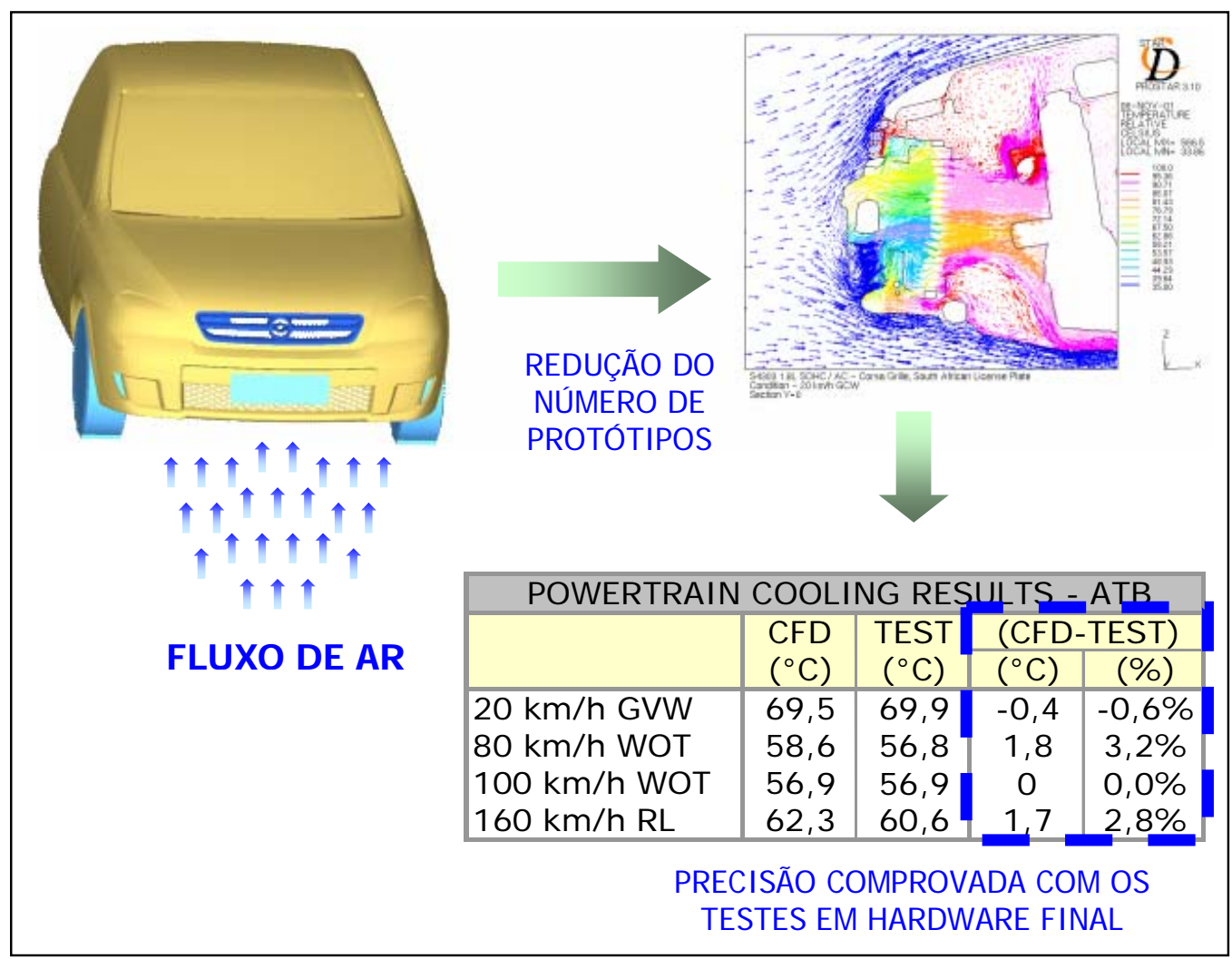

Figura 5.10 - Análise térmica - Fluxo de ar

- Teste de Impacto: A avaliação dos testes de impacto realizados virtualmente tornara-se mais rápidas e alicerçadas por correlação de dados matemáticos com teste reais, onde a GMB tem empregado cada vez mais esta ferramenta de modo a garantir a segurança dos ocupantes, o desempenho estrutural, o espaço de sobrevivência e as deformações plásticas, ou seja, a qualidade do veículo, considerando inclusive procedimentos mais severos exigidos somente na Europa (figura 5.11). Dentre os principais testes de impacto realizados na GMB tem-se: Teste de impacto frontal, lateral, frontal com barreira rígida e traseira, conforme se pode verificar na figura 5.12 . 


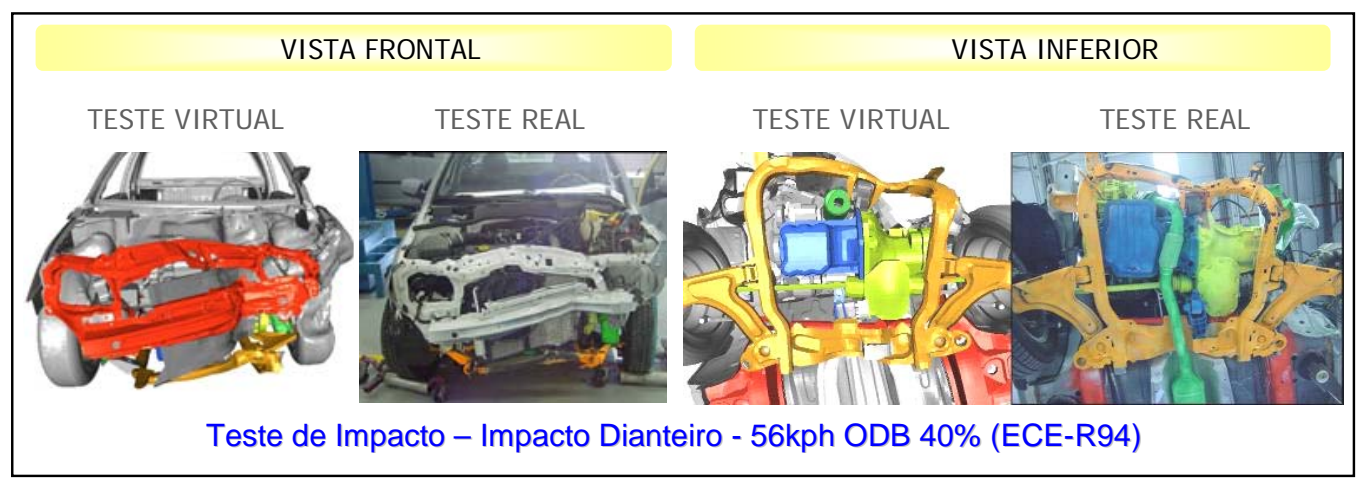

Figura 5.11 - Teste de impacto virtual e real

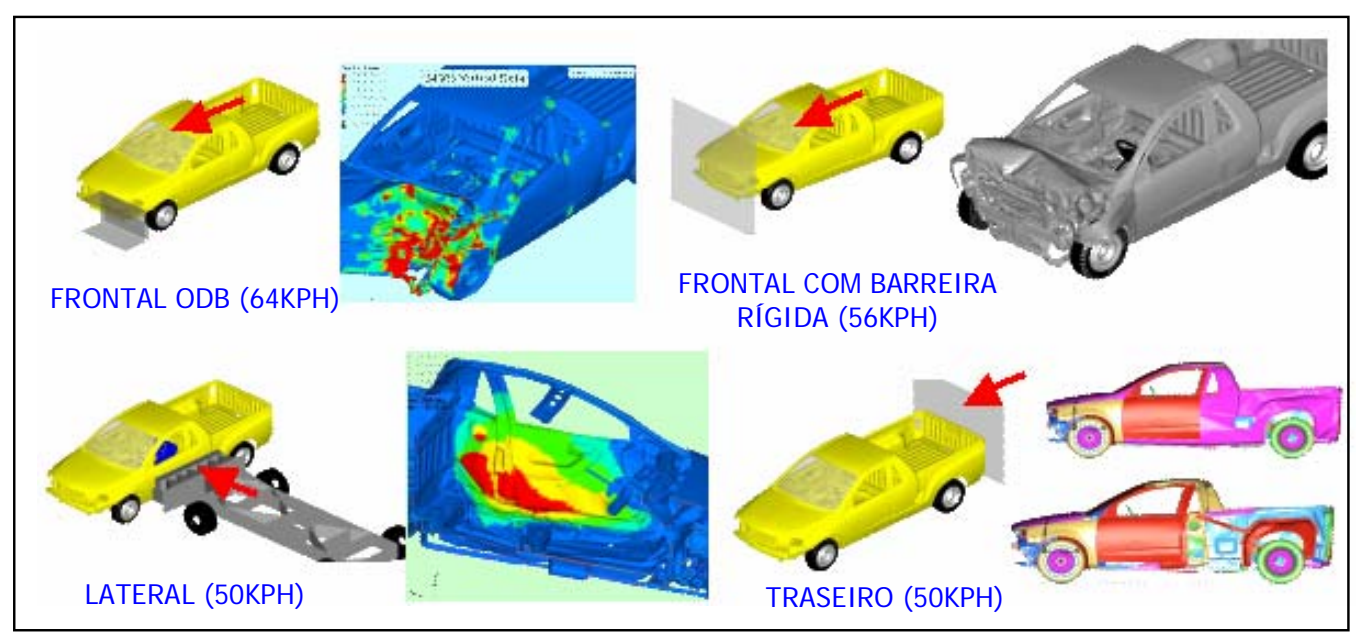

Figura 5.12 - Tipos de teste de impacto realizados na GMB

\ Digital Mock-Up: Considerada uma das principais vantagens no ambiente virtual no tocante à economia de tempo, a qualidade das informações e principalmente a redução de custo e risco, o DMU tem como objetivo verificar as montagens de conjuntos, a existência de interferências e/ou folgas, a quantidade de peças, os roteiros de tubulações e chicotes (figura 5.13), o alinhamento, a validação do modelo 3D antes da construção das peças físicas, dentre outros. 


\section{ROTEI RO DE CHI COTE}
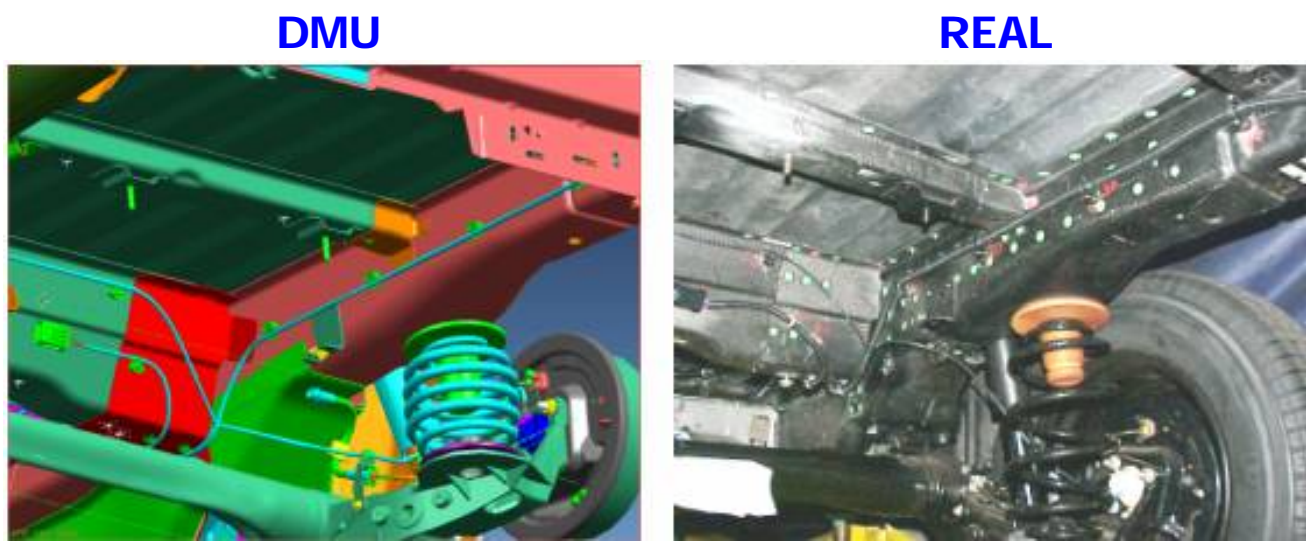

Figura 5.13 - Designação de roteiro para chicote utilizando o DMU

As análises de DMU não se restringem aos componentes do veículo e o acesso para serviços, mas também é muito utilizada pela Engenharia de Manufatura auxiliando no estudo de acesso de máquinas de solda e principais pontos de localização, provendo informações para o projeto de dispositivos de montagem, bem como avaliação de ergonomia, resultando em ajustes finais mínimos, redução de retrabalhos, especificação precisa de equipamentos e condições adequadas de trabalho ao operador (figura 5.14).

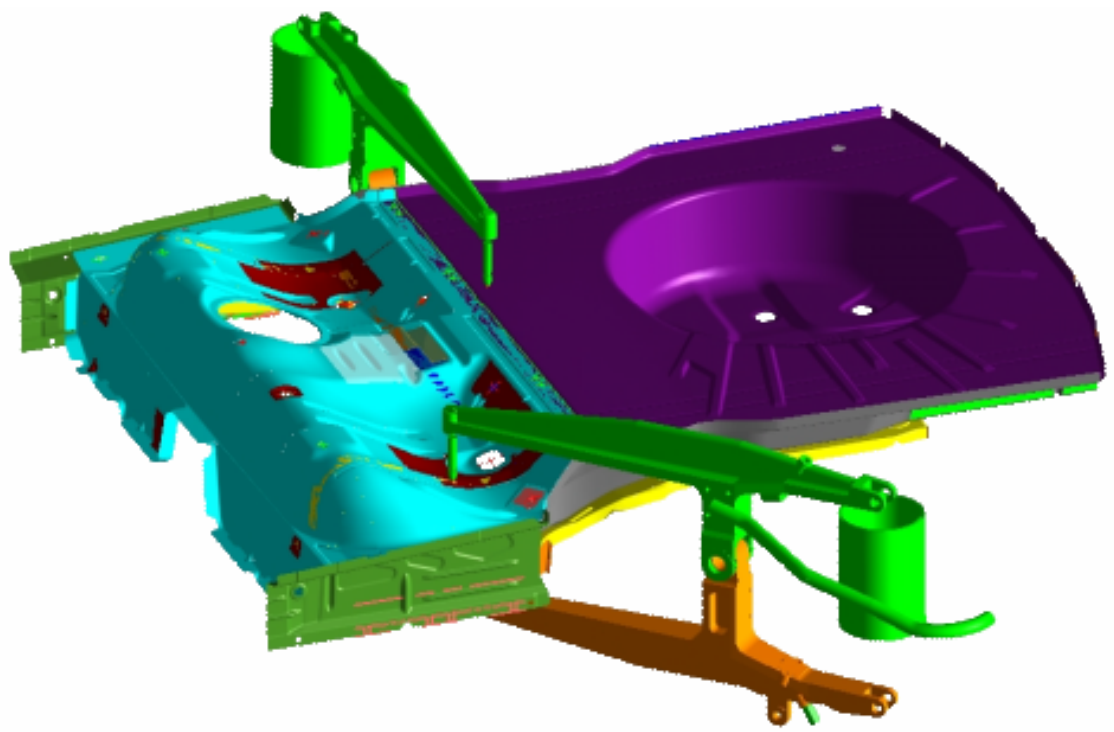

Figura 5.14 - Dispositivo construído no DMU 
- Análise de Formabilidade: Através de um software específico, simulações e análises de estampados são efetuadas pela área de Engenharia de Ferramental, o qual é capaz de simular todos os fenômenos físicos que ocorrem durante o processo de produção. Nesta análise é possível identificar e sanar problemas de enrugamento, qualidade da superfície, afinamento e recorte \& flangeamento antes da execução do projeto do ferramental propriamente dito (figura 5.15).

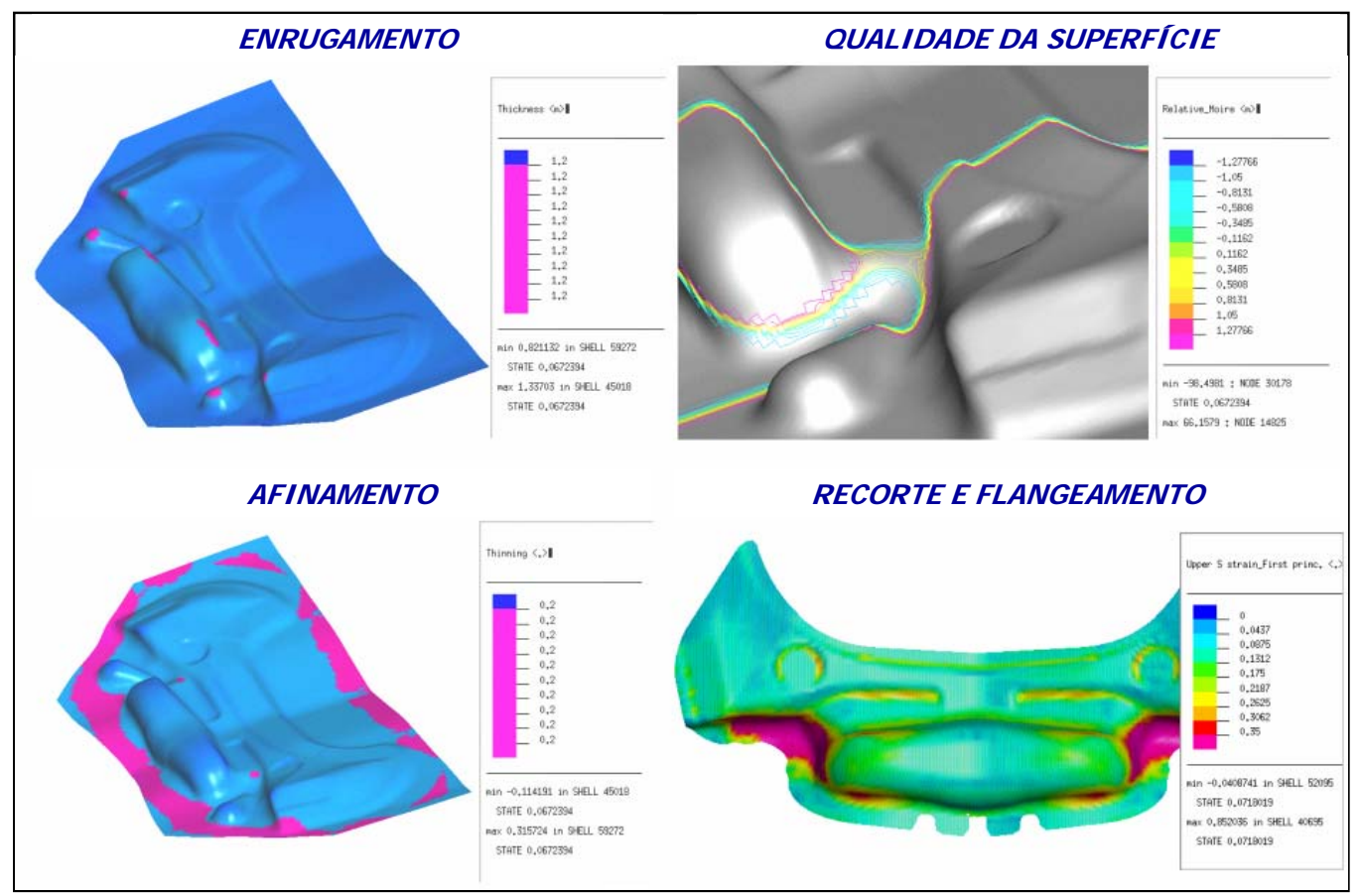

Figura 5.15 - Análise de formabilidade

- Análise de Ruptura de Componentes: Esta análise é realizada pela Engenharia de Ferramental na fase de experiência (try-out) das ferramentas, tendo como objetivo correlacionar a simulação com a realidade, identificando pontos vulneráveis e oportunidades para possíveis reduções de material (blank), além de mudança de especificação de material (figura 5.16). 


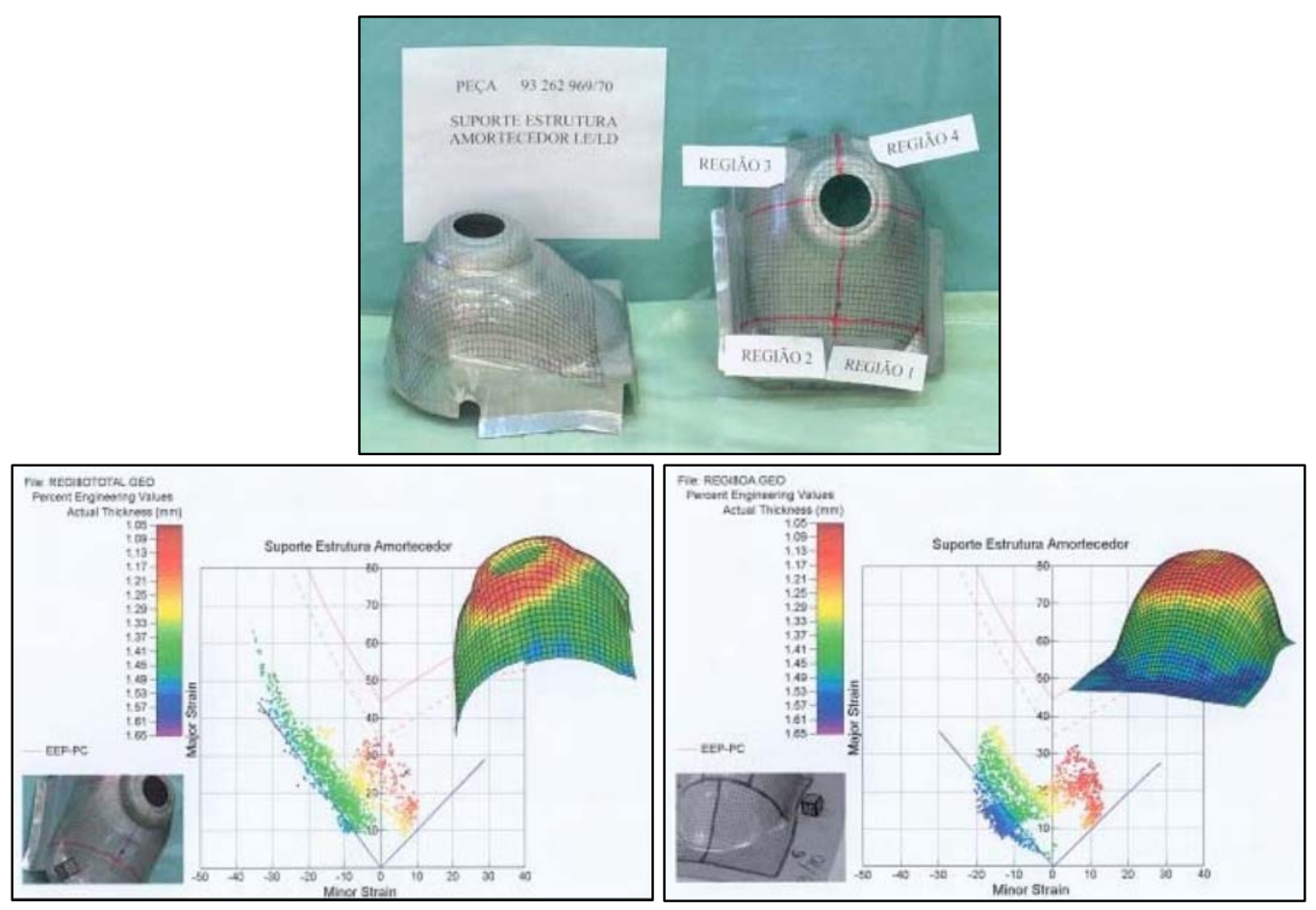

Figura 5.16 - Análise de ruptura de componentes

- Análise Estrutural de Ferramentas: Durante as atividades do projeto do ferramental também é efetuada a análise estrutural de ferramentas através do uso intensivo de simulação numérica, permitindo maior flexibilidade e liberdade para novas idéias e estimulando a criatividade dos engenheiros, resultando em ferramentas mais leves com rigidez otimizada, melhor relação de massa e custo e melhor estabilidade geométrica para os fundidos (figura 5.17). 


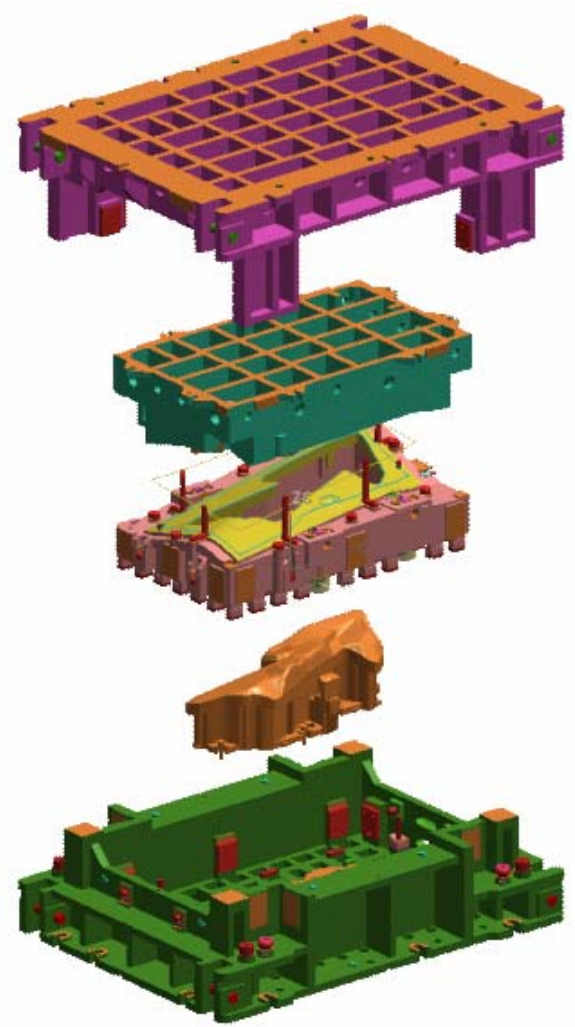

Figura 5.17 - Dispositivo de um ferramental otimizado

Assim como na conceituação do veículo, as ferramentas também são analisadas em uma sala de realidade virtual (figura 5.18) para que todas as pessoas envolvidas na construção e produção possam avaliar em 3D o projeto de um ferramental e identificar melhorias necessárias antes mesmo de ser construído. 


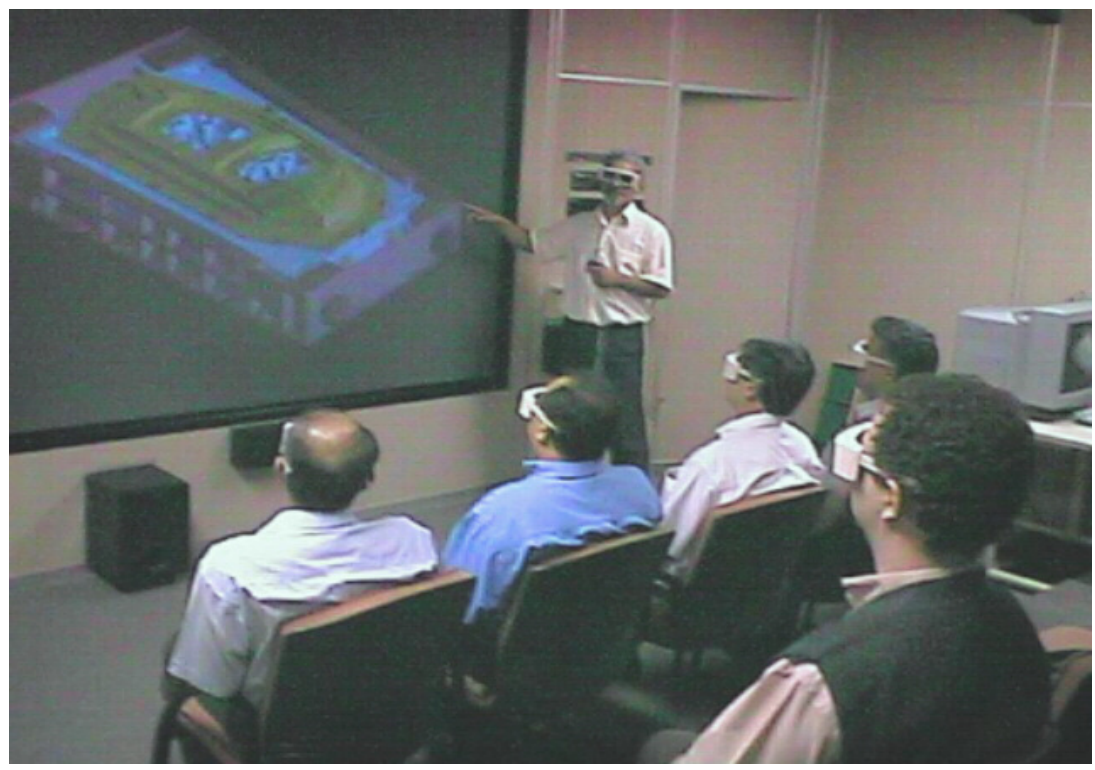

Figura 5.18 - Sala de realidade virtual - Engenharia de Manufatura

- Célula Virtual: A revisão do layout da planta, a identificação de interferências entre equipamentos e a programação de robôs são resultados obtidos a partir da utilização da célula virtual, onde estes parâmetros são utilizados para a instalação de uma célula real como pode se verificado na figura 5.19, no qual mostra um exemplo de instalação da “célula no chão da fábrica” na área da funilaria e sua respectiva célula virtual. Isto propicia um considerável aumento da qualidade dos sistemas de montagem, melhor produtividade, redução de tempo de instalação e de set-up alinhado com a significante redução de custo de instalação e movimentação desses equipamentos. 


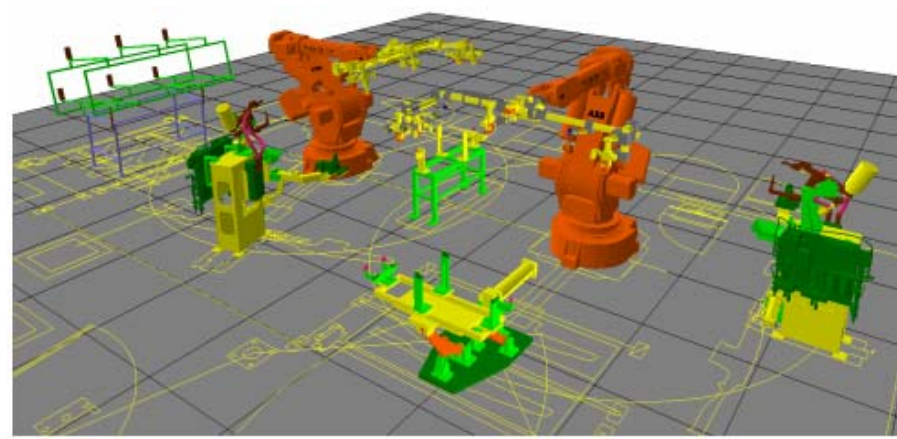

\section{CÉLULA VI RTUAL}

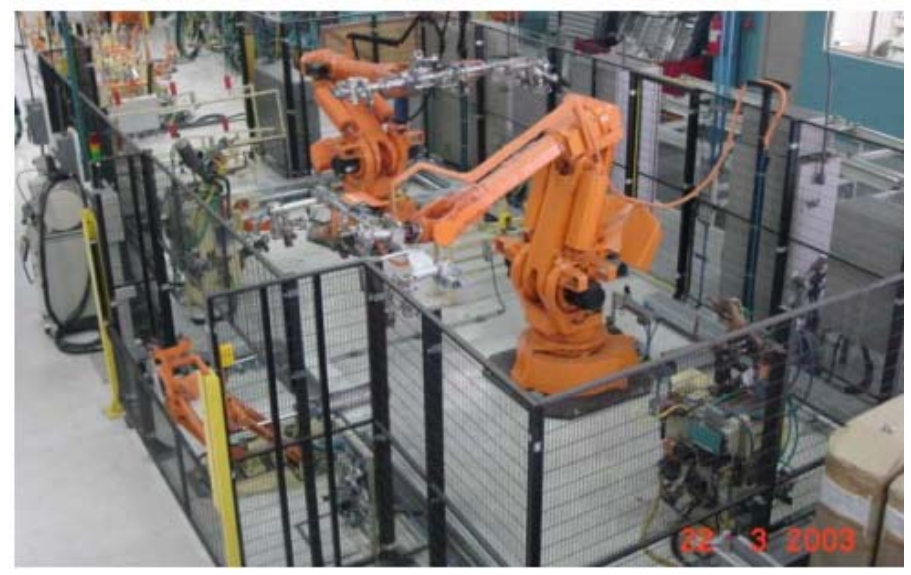

CÉLULA I NSTALADA

Figura 5.19 - Célula virtual X célula instalada

Como resultado de todas as inovações de TI, a área de ferramentaria da GMB, por exemplo, trabalha atualmente sem papel (figura 5.20) e a programação das máquinas é realizada eletronicamente através de CNC’s interligados à área de projeto do ferramental, onde os ferramenteiros estão adequadamente treinados para otimizar a utilização dos recursos digitais disponíveis. 


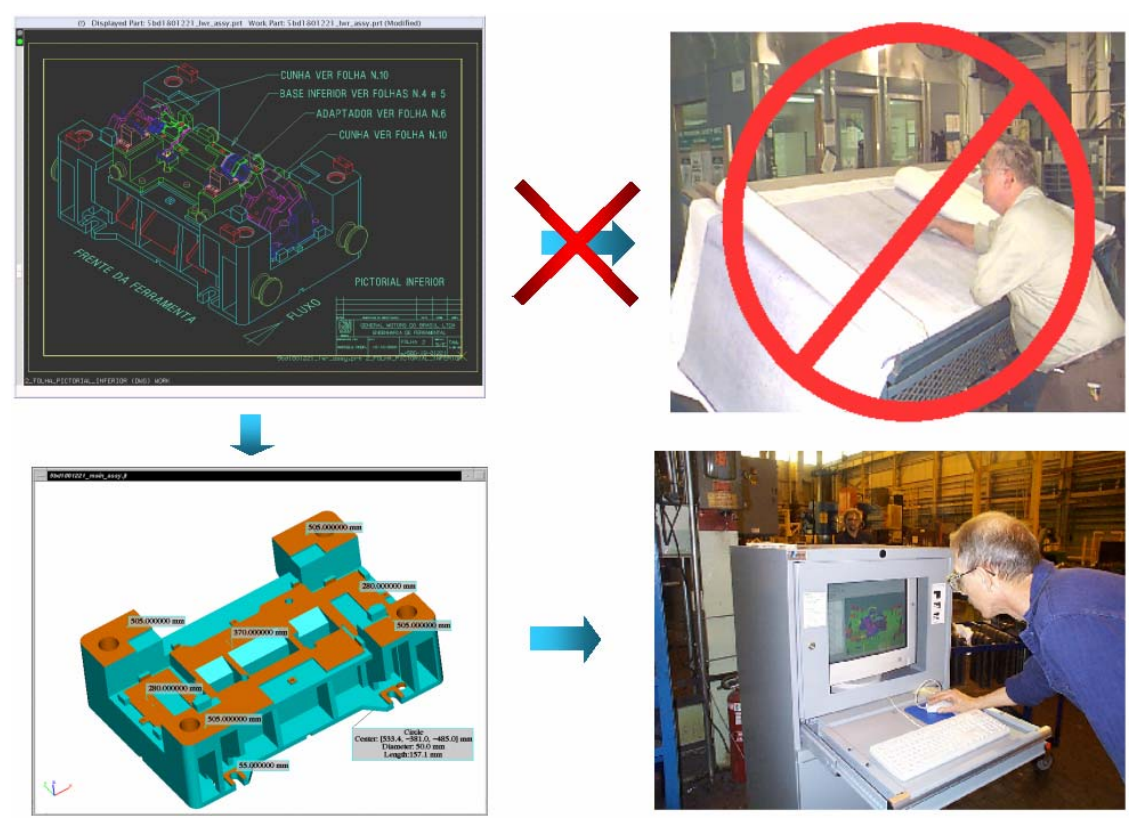

Figura 5.20 - Trabalho sem papel na ferramentaria da GMB

Portanto, no tocante a custos e qualidade, pode-se afirmar que apesar de árduos investimentos em sistemas, equipamentos e treinamentos, o resultado almejado no desenvolvimento de projetos foi alcançado, no qual a utilização de ferramentas virtuais é a base para a tomada de decisões gerenciais, o balanceamento do desempenho do produto e um elemento fundamental para o "Time to Marketing”.

Denota-se, portanto, que a utilização de ambientes virtuais vem sendo uma constante na redução de protótipos físicos e respectivos planejamentos de testes físicos, bem como na prevenção de falhas em fases preliminares do projeto, no qual qualquer alteração necessária é menos onerosa e fácil de ser executada, permitindo também a centralização dos dados em um sistema de gerenciamento único podendo ser compartilhado por toda a organização. Com sistemas globais e integrados, as engenharias podem trabalhar simultaneamente reduzindo o tempo de desenvolvimento total do produto e conseqüentemente o seu custo total. 


\section{ANÁLISE DO ESTUDO DE CASO}

Neste capítulo será apresentada a aplicação do referencial teórico na General Motors do Brasil a fim de verificar onde a TI se posiciona na estrutura e na estratégia da GMB e como o seu uso pode influenciar no desenvolvimento de um veículo. Em outras palavras, como a TI pode contribuir de maneira eficaz para o sucesso ou para a maior competitividade da empresa.

\subsection{Análise quanto ao "Grid Estratégico" e a "Matriz de Intensidade de Informação"}

Analisando o impacto estratégico da TI, segundo o “Grid Estratégico” e a “Matriz de Intensidade de Informação”, percebe-se que a GMB, apesar de atuar no ramo industrial, está totalmente alicerçada na TI, sendo esta parte indissociável da operação e da estratégia da empresa. Pode-se afirmar que, sem a TI, a GMB não tem como desenvolver novos produtos, nem mesmo operar no dias de hoje.

Outro fator importante a ser destacado é a inovação no campo do varejo (vendas/ distribuição), onde a GMB vem cada vez mais realizando suas vendas ao consumidor final pela INTERNET (figura 6.1), o que acarreta uma significativa redução de custos na logística e tempo de entrega do produto ao cliente, sendo uma efetiva ferramenta de vendas. Vale ressaltar que no meio automobilístico a GM do Brasil foi a primeira no mundo a utilizar a Internet como ferramenta de venda de veículos e atualmente é líder em vendas por esta via. 


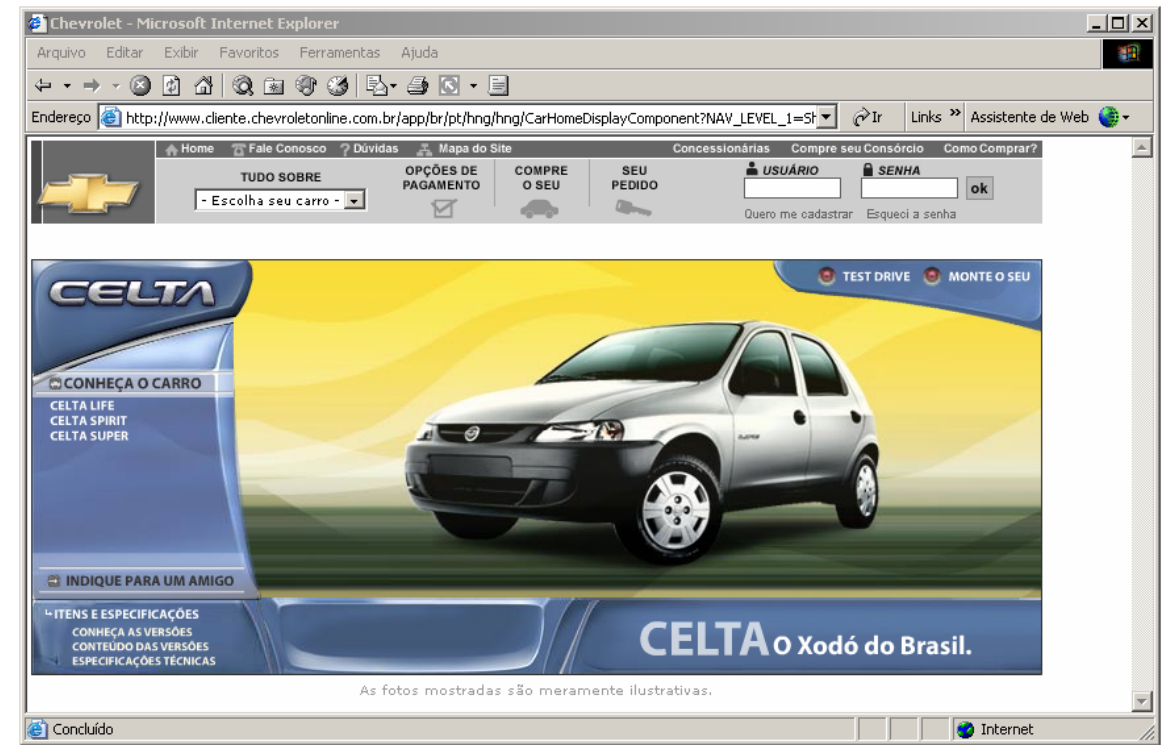

Figura 6.1 - Venda de veículos pela "Internet”

Portanto, analisando “Grid Estratégico” o quadrante "ESTRATÉGICO” é o que melhor combina com sua situação, uma vez que se tem a perspectiva de novas aplicações com impacto estratégico (figura 6.2).

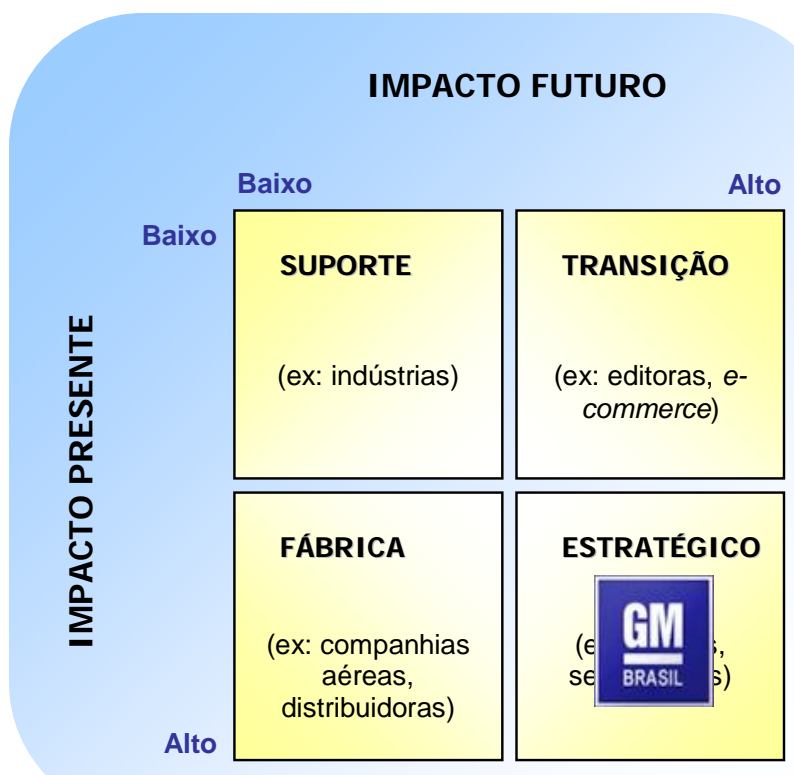

Figura 6.2 - Posição da GMB no "Grid Estratégico" 
Já verificando em relação a "Matriz de Intensidade de Informação”, pode-se concluir que a GMB está posicionada no quadrante "alto conteúdo de informações no produto” e “alta intensidade de informações na cadeia de valor (processo)”, uma vez que a utilização da TI tanto no desenvolvimento do produto pela Engenharia do Produto, bem como no processo pela Engenharia de Manufatura é fortemente evidente conforme relatado no capítulo do Estudo de Caso (figura 6.3).

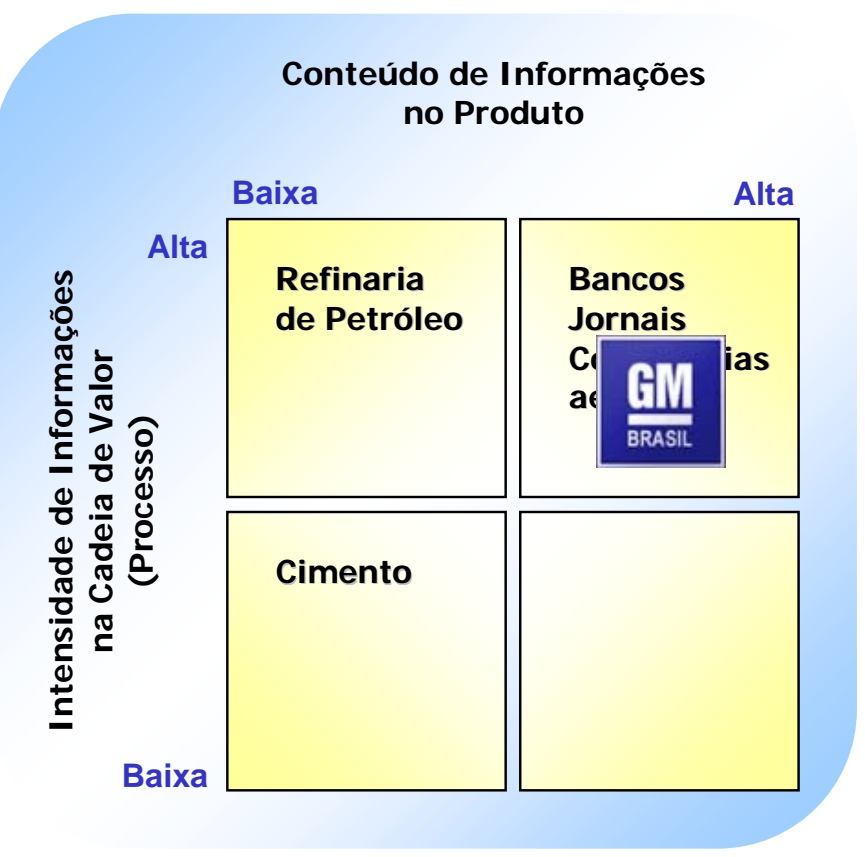

Figura 6.3 - Posição da GMB na "Matriz de Intensidade de Informação”

\subsection{Análise dos "Fatores Críticos de Sucesso"}

No tocante a análise dos "Fatores Críticos de Sucesso" (FCS), foram identificados como fundamentais para a GMB, os seguintes:

\ Ênfase na qualidade;

口 Custos reduzidos;

a Foco no cliente;

๑ Liderança no mercado;

- Novos produtos lançados no time to market estabelecido;

๑ Entrega de veículos ao cliente no prazo. 
Contudo, pode-se verificar que alguns destes FCS já estão sendo alcançados, uma vez que a aplicação da TI no NPD através de análises virtuais e simulações virtuais utilizando o CAD/CAE/CAM, Mock-Ups virtuais, etc, conforme já mencionado anteriormente, garantem a qualidade almejada, a redução de custos bem como a otimização de tempo ainda na fase de desenvolvimento, tendo-se rapidez no lançamento de novos produtos no time to market estabelecido. Pode-se verificar no gráfico abaixo (figura 6.4) a relação crescente da quantidade de mão-de-obra na área responsável pelas análises e simulações virtuais versus a queda de protótipos físicos necessários desde o ano 1996 até os dias de hoje na GMB.

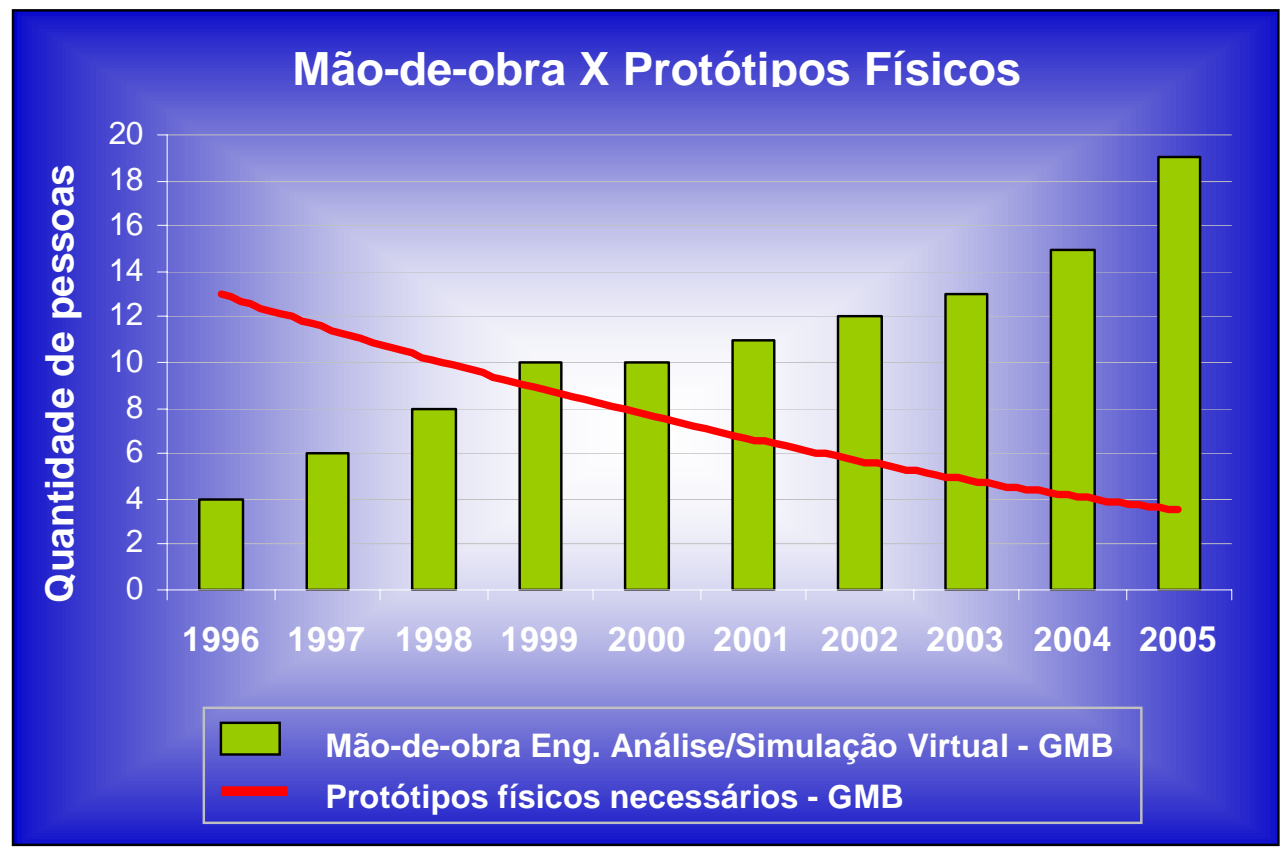

Figura 6.4 - Gráfico: “Mão-de-obra X Protótipos Físicos” - GMB

O uso da INTERNET, conforme também já relatado, também é considerado um fator importante no alcance do último FCS citado, bem como uma linha direta entre a GMB e o cliente, permitindo aproximar-se cada vez mais no foco do cliente, além de impactar beneficamente nas vendas de veículos e, portanto contribuir significativamente no tocante de ser a líder no mercado. 
Portanto conforme mencionado anteriormente, denota-se que a utilização de um processo bem estruturado, no caso o GVDP na GM, aliado a utilização estratégica da TI, resultou em uma redução drástica no tempo do desenvolvimento em aproximadamente 42 semanas, permitindo o desenvolvimento de uma maior gama de produtos nos últimos anos, no qual proporcionou a liderança do mercado atingindo o patamar de 23\% da fatia de mercado no ano de 2004.

\subsection{Análise quanto ao "Alinhamento Estratégico"}

Utilizando-se o "Modelo do Alinhamento Estratégico" de HENDERSON e VENKATRAMAN (1993), pode-se considerar que a GMB vem adotando a perspectiva de “Transformação Tecnológica”, conforme figura 6.5, devido ao fato da busca por novas aplicações de TI, principalmente aquelas baseadas em INTERNET, para permitir uma nova estratégia de atuação mais direta com os clientes. Pode-se citar também a consolidação do uso da Engenharia Simultânea utilizando os recursos da TI, principalmente entre a Engenharia de Produtos e a Engenharia de Manufatura, bem como o desenvolvimento de produtos mais próximos dos fornecedores, utilizando uma comunicação interligada através de Aplicações Paramétricas Integradas (Unigraphics, TcAE - Team center Automotive Edition, VisMockup, etc.), tendo uma atuação mais ampla que a de abastecer com bens físicos, incorporando também a de proporcionar informações/ soluções técnicas e serviços, visando a TI como contribuição de um melhor posicionamento no atual mercado competitivo. 


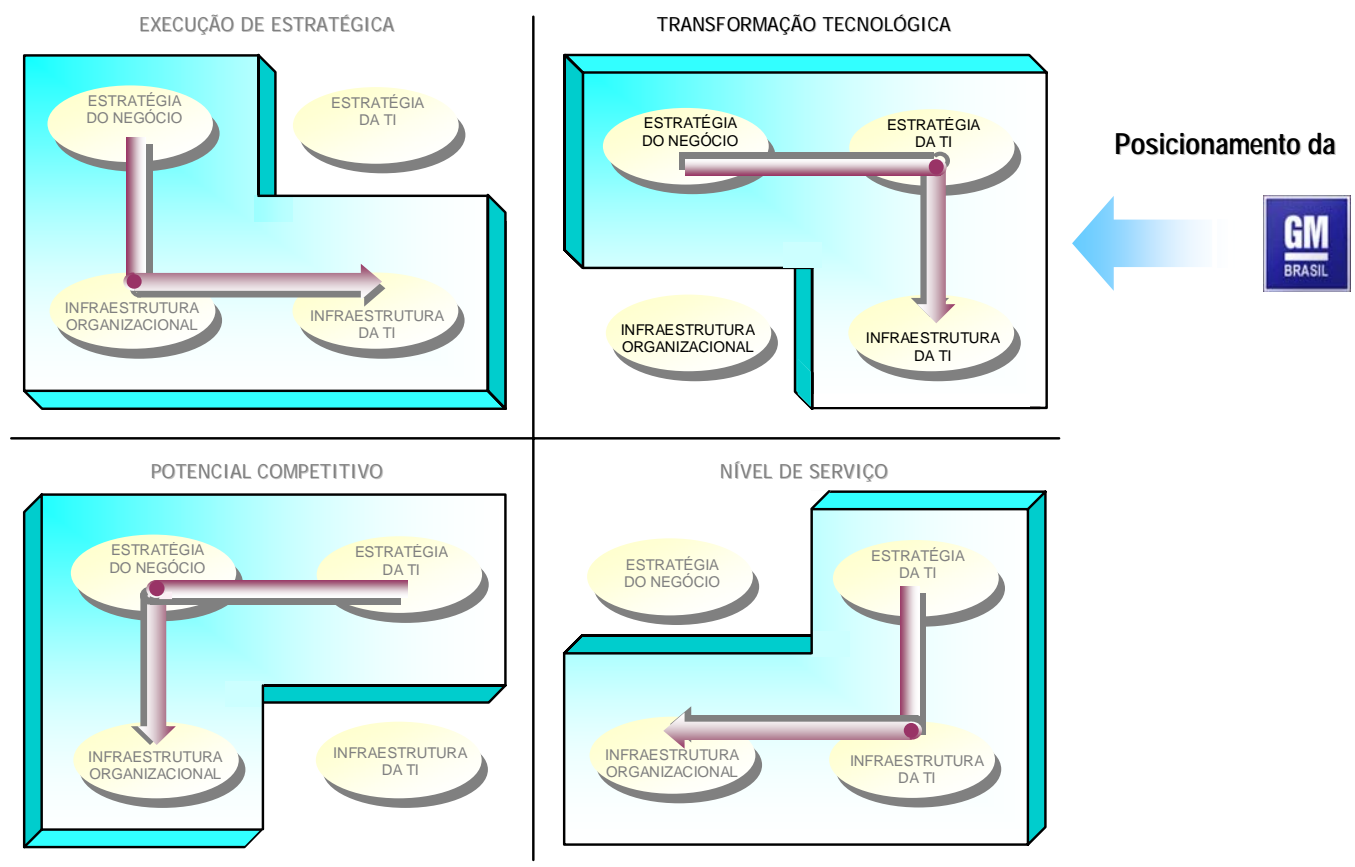

Figura 6.5 - Posição da GMB no "Alinhamento Estratégico”

\subsection{Análise da "Escada de Avaliação"}

A utilização da “Escada de Avaliação” na GMB deve ter seu foco baseado na análise de aplicações de TI específicas. Face ao considerável número de aplicações e suas respectivas interfaces existentes, foram determinados dois exemplos específicos de caráter relevante e residente no ambiente de desenvolvimento de produtos.

Como primeiro exemplo para esta análise, optou-se pela aplicação da TI na Engenharia de Análise Estrutural. Sendo esta engenharia hoje um dos elementos principais no NPD de modo a garantir o desenvolvimento de veículos otimizados no tocante à segurança veicular, ciclo de vida dos componentes, comportamento aerodinâmico, fluídico e térmico, onde se pode classificar o conjunto de softwares que formam esta aplicação de TI como pertence ao degrau 7, "SISTEMA ESTRATÉGICO”, resultando em uma considerável vantagem competitiva em termos de economia de tempo e confiabilidade nas simulações virtuais, aprimorando, portanto, a confiabilidade e a qualidade do projeto no NPD com a introdução destes novos métodos de trabalho. 
Para o segundo exemplo, a aplicação do DMU (Digital Mock-Up) foi escolhida, pois passou a ter uma ênfase no NPD tão importante quanto ou até maior do que a própria área de montagem física de protótipos. O nível de precisão apresentado nos resultados, principalmente nas montagens iniciais do projeto, passou a ser extremamente importante para se evitar que erros significativos fossem cometidos durante a montagem física, gerando impactos consideráveis em termos de custos, tempo e qualidade, conforme mencionado no item 5.2 deste trabalho. Devido a isso, a aplicação do DMU deve ser classificada no degrau 3 da escada de avaliação, “SISTEMAS DE VALOR ADICIONADO DIRETO”, devido a proporcionar um real valor adicionado direto ao negócio. Embora a utilização do DMU não proporcione diretamente um aumento na fatia de mercado, considerar esta aplicação como um sistema de valor adicionado direto, demonstra-se adequada em sua classificação. 


\section{CONCLUSÕES}

Primeiramente, pode-se dizer que o objetivo deste trabalho foi alcançado, uma vez que ele permitiu mostrar que a aplicação da TI no processo do NPD pode proporcionar vantagens significativas em termos de melhoria da qualidade, redução de custo e na otimização de tempo no desenvolvimento. Dentro desta perspectiva, o estudo apresentado confirma a contribuição da utilização da TI na Engenharia do Produto. Além disso, foi possível notar os impactos positivos do uso da TI na General Motors do Brasil como um todo, integrando as diversas áreas envolvidas de forma a facilitar o planejamento, a execução e a coordenação de um projeto, garantindo a qualidade das informações necessárias.

Deve-se periodicamente analisar a eficácia da TI mantendo um processo contínuo, no qual as ferramentas apresentadas como FCS, o “Grid Estratégico” e o “Modelo do Alinhamento Estratégico”, devem ser constantemente ajustadas conforme necessário, para acomodar modificações na estratégia da organização, no ambiente ou na estrutura organizacional. Estas alterações são importantes não somente por si só, mas também por indicar os rumos da organização, pois os sistemas de informação dever ser sempre analisados sob o prima de sua adequação no contexto da organização, tanto nas suas operações como nos objetivos estratégicos.

Analisando as perguntas formuladas no item 1.3 deste trabalho, referente aos anseios e perspectivas da TI, elas podem ser respondidas conforme a seguir:

口 “Como a TI pode apoiar o processo de desenvolvimento de produtos?”

A TI apóia diretamente o processo de desenvolvimento de produtos através de suas inúmeras aplicações, como, por exemplo, as ferramentas de análise e simulação virtuais que, além de incorporar ao produto um grau de exatidão elevado em seus resultados, representando maior qualidade agregada ao produto, também proporcionam uma significativa redução do tempo de desenvolvimento dos mesmos. 
口 "Por que o desenvolvimento de produtos é importante para a indústria automobilística?”

O desenvolvimento de produtos se tornou um elemento essencial e estratégico para o sucesso de um veículo no mercado, pois as indústrias automobilísticas descobriram que, ao se concentrar esforços durante a fase do $\mathrm{NPD}$, as oportunidades de melhoria do produto no tocante à qualidade e custos, proporcionam resultados significativos que serão traduzidos em números de vendas. Porém, cabe ressaltar que não é suficiente se ter um NPD implementado, mas sim executá-lo de maneira disciplinada por todos os envolvidos.

口 “Como a TI pode influenciar no parâmetro Tempo no desenvolvimento de um veículo?”

Esta questão foi respondida em sua total abrangência no item 5.1 deste presente trabalho, onde resumidamente se pode afirmar que a TI vem proporcionando uma considerável redução no tempo de desenvolvimento de um veículo, ou seja, evoluindo de um processo que demandava cerca de 60 meses no início da década de 90 para aproximadamente 20 meses nos dias atuais, o que representa um terço do tempo apenas.

- “Como as variáveis Qualidade e Custo podem ser influenciadas pela TI?”

A variável “Qualidade”, conforme até citado na resposta para a primeira pergunta, bem como no item 5.2 deste trabalho, se deve ao fato da TI proporcionar, através de suas ferramentas, uma exatidão maior nos resultados dos cálculos para um projeto, evitando se trabalhar com grandes coeficientes de segurança ou tolerâncias. Já o “Custo” pode ser respondido em relação a um dos principais e mais notáveis fatores, ou seja, o da redução da necessidade do número de protótipos físicos em detrimento do uso de 
protótipos virtuais, o que proporciona uma economia considerável em um projeto.

Com relação às proposições que puderam ser formuladas no início deste trabalho, citadas especificamente no item 4.3, tem-se:

1. A TI é um importante recurso para o NPD, no qual esta tem basicamente a função de armazenamento eficaz das informações através de bancos de dados.

Para esta primeira proposição, verifica-se que a TI é extremamente importante no processo do NPD, seja para a GM ou qualquer outra empresa, porém, a TI não se limita, de forma alguma, somente à função de armazenamento eficaz das informações. Ela também tem assumido um papel comprovadamente de recurso estratégico para as empresas quando ela é aplicada sob a forma de ferramentas para análises e simulações virtuais, colaborando, inclusive, diretamente na tomada de decisões gerenciais e na prevenção de possíveis falhas em uma fase preliminar do projeto. Uma explanação mais abrangente sobre estas características pode ser encontrada no capítulo 5 deste presente trabalho. Portanto, esta proposição pode ser interpretada de forma a estar parcialmente confirmada em sua colocação.

2. Cada vez mais a aplicação da TI sob a forma de ferramentas como CAD/CAE/CAM no processo do NPD tem-se demonstrado estrategicamente vital para as indústrias automobilísticas.

Com relação a esta segunda proposição, é facilmente perceptível a contribuição da aplicação da TI nestas áreas de CAD/CAE/CAM, sob o ponto de vista de proporcionar significativos ganhos em termos de economia de tempo e redução dos custos de desenvolvimento em um projeto. É certo de que os investimentos em TI para estas áreas são, a princípio, relativamente elevados, porém, sua aplicação acaba por ser amortizada comprovadamente 
no médio e longo prazo. É importante citar que uma outra importante vantagem da aplicação da TI nestas áreas é a comunicação direta de dados entre estes três sistemas, interagindo de forma abrangente e compatível, e não como sistemas remotos e sem interface. Sendo assim, esta proposição deve ser entendida como confirmada, podendo ser encontrado no capítulo 5 deste trabalho, uma breve comprovação desta afirmação.

3. A TI pode gerar impacto estratégico mesmo em indústrias mais tradicionais, como o setor de manufatura.

E por fim, para esta última proposição mencionada, cabe aqui a reprodução parcial do que fora dissertado no item 6.1, como segue: “...percebe-se que a GMB, apesar de atuar no ramo industrial, está totalmente alicerçada na TI, sendo esta parte indissociável da operação e da estratégia da empresa. Pode-se afirmar que, sem a TI, a GMB não tem como desenvolver novos produtos, nem mesmo operar no dias de hoje”. Portanto, não se faz mais necessária nenhuma colocação para se poder afirmar que esta proposição confirma na íntegra a sua colocação.

Cabe ressaltar que, se hoje a GMB tem um GVDP mais estruturado e uma alta tecnologia disponível à seus usuários, isto se deve a severos investimentos em equipamentos e sistemas, bem como treinamentos dedicados, focando uma conscientização da importância da aplicação disciplinada do GVDP como um processo estratégico, no qual provocaram mudanças significativas na forma de trabalho à medida que ferramentas foram sendo implementadas como o UG, o Digital Mock-Up, a própria INTRANET e INTERNET, no qual sem sair do seu posto de trabalho, pode-se até mesmo realizar reuniões utilizando softwares como o Netmeeting, agregando novas tarefas em função das tecnologias adotadas.

Outro exemplo da aplicação da TI que vem proporcionar resultados significativos em termos de facilidade, rapidez e foco na pesquisa de dados são os bancos de dados compartilhados disponíveis no ambiente de INTRANET da GM. A 
principal vantagem, é a de que toda e qualquer informação disponível em um destes bancos de dados pode ser acessada de qualquer computador que esteja conectado à rede interna da GM, além de possuir níveis de acesso personalizados de acordo com cada usuário cadastrado e autorizado para o acesso, garantindo também a segurança e rastreabilidade da consulta às informações. A certeza de que o usuário está consultando sempre a informação correta e a mais atualizada também é um fator de garantia da qualidade da informação disponível.

Existem centenas de bancos de dados corporativos dentro do ambiente de Engenharia, dentre os quais, se pode citar três exemplos para referência:

- Informações sobre o planejamento de construção de protótipos, indexado respectivamente por cada protótipo, pela fase de desenvolvimento, e seu projeto;

- Informações sobre aplicação de práticas de sucesso recomendadas, indexadas por tipo de peça e tipo de aplicação;

- Informações sobre modificações do produto, indexadas pelo projeto, pelo custo, e pelo tempo de implementação.

É importante citar que cada banco de dados desse, deve possuir um responsável pela qualidade, atualização e segurança das informações disponibilizadas, bem como avaliar criteriosamente cada requisição de acesso solicitada por algum usuário pretendente.

Ao longo deste trabalho foi amplamente discutido a importância e as vantagens de testes virtuais, porém também é importante ressaltar que o veículo simulado no computador somente tem aquilo que é incluído no programa e, portanto, a melhor simulação é inferior a natureza real, onde basicamente se trata de uma simplificação controlada da situação real, no qual, por enquanto, nada sai do computador diretamente para a linha de montagem, onde os protótipos físicos são essenciais para, no mínimo, conferir se o projeto planejado. 
Como futuras implementações a GMB pretende utilizar a aplicação do Voice Over IP (VOIP), onde sua implementação dará início pela Engenharia do Produto, com o objetivo primordial de proporcionar significativas reduções de custo estrutural, uma vez que, devido à tendência cada vez maior do desenvolvimento de projetos globais, a quantidade de ligações internacionais tem se tornado uma constante no NPD, onde o uso desta aplicação torna-se economicamente viável.

Finalizando, conclui-se que a integração da TI no NPD vem revolucionando o ambiente automobilístico. Contudo, de nada valeria se não houvesse uma alta direção compromissada nos objetivos e metas, incentivando as pessoas envolvidas no processo, sendo um fator determinante a consciência da importância de se utilizar todos os recursos disponíveis para se obter o sucesso almejado do projeto, como é o caso da GMB.

Como tema para futuros trabalhos, destaca-se a análise do comportamento e o progresso da TI no tocante à atuação da GMB como um dos pólos mundiais de desenvolvimento de plataformas globais. Este título de responsabilidade ímpar para a divisão brasileira exigirá ações de maior envergadura relativa à criação e padronização de processos, total compatibilidade e integração entre os sistemas, exigindo, portanto, o estabelecimento de uma nova cultura e disciplina necessárias para se atuar desta maneira. Provavelmente a análise da TI quanto à eficiência e eficácia deverá indicar que a GMB estará nivelada com os outros pólos de desenvolvimento, bem como também com as divisões espalhadas pelo mundo, que passarão a ser clientes dos projetos da GMB.

Outro tema importante a ser investigado em futuras pesquisas seria a oportunidade de se poder avaliar outras indústrias automobilísticas sob o mesmo foco que foi analisado a GMB, de modo a se poder traçar um comparativo entre elas, destacando similaridades de aplicação da TI do ponto de vista estratégico, seus pontos fortes e fracos, bem como seus pontos distintivos e as razões para serem diferentes em aspectos específicos da TI. 


\section{REFERÊNCIAS BIBLIOGRÁFICAS}

- ALliPRANDINI, D. H.; ROZENFELD, H.; VALERI, S. G. “Análise do processo de desenvolvimento de produtos de uma indústria do setor automobilístico”. In: II Congresso Brasileiro de Gestão de Desenvolvimento de Produto, São Carlos - SP, 2000. Anais. São Carlos, 30-31 Ago 2000. p.163-170.

- AMARAL, D. C. Colaboração cliente-fornecedor no desenvolvimento de produto: integração, escopo e qualidade do projeto do produto - estudos de caso na indústria automobilística brasileira. São Carlos - SP, 1997. 195p. Dissertação (Mestrado) - Departamento de Engenharia de Produção, Universidade Federal de São Carlos.

- ANTHONY, M. T.; MCKAY, J. "Balancing the product development process: achieving product and cycle-time excellence in high-technology industries.” Journal of Product Innovation Management, v.9, n.2, p.140147, June 1992.

- BACON, G.; BECKMAN, S.; MONERY, D.; WILSON, E. "Management product definition in high-technology: a pilot study.” California Management Review, v.6, n.3, p.32-56, 1994.

- BENBASAT, I.; GOLDSTEIN, D. K.; MEAD, M. "The case research strategy in studies of information systems.” Management Information Systems Quarterly, v.11, n.3, p.369-386, September 1987.

- BOYNTON, A. C.; ZMUD, R. W. “An assessment of critical success factors”. Sloan Management Review, v.25, n.4, p.17-27, Summer 1984. 
- BROWN, S. L .; EISENHARDT, K. M. "Product development: past research, present findings, and future directions.” Academy of Management Review, v.20, n.2, p.343-378, 1995.

- BRYNJOLFSSON, E.; HITT, L. M. "Beyond the productivity paradox.” Communications of the ACM, v.41, n.8, p.49-55, 1998.

- CARR, N. G. “It doesn’t matter.” Harvard Business Review, v.81, n.5, p.4149, May 2003.

- CASH Jr, J. I.; KONSYNSKI, B. R. "IR redraws competitive boundaries.” Harvard Business Review, v.63, n.2, p.134-142, Mach/April 1985.

- CATELLI, A. "Measuring the value chain by opportunity costs" In: Fifth International Seminar on Manufacturing Accounting Research, Pisa, 2001. Anais. Pisa - Italy: EIASM, June 2001. v.1, p.1-19.

- CLARK, K. B.; FUJIMOTO, T. Product development performance strategy, organization and management in the world auto industry. Boston - MA, Harvard Business School Press, 1991.

- CLAVER, E.; GONZÁLEZ, R; LLOPIS, J “An analysis of research in information systems (1981-1997).” Information \& Management, v.37, n.4, p.181-195, June 2000.

- CLEMONS, E. K.; McFARLAN, W. F. “Telecom: hook up or lose out.” Harvard Business Review, v.64, n.4, p.91-97, July/August 1986.

- CUSUMANO, M.; NOBEOKA, K. "Strategy, structure and performance in product development: Observations from the auto industry.” Research Policy, v.21, n.3, p.265-293, June 1992. 
- DAVENPORT, T. H. Reengenharia de processos: como inovar na empresa através da tecnologia da informação. Editora Campus, Rio de Janeiro, 1994.

- DAVENPORT, T. H.; HAMMER, M.; METSISTO, T. J. "How executives cam shape their company's information systems.” Harvard Business Review, v.67, n.2, p.130-142, Mach/April 1989.

- DOYLE, J. R. "Problems with strategic information systems frameworks". European Journal of Information Systems, v.1, n.4, p.273-280, 1991.

- ETHOS INSTITUTO DE PESQUISA. Brasil, 2004. Conheça a diferença entre a pesquisas quantitativas e qualitativas. Disponível em $<$ http://www.ethos.com.br/diferenciais/quantitativa_qualitativa.htm>. Acesso em 20 de mar. 2005.

- FARBEY, B.; LAND, F. F.; TARGETT, D. “A taxonomy of information systems applications: the benefits' evaluation ladder”. European Journal of Information Systems, v.4, n.1, p.41-50, March 1985.

- FARREL, D. “The real new economy.” Harvard Business Review, v.81, n.10, p.104-112, October 2003.

- FLORENZANO, M. C. Gestão do desenvolvimento de produtos: estudo de casos na indústria brasileira de autopeças sobre divisão de tarefas, capacidade e integração interunidades. São Carlos - SP, 1999. 135p. Dissertação (Mestrado) - Departamento de Engenharia de Produção, Universidade Federal de São Carlos.

- GODOY, A. "Introdução à pesquisa qualitativa e suas possibilidades." Revista de Administração de Empresas, v.35, n.2, p.57-63, Março/Abril 1995. 
- GRIFFIN, A. "PDMA research on new product development practices: updating trends and benchmarking best practices.” Journal of Product Innovation Management, v.14, n.6, p.429-458, November 1997.

- HARTLEY, J. F. “Case studies in organizational research.” In: CASSELL, C.; SYMON, G. Qualitative methods in organizational research: a practical guide. London: Sage, 1994. p.208-229.

- HENDERSON, J. C.; VENKATRAMAN, N. "Strategic alignment: leveraging information technology for transforming organizations”. IBM Systems Journal, v.32, n.1, p.4-16, 1993.

- JOHNE, F. A.; SNELSON, P. A. "Success factors in product development: a selective review of the literature." Journal of Product Innovation Management, v.5, n.2, p.114-128, June 1988.

- KAMINSKI, P. C. Desenvolvendo produtos com planejamento, criatividade e qualidade. Editora Livros Técnicos e Científicos, Rio de Janeiro, 2000.

- LAURINDO, F. J. B. Um estudo sobre a avaliação da eficácia da tecnologia da informação nas organizações. São Paulo, 2000. 176p. Tese (Doutorado) - Departamento de Engenharia de Produção, Universidade de São Paulo.

- LAURINDO, F. J. B. C. "Tecnologia da informação como suporte às estratégias empresariais”. Relatório parcial de pesquisa. Departamento de Engenharia de Produção da Escola Politécnica da Universidade de São Paulo, 2001. Disponível em: $<$ http://www.prd.usp.br/redecoop/TI estrat BAH FJBL format.PDF $>$. Acesso em: 20 de Maio 2003. 
- LAURINDO, F. J. B. Tecnologia da Informação: Eficácia nas Organizações. Editora Futura, São Paulo, 1ª Edição, 2002.

- LAURINDO, F. J. B.; CARVARLHO, M. M. “Technology enhancing new product development in a Brazilian company.” In: Euroma 2002 - European Operations Managemente Association - 9 th. Internaitonal Annual Conference: "Operations Management and the New Economy", Copenhagen, Dinamarca, 2002. Proceedings. Copenhagen, Dinamarca, 2 - 4 June 2002, p.843-854.

- LAURINDO, F. J. B.; CARVALHO, M. M. “Changing product development process through information technology: a Brazilian case.” Journal of Manufacturing Technology Management, v.16, n.3, p.312-327, 2005.

- LEVY, M.; LOEBBECKE, C.; POWELL, P. "SMEs, co-operation and knowledge sharing: the role of information systems.” European Journal of Information Systems, v.12, p.3-17, 2003.

- LEWIS, P. R.; LUFTMAN, J. N.; OLDACH, S. H. "Transforming the enterprise: the alignment of business and information technology strategies”. IBM Systems Journal, v.32, n.1, p.198-221, 1993.

- MAcCORMACK, A.; VERGANTI, R.; IANSITI, M. "Developing products 'internet time': the anatomy of a flexible development process.” Management Science, v.47, n.1, 13p, 2001.

- MAHAJAN, V.; WIND, J. "New product models: practice, shortcomings and desired improvements.” Journal of Product Innovation Management, v.9, n.2, p.128-139, June 1992. 
- MANNING, P. K. "Metaphors of the field: varieties of organizational discourse.” Administrative Science Quarterly, v.24, n.4, p.660-671, December 1979.

- MARCOVITCH, J. Tecnologia da informação e estratégia empresarial. São Paulo, 1996. 116p. Monografia (Graduação) - Faculdade de Economia Administração e Contabilidade, Universidade de São Paulo.

- McFARLAN, W. F. "Information technology changes the way you compete”. Harvard Business Review, v.62, n.3, p.98-103, May/June 1984.

- MENDES, C. D. "Informática e competitividade da empresa”. In: XX Congresso Nacional de Informática, São Paulo, 1987. Anais. São Paulo: SUCESU, 1987. p.175-180.

- NOLAN, R. L. "Managing the crises in data processing”. Harvard Business Review, v.57, n.2, p.115-126, March/April 1979.

- PORTER, M. E. "How competitive forces shape strategy." Harvard Business Review, v.57, n.2, p.137-145, March/April 1979.

- PORTER, M. E. Competitive Advantage. The Free Press, New York, $10^{\mathrm{a}}$ ed., 1985.

- PORTER, M. E. “Strategy and the Internet.” Harvard Business Review, v.79, n.2, p.63-78, March/April 2001.

- PORTER, M. E.; MILLAR, V. E. "How information gives you competitive advantage.” Harvard Business Review, v.63, n.4, p.149-160, July/August 1985. 
- PUGH, S. Creating innovative products using total design: the living legacy of Stuart Pugh. Addison-Wesley Publishing Company, Massachusetts, 1996.

- ROCKART, J. F. "Chief executives define their own data needs”. Harvard Business Review, v.57, n.2, p.81-93, Mach/April 1979.

- SILVA, S. L. Estratégia e desempenho no desenvolvimento de produtos na indústria automobilística brasileira. São Carlos - SP, 1995. 215p. Dissertação (Mestrado) - Departamento de Engenharia de Produção, Universidade Federal de São Carlos.

- TOLEDO, J. C. Gestão da mudança da qualidade de produto. São Paulo, 1994. 231p. Tese (Doutorado) - Departamento de Engenharia de Produção, Universidade de São Paulo.

- TORRES, N. A. Planejamento de Informática na Empresa. Editora Atlas, São Paulo, $1^{\text {a }}$ Edição, 1989.

- WHEELWRIGTH, S. C.; CLARK, K. B. Revolutionizing product development: quantum leaps in speed, efficiency and quality. The Free Press, New York, 1992.

- YIN, R. K. Case Study Research: Design and Methods. Sage Publications, Newbury, 2nd ed., 1994. 